\title{
ADERÊNCIA BACTERIANA E FORMAÇÃO DE BIOFILME AOS FIOS DE DERMOSSUSTENTAÇÃO FACIAL
}

Dissertação de mestrado apresentada ao Programa de PósGraduação Interunidades em Bioengenharia - Escola de Engenharia de São Carlos / Faculdade de Medicina de Ribeirão Preto / Instituto de Química de São Carlos da Universidade de São Paulo como parte dos requisitos para a obtenção do título de mestre em Bioengenharia.

Área de Concentração: Bioengenharia

Orientador: Prof. ${ }^{\text {a }}$ Dr. ${ }^{.}$Elisabeth Loshchagin Pizzolitto 
Dedicatórias 
"Aos meus pais, que me ensinaram a viver com dignidade, que se deram por inteiro e, em muitas vezes renunciaram a seus sonhos para a realização do meu; pelo amor, carinho, pelos sorrisos, pelas lágrimas compreendidas e amenizadas, por toda a atenção, dedicação e apoio ..."

'A minha família, ao meu irmão e a minha cunhada, pela presença e companfia, por sempre estarem ao meu lado, nunca dispensando carinfo e sempre expressando grande amor...Por todo o tipo de ajuda e apoio dedicado para que fosse completa a realização deste sonho em minha vida..." 
'Aos meus amigos, pelo tempo compartilhado, pelo estímulo, carinho e compreensão e, que de alguma forma contribuíram para o êxito desta conquista... Juntos, aprendemos, trabalhamos e conquistamos..."

'A Profa Dra Elisabeth Loshchagin Pizzolitto, minha orientadora, pela atenção, por toda a dedicação, todo o apoio, pela paciência e amizade. Obrigada pela disponibilidade e confiança, para que mais este sonho e projeto em minha vida fosse cumprido..." 
Agradecimentos 
$\mathcal{A}$ Deus, por estar presente em todos os momentos de minha vida, me capacitando para que mais esta etapa fosse concretizada; enchendo-me de alegria em momentos que me pareciam escuros $e$ tristes; me trazendo a tua paz em momentos de ansiedade e preocupação... Deus obrigada porque eis que mais um propósito se cumpre.

Aos funcionários, técnicos e amigos do laboratório de

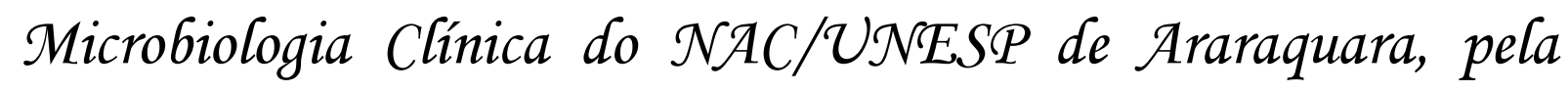
convivência, paciência, e que contribuíram para o êxito deste trabalho.

A Poliquil Araraquara Polímeros Químicos Ltda, pela doação dos fios de poliuretano utilizados neste trabalho, pela atenção, apoio e confiança. 
Ao responsável técnico da microscopia eletrônica de varredura (Instituto de Química, UNESP, Araraquara), por todo o tempo dedicado e atenção dispensada.

A todos os professores e funcionários do Programa de PósGraduação Interunidades em Bioengenharia - USP, São Carlos, pelo apoio, auxílio e incentivo dedicado no decorrer deste trabalho.

A todos os professores, técnicos e funcionários da faculdade de Ciências Farmacêuticas - VNESP, Araraquara, pela ajuda dispensada.

A todos que contribuíram de alguma forma direta ou indiretamente para a realização deste trabalho...

Muito O6rigada!!! 


\section{RESUMO}

LEITE, B.A. Aderência bacteriana e formação de biofilme aos fios de dermossustentação facial. 2008. 121f. Dissertação (Mestrado em Bioengenharia). Programa de Pós-Graduação Interunidades em Bioengenharia - EESC/ FMRP/ IQSC da Universidade de São Paulo, São Carlos, 2008.

A flacidez e as rugas de expressão podem ser amenizadas com lifting facial ou implante no tecido subcutâneo da face de fios de poliuretano ou polipropileno. Sob determinadas condições microrganismos podem aderir sobre os fios e interagir com essas superfícies iniciando crescimento celular. $O$ objetivo do presente estudo foi avaliar a aderência bacteriana aos fios de poliuretano e polipropileno por meio de microscopia eletrônica de varredura e métodos microbiológicos. Os fios foram seccionados em segmentos de $1,0 \mathrm{~cm}$ de comprimento e transferidos individualmente para tubos Falcon $(50,0 \mathrm{ml})$ contendo caldo Mueller Hinton $(15,0 \mathrm{ml})$, com $200 \mu \mathrm{l}$ da suspensão bacteriana $\left(10^{8} \mathrm{UFC} / \mathrm{ml}\right)$ preparada e, incubados por $1 \mathrm{~h}$ e 30 minutos, 4 , 24, 48, 72 e 120 horas. Após cada período de incubação, os corpos-de-prova foram lavados três vezes e introduzidos, separadamente, em $5,0 \mathrm{ml}$ de solução salina esterilizada, sonicados a $40 \mathrm{kHZ}$ por 8 minutos e homogeneizados em vortex por 10 segundos. Esta solução foi diluída (1/10 a 1/1000), da diluição 1/1000 uma alíquota de $0,1 \mathrm{ml}$ foi plaqueada sobre Tryptic Soy Agar (TSA). As placas foram incubadas a $37^{\circ} \mathrm{C}$ por 18 a 24 horas. Após o período de incubação, as células viáveis foram contadas e o resultado anotado em termos de unidades formadoras de colônia (UFC/ml). Os corpos-de-prova destinados à observação por microscopio eletrônico de varredura foram fixados em glutaraldeído, desidratados em séries de álcool, secos em centrífuga a vácuo e metalizados com ouro. A avaliação quantitativa do crescimento de $S$. aureus sobre a superfície do poliuretano, após 1 hora e 30

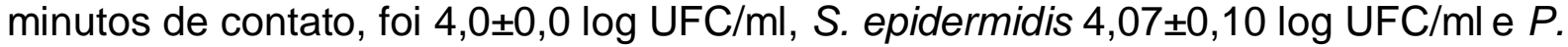
aeruginosa $5,08 \pm 0,1410 \mathrm{log} U \mathrm{FC} / \mathrm{ml}$. Após 4 - 120 horas o número de células viáveis de $S$. aureus sobre a superfície do poliuretano foi $5,49 \pm 0,04 \mathrm{log} U F C / \mathrm{ml}, S$. epidermidis $4,99 \pm 0,07 \mathrm{log} \mathrm{UFC} / \mathrm{ml}$ e $P$. aeruginosa $6,52 \pm 0,03 \mathrm{log} \mathrm{UFC} / \mathrm{ml}$. A avaliação quantitativa do crescimento de $S$. aureus sobre a superfície do polipropileno, após 1 hora e 30 minutos de contato, foi 4,24 $30,20 \mathrm{UFC} / \mathrm{ml}, S$.

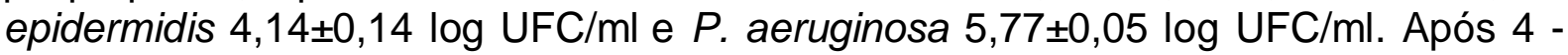
120 horas de contato com a superfície do polipropileno o número de células víaveis

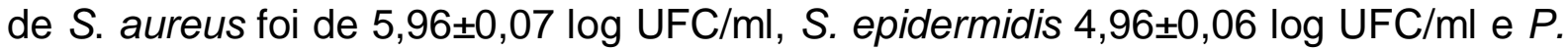
aeruginosa $6,63 \pm 0,05 \mathrm{log} U \mathrm{FC} / \mathrm{ml}$. O número de células viáveis de $S$. aureus, $S$. epidermidis e $P$. aeruginosa sobre as superfícies de poliuretano e polipropileno foram significantemente diferentes $(p<0,05)$. $O$ biofilme foi observado sobre ambos fios (poliuretano e polipropileno) como demonstrado por meio de microscopia eletrônica de varredura.

Palavras-Chave: Fios de lifting. Poliuretano. Polipropileno. Biofilme. Aderência bacteriana. 


\begin{abstract}
LEITE, B.A. Bacterial adherence and biofilm formation on facial lifting threads. 2008. 121f. Dissertação (Mestrado em Bioengenharia). Programa de Pós-Graduação Interunidades em Bioengenharia - EESC/ FMRP/ IQSC da Universidade de São Paulo, São Carlos, 2008.
\end{abstract}

Flabbiness and expression wrinkles can be helped by undergoing a face lifting or by implanting subcutaneous tissues of polyurethane or polypropylene threads. Under certain conditions microorganisms can attach themselves to the threads and interact with these surfaces initiating cellular growth. The goal of the present study was to evaluate bacterial attachment to polyurethane and polypropylene threads by means of scanning electron microscopy and microbiological method. The threads were sectioned into segments of $1.0 \mathrm{~cm}$ in length and inserted, one by one, into separated Falcon tubes $(50 \mathrm{~mL})$ containing Mueller Hinton broth $(15 \mathrm{~mL})$, with $200 \mu \mathrm{l}$ of the bacterial suspension $\left(10^{8} \mathrm{CFU} / \mathrm{mL}\right)$ prepared, and incubated for 1 hour and 30 minutes, at 4, 24, 48, 72 and 120 hour periods. After each incubation period, the coupons were rinsed three times and, inserted, one by one, into $5.0 \mathrm{~mL}$ of sterile physiological saline solution, sonicated at $40 \mathrm{kHz}$ for 8 minutes and vortexed for 10 seconds. This solution was diluted three-fold (1/10 to $1 / 1000)$, from dilution the $1 / 1000$ dilution an aliquot of $0.1 \mathrm{~mL}$ was plated onto Tryptic Soy agar (TSA). The plates were incubated at $37^{\circ} \mathrm{C}$ from 18 to $24 \mathrm{~h}$. After the incubation periods, the viable bacteria were counted and the results noted in terms of colony forming units $(\mathrm{CFU} / \mathrm{ml})$. The coupons destined for scanning electron microscopy observations were fixed in glutaraldehyde, dehydrated in alcohol series, dried in vacuum centryfuge and metalized with gold. A quantitative evaluation was recorded of the growth of $S$. aureus on the surface of polyurethane, after $1 \mathrm{~h}$ and 30 minutes of contact, the results shown 4.0 $\pm 0.0 \mathrm{CFU} / \mathrm{ml}, S$. epidermidis $4.07 \pm 0.1 \mathrm{CFU} / \mathrm{ml}$ and $P$. aeruginosa $5.08 \pm 0.14 \mathrm{CFU} / \mathrm{ml}$. After $4-120 \mathrm{~h}$ the number of viable cells of $S$. aureus on polyurethane surfaces were $5.49 \pm 0,04 \mathrm{CFU} / \mathrm{ml}, S$. epidermidis $4.99 \pm 0.07 \mathrm{CFU} / \mathrm{ml}$ and $P$. aeruginosa $6.52 \pm 0.03 \mathrm{CFU} / \mathrm{ml}$. A quantitative evaluation was recorded of the growth of $S$. aureus on the surface of polypropylene after $1 \mathrm{~h}$ and 30 minutes of contact, the results shown $4.24 \pm 0.20 \mathrm{CFU} / \mathrm{ml}$, with $S$. epidermidis $4.14 \pm 0.1 \mathrm{CFU} / \mathrm{ml}$ and $P$. aeruginosa $5.77 \pm 0.05 \mathrm{CFU} / \mathrm{ml}$. After $4-120 \mathrm{~h}$ the number of viable cells of $S$. aureus on polypropylene surfaces were $5.96 \pm 0.07 \mathrm{CFU} / \mathrm{ml}$, S. epidermidis $4.96 \pm 0.07$ $\mathrm{CFU} / \mathrm{ml}$ and $P$. aeruginosa $6.63 \pm 0.05 \mathrm{CFU} / \mathrm{ml}$. The number of viable cells of $S$. aureus, $S$. epidermidis, $P$. aeruginosa on polyurethane and polypropylene surfaces were significantly different $(p<0.05)$. A biofilm was observed on both threads (polyurethane and polypropylene) as demonstrated by scanning electron microscopy.

KeyWords: Threads of lifitng. Polyurethane. Polypropylene. Biofilm. Bacterial adherence. 


\section{LISTA DE ILUSTRAÇÕES}

Página

Figura 1: Fio de poliuretano (A - B)

Figura 2: Estrutura química dos meros do poliuretano

Figura 3: Fio de polipropileno $(A-C)$

Figura 4: Estrutura química dos meros do polipropileno

Figura 5: Microscópio eletrônico de varredura (JEOL-JSM, modelo T330A)

Figura 6: Banho ultrasônico

Figura 7: Unidades formadoras de colônia (UFC/ml)

Figura 8: Representação esquemática do método de diluição seriada

Figura 9: Representação esquemática do método de plaqueamento em superfície

Figura 10: Número de células viáveis durante a formação de biofilme 70 por S. aureus nos períodos de 1,5 - 120 horas de incubação em caldo Mueller-Hinton

Figura 11: Número de células viáveis durante a formação de biofilme por S. epidermidis no período de 1,5 - 120 horas de incubação em caldo Mueller-Hinton

Figura 12: Número de células viáveis durante a formação de biofilme 72 por $P$. aeruginosa no período de 1,5 - 120 horas de incubação em caldo Mueller-Hinton 
Figura 13: Eletromicrografia de varredura (50x) do fio de poliuretano (controle negativo) (Microscópio eletrônico de varredura, JEOL-JSM, modelo T330A).

Figura 14: Eletromicrografia de varredura da aderência e formação de biofilme de $S$. aureus sobre a superfície do poliuretano em: (A) 1,5 horas de incubação (7500x), (B) 4 horas de incubação (1500x), (C) 24 horas de incubação (3500x), (D) 48 horas de incubação (2000x), (E) 72 horas de incubação (3500x) e (F) 120 horas de incubação (3500x) (Microscópio eletrônico de varredura, JEOL-JSM, modelo T330A)

Figura 15: Eletromicrografia de varredura da aderência e formação 76 de biofilme de $S$. epidermidis sobre a superfície do poliuretano em: (A) 1,5 horas de incubação (5000x), (B) 4 horas de incubação (5000x), (C) 24 horas de incubação (5000x), (D) 48 horas de incubação (3500x), (E) 72 horas de incubação (5000x) e (F) 120 horas de incubação (7500x) (Microscópio eletrônico de varredura, JEOL-JSM, modelo T330A)

Figura 16: Eletromicrografia de varredura da aderência e formação 78 de biofilme de $P$. aeruginosa sobre a superfície do poliuretano em: (A) 1,5 horas de incubação (2000x), (B) 4 horas de incubação (2000x), (C) 24 horas de incubação (1000x), (D) 48 horas de incubação (1000x), (E) 72 horas de incubação (50x) e (F) 120 horas de incubação (1500x) (Microscópio eletrônico de varredura, JEOLJSM, modelo T330A)

Figura 17: Eletromicrografia de varredura (50x) do fio de 81 polipropileno (controle negativo) (Microscópio eletrônico de varredura, JEOL-JSM, modelo T330A) 
Figura 18: Eletromicrografia de varredura da aderência e formação

de biofilme de $S$. aureus sobre a superfície do polipropileno em: (A) 1,5 horas de incubação (3500x), (B) 4 horas de incubação (2000x), (C) 24 horas de incubação (2000x), (D) 48 horas de incubação (1500x), (E) 72 horas de incubação (2000x) e (F) 120 horas de incubação (2000x) (Microscópio eletrônico de varredura, JEOL-JSM, modelo T330A)

Figura 19: Eletromicrografia de varredura da aderência e formação de biofilme de $S$. epidermidis sobre a superfície do polipropileno em: (A) 1,5 horas de incubação (7500x), (B) 4 horas de incubação (5000x), (C) 24 horas de incubação (5000x), (D) 48 horas de incubação (5000x), (E) 72 horas de incubação (5000x) e (F) 120 horas de incubação (5000x) (Microscópio eletrônico de varredura, JEOL-JSM, modelo T330A)

Figura 20: Eletromicrografia de varredura da aderência e formação 86 de biofilme de $P$. aeruginosa sobre a superfície do polipropileno em: (A) 1,5 horas de incubação (2000x), (B) 4 horas de incubação (2000x), (C) 24 horas de incubação (3500x), (D) 48 horas de incubação (2000x), (E) 72 horas de incubação (2000x) e (F) 120 horas de incubação (500x) (Microscópio eletrônico de varredura, JEOL-JSM, modelo T330A)

Figura 21: Eletromicrografia de varredura da topografia da superfície 89 do poliuretano: (A) 50x e (B) 2000x (Microscópio eletrônico de varredura, JEOL-JSM, modelo T330A)

Figura 22: Eletromicrografia de varredura da topografia da superfície do polipropileno: (A) 1500x e (B) 50x (Microscópio eletrônico de varredura, JEOL-JSM, modelo T330A) 


\section{LISTA DE TABELAS}

Página

Tabela 1: Distribuição células viáveis de $S$. aureus recuperadas após 64 contato com a superfície do poliuretano nos tempos de 1,5-120 horas

Tabela 2: Distribuição células viáveis de $S$. aureus recuperadas após 65 contato com a superfície do polipropileno nos tempos de 1,5-120 horas

Tabela 3: Distribuição células viáveis de $S$. epidermidis recuperadas 66 após contato com a superfície do poliuretano nos tempos de 1,5-120 horas

Tabela 4: Distribuição células viáveis de S. epidermidis recuperadas 66 após contato com a superfície do polipropileno nos tempos de 1,5120 horas

Tabela 5: Distribuição células viáveis de $P$. aeruginosa recuperadas 67 após contato com a superfície do poliuretano nos tempos de 1,5-120 horas

Tabela 6: Distribuição células viáveis de $P$. aeruginosa recuperadas após contato com a superfície do polipropileno nos tempos de 1,5120 horas

Tabela 7: Distribuição da quantificação de células viáveis de $S$. aureus, $S$. epidermidis e $P$. aeruginosa recuperadas da superfície de contato de poliuretano e polipropileno

Tabela 8: Observação de biofilme usando MEV sobre a superfície do poliuretano 
Tabela 9: Observação de biofilme usando MEV sobre a superfície do polipropileno

Tabela 10: Distribuição de células viáveis de $S$. aureus recuperadas após contato com superfície do poliuretano e polipropileno após 1 hora e 30 minutos.

Tabela 11: Distribuição de células viáveis de $S$. aureus recuperadas 113 após contato com a superfície do poliuretano e polipropileno após 4 horas.

Tabela 12: Distribuição de células viáveis de $S$. aureus recuperadas 114 após contato com a superfície do poliuretano e polipropileno após 24 horas.

Tabela 13: Distribuição de células viáveis de $S$. aureus recuperadas 114 após contato com a superfície do poliuretano e polipropileno após 48 horas.

Tabela 14: Distribuição de células viáveis de $S$. aureus recuperadas 115 após contato com a superfície do poliuretano e polipropileno após 72 horas.

Tabela 15: Distribuição de células viáveis de $S$. aureus recuperadas 115 após contato com a superfície do poliuretano e polipropileno após 120 horas.

Tabela 16: Distribuição de células viáveis de $S$. epidermidis 116 recuperadas após contato com a superfície do poliuretano e polipropileno após 1 hora e 30 minutos. 
Tabela 17: Distribuição de células viáveis de $S$. epidermidis recuperadas após contato com a superfície do poliuretano e polipropileno após 4 horas.

Tabela 18: Distribuição de células viáveis de $S$. epidermidis recuperadas após contato com a superfície do poliuretano e polipropileno após 24 horas.

Tabela 19: Distribuição de células viáveis de $S$. epidermidis recuperadas após contato com a superfície do poliuretano e polipropileno após 48 horas.

Tabela 20: Distribuição de células viáveis de $S$. epidermidis 118 recuperadas após contato com a superfície do poliuretano e polipropileno após 72 horas.

Tabela 21: Distribuição de células viáveis de $S$. epidermidis 118 recuperadas após contato com a superfície do poliuretano e polipropileno após 120 horas.

Tabela 22: Distribuição de células viáveis de $P$. aeruginosa 119 recuperadas após contato com a superfície do poliuretano e polipropileno após 1 hora e 30 minutos.

Tabela 23: Distribuição de células viáveis de $P$. aeruginosa 119 recuperadas após contato com a superfície do poliuretano e polipropileno após 4 horas.

Tabela 24: Distribuição de células viáveis de $P$. aeruginosa recuperadas após contato com a superfície do poliuretano e polipropileno após 24 horas. 
Tabela 25: Distribuição de células viáveis de $P$. aeruginosa recuperadas após contato com a superfície do poliuretano e polipropileno após 48 horas.

Tabela 26: Distribuição de células viáveis de $P$. aeruginosa 121 recuperadas após contato com a superfície do poliuretano e polipropileno após 72 horas.

Tabela 27: Distribuição de células viáveis de $P$. aeruginosa 121 recuperadas após contato com a superfície do poliuretano e polipropileno após 120 horas. 


\section{Sumário}

1 Introdução

Página

20

2 Revisão da Literatura 23

$\begin{array}{ll}2.1 \text { Biomateriais } & 24\end{array}$

2.2 Aplicações do polipropileno 25

2.3 Aplicações do poliuretano natural $\quad 27$

2.4 Fios de rejuvenescimento facial 33

2.5 Aderência bacteriana com formação de biofilme 34

2.6 Etapas de desenvolvimento do biofilme 36

2.7 Aderência bacteriana/biofilme sobre superfícies de polímeros 38

3 Proposição 48

$\begin{array}{ll}3.1 \text { Geral } & 49\end{array}$

$\begin{array}{ll}3.2 \text { Específica } & 49\end{array}$

4 Material e Métodos $\quad 50$

$\begin{array}{ll}\text { 4.1 Material } & 51\end{array}$

4.1.1 Seleção dos microrganismos

4.1.2 Biomateriais 51

4.1.2.1 Fio de poliuretano $\quad 51$

4.1.2.1.1 Corpos-de-prova de poliuretano 52

4.1.2.2 Fio de polipropileno 53

4.1.2.2.2 Corpos-de-prova de polipropileno 53

4.1.3 Distribuição de corpos-de-prova 54

4.1.4 Meios de cultura e reagentes $\quad 54$

4.1.5 Reagentes utilizados para MEV 54

4.2 Métodos $\quad 55$

4.2.1 Preparação das suspensões bacterianas $\quad 55$

4.2.2 Formação in vitro de biofilme 55

4.2.3 Preparação dos corpos-de-prova para MEV 56

4.2.4 Avaliação quantitativa de células bacterianas viáveis 57

4.2.4.1 Diluições seriadas $\quad 59$

4.2.4.2 Plaqueamento em superfície 60

4.2.5 Análises estatísticas 61 
5 Resultados 63

5.1 Células viáveis $\quad 64$

5.1.1 S. aureus em contato com poliuretano e polipropileno 64

5.1.2 S. epidermidis em contato com poliuretano e polipropileno 65

5.1.3 P. aeruginosa em contato com poliuretano e polipropileno 67

5.1.4 Células viáveis de S. aureus, S. epidermidis e P. aeruginosa 68

5.2 Células viáveis apresentada graficamente $\quad 70$

5.2.1 Células viáveis de $S$. aureus após contato com polímeros 70

5.2.2 Células viáveis de $S$. epidermidis após contato com polímeros 71

5.2.3 Células viáveis de $P$. aeruginosa após contato com polímeros 72

5.3 Microscopia eletrônica de varredura (MEV) 72

5.3.1 Superfície do poliuretano 73

5.3.1.1 Superfície do poliuretano em contato com S. aureus $\quad 74$

5.3.1.2 Superfície do poliuretano em contato com S. epidermidis $\quad 76$

5.3.1.3 Superfície do poliuretano em contato com $P$. aeruginosa $\quad 78$

5.3.1.4 Superfície do poliuretano em contato com as bactérias $\quad 79$

$\begin{array}{ll}\text { 5.3.2 Superfície do polipropileno } & 81\end{array}$

5.3.2.1 Superfície do polipropileno em contato com S. aureus 82

5.3.2.2 Superfície do polipropileno em contato com S. epidermidis $\quad 84$

5.3.2.3 Superfície do polipropileno em contato com $P$. aeruginosa $\quad 86$

5.3.2.4 Superfície do polipropileno em contato com as bactérias $\quad 87$

5.3.3 Observação topográfica dos polímeros $\quad 89$

5.3.3.1 Superfície do poliuretano $\quad 89$

5.3.3.2 Superfície do polipropileno $\quad 89$

6 Discussão 95

7 Conclusão 102

$\begin{array}{ll}\text { Referências bibliográficas } & 104\end{array}$

$\begin{array}{ll}\text { Anexos } & 113\end{array}$

A - Preparação de reagentes para MEV 114

B - Soluções de etanol $\quad 115$

C - Preparação de tampão PBS e solução salina 116

D - Unidades formadoras de colônia de S. aureus, S. epidermidis e P. aeruginosa 117 
Na década de 1960, na França, Caux implantou fios de ouro no tecido celular subcutâneo (camada de gordura) da face de pacientes com flacidez da derme conseguindo melhorar a flacidez e as rugas, levando a um rejuvenescimento facial (RONDÓ et al., 1996).

Em 1999 Sulamanidze, na Geórgia, antiga União Soviética, desenvolveu os fios que no Brasil ficaram conhecidos como "APTOS" - Fios Russos. Confeccionados com polipropileno e, com "garras" nos dois lados e nos dois sentidos são utilizados da mesma maneira que os fios de ouro, porém com melhores resultados (SULAMANIDZE, 2001).

Em 2003, foi desenvolvido no Brasil o "Fio Lifting Biológico", confeccionado de poliuretano de origem vegetal (DONTOS, 2006).

O lifting facial consiste na inserção de fios no tecido subcutâneo da face, com o objetivo de estimular a produção de colágeno, minimizando marcas de expressão, flacidez da face e o envelhecimento. No processo natural de envelhecimento ocorre uma degeneração do colágeno e da elastina da derme, ocasionando uma diminuição da tonicidade e da elasticidade da pele tornando-a flácida (MÉLEGA et al., 1992).

Apesar do lifting facial, ser considerado um procedimento simples e rápido, é um procedimento invasivo e, bactérias presentes na pele como Staphylococcus aureus, Staphylococcus epidermidis e Pseudomonas aeruginosa, podem contaminar o local de inserção e colonizar o fio promovendo uma infecção.

Bactérias colonizam uma variedade de biomateriais e, o resultado dessas colonizações está diretamente relacionado com causas de infecções (GOLDMANN; PIER, 1993; KHARDORI; YASSIEN, 1995; MITTELMAN, 1996; STONE et aL., 1999). As bactérias aderidas e envoltas por polissacarídeo extracelular sobre uma 
superfície tornam-se resistentes à ação de antibióticos, ou seja, apresentam uma resistência elevada quando comparadas com células bacterianas em seu estado planctônico, ou seja, células livres (KUMON et al., 1994; STONE et aL., 1999).

A infecção sobre a superfície do implante é uma infecção agressiva e irredutível e, freqüentemente uma infecção pós-cirúrgica. A maioria das infecções sobre a superfície do implante é iniciada pela aderência de microrganismos oportunistas, por colonização e formação de biofilme sobre a superfície do implante (ARCIOLA et al., 2005; PATEL et al., 2007).

As bactérias aderem e interagem com as superfícies de implantes e iniciam crescimento celular com formação de biofilme (COSTERTON et al., 1985; ZOTOLLA; SASAHARA, 1994).

A formação de biofilme sobre superfícies de implantes, normalmente é a causa primaria de falência do implante (ARCIOLA et al., 2005). Dificilmente consegue-se erradicar a infecção sobre a superfície do implante, porque a bactéria que causa esta infecção esta presente em uma estrutura de biofilme e, muitas vezes requer-se a substituição do implante.

A análise da formação de biofilme, sobre a superfície do biomaterial pode ser realizada por métodos qualitativos como, microscopia eletrônica de varredura, mostrando células aderidas e muitas vezes observa-se a presença de uma massa amorfa caracterizando o polissacarídeo extracelular (COSTERTON et al., 1999; DONLAN, 2001). A microscopia eletrônica de varredura é utilizada para examinar e caracterizar o biofilme sobre dispositivos médicos (RAAD et al., 1993; STICKLER et al., 1998; DONLAN; COSTERTON, 2002). 


\section{1 - Biomateriais}

Os metais (titânio), cerâmica (alumina) e polímeros (poliuretanos, silicones, polipropileno) são usados na confecção de dispositivos médicos (CHEVALLAY; HERBAGE, 2000).

Algumas propriedades são requeridas para o uso do biomaterial, como composição química, estrutura atômica, capacidade de oxidação e corrosão, densidade, expansão térmica, bioadesão, ou seja, a interação entre o osso/tecido e a superfície do implante, e biocompatibilidade porque o material não deve interagir com o sistema de defesa do hospedeiro, não apresentar toxicidade ou reações inflamatórias, não causar hemólise, não liberar radicais nocivos e não ser carcinogênico (ASHBY; JONES, 1996; PADILHA, 1997).

As pesquisas sobre biomateriais vêm aumentando rapidamente. As características topográficas dos biomateriais podem ser conhecidas por meio de microscopia eletrônica de varredura. Dentre os materiais utilizados na produção dos biomateriais os polímeros oferecem ajustes específicos às exigências fisiológicas, anatômicas e cirúrgicas facilitando as opções terapêuticas na cirurgia da cabeça e da garganta (RICKERT et al., 2006).

A pesquisa sobre polímeros tem se intensificado nas últimas décadas, é grande a contribuição na área de implantes cardiovasculares, odontológicos, ópticos, neurocirúrgicos e reconstrutivos. No campo dos polímeros houve um grande avanço nos últimos anos, como o polimetilmetacrilato, cloreto de polivinila (PVC) e polipropileno, todos com vasta aplicação nas áreas médica, odontológica e biológica. Além das vantagens e desvantagens, todos apresentam um campo de aplicação determinado e restrito (STURION et al., 1999).

Outros polímeros, como o poliuretano - derivado do óleo de Ricinus 
communis, foram desenvolvidos para aplicação médica (VILARINHO et al., 1996; IGNÁCIO et al., 2002; LEONEL et al., 2004).

O termo polímero vem do grego e significa muitas partes, poli= muitos e mero $=$ partes, ou seja, o polímero é uma molécula grande com muitas unidades de repetição. Os polímeros podem ser sintéticos ou naturais. As borrachas vulcanizadas e os plásticos são exemplos de polímeros sintéticos, enquanto o couro, a seda, o algodão, a lã, são exemplos de polímeros naturais. A maioria dos polímeros foi descoberta no período entre 1930 e 1950 (ASHBY et al., 1996).

\section{2 - Aplicações do polipropileno}

Goldenberg et al. (2001) investigaram os efeitos da tela de polipropileno sobre o testículo, epidídimo e ducto deferente de cães. Foram utilizados 10 cães, machos e adultos. Era então fixada tela de polipropileno, de dimensões $2,5 \times 3,5 \mathrm{~cm}^{2}$ na região inguinal esquerda do cão em contato direto com o funículo espermático. $O$ lado direito, sem colocação de tela, serviu de controle. O procedimento tinha duração de 15 minutos. Após observação pós-operatória de 30 dias, os animais eram novamente anestesiados e re-operados sendo o testículo e ducto deferente retirados e enviados para análise histológica. No lado esquerdo (presença da tela de polipropileno) as secções histológicas de testículo revelaram focalmente, diminuição da espermatogênese e processo degenerativo em $20 \%$ dos animais. No epidídimo, observou-se inflamação crônica e dilatação dos túbulos seminíferos em $70 \%$. No ducto deferente foi observado processo inflamatório crônico em $60 \%$ dos cães. Concluíram que a tela de polipropileno em contato com o funículo espermático de cães provoca alterações histológicas com discreta redução da espermatogênese.

Melo et al. (2003), observaram os efeitos produzidos pela prótese de 
polipropileno no espaço pré-peritoneal. Utilizaram 10 cães fêmeas e adultos sem raça definida, os quais foram submetidos a inguinotomia bilateral, colocaram uma prótese de polipropileno plana $(3,5 \times 4,0 \mathrm{~cm})$ em um dos lados, e, o outro lado serviu como controle. Após 30 dias os animais foram a uma videolaparoscopia e foi realizada a avaliação macroscópica por via intraperitoneal, além do registro das alterações histológicas das duas regiões inguinais. Nenhum animal apresentou aderência no lado B (sem prótese). As alterações microscópicas no lado A (com prótese) caracterizaram-se pela proliferação de tecido conjuntivo fibroso denso, além da escassa presença de células gigantes multinucleadas, comprovando uma reação inflamatória de leve intensidade. Concluíram que a prótese de polipropileno induz a formação de aderências em $30 \%$ dos animais, quando colocada no espaço préperitoneal em cães.

Li et al. (2004) com o objetivo de identificarem materiais alternativos de sutura, que fornecessem um desempenho superior ao fio de sutura de poliéster comumente utilizado na estabilização do ombro. In vitro testaram três fios de suturas feitas do polipropileno e, compararam com o fio de sutura de poliéster. Avaliaram a facilidade de manipulação e o desempenho superior do nó. Os fios de suturas de polipropileno e poliéster deram o desempenho superior do nó, mas somente o fio de polipropileno apresentou facilidade na manipulação. Concluíram que o fio de sutura de poliéster pode ser substituído pelo fio de sutura monofilamentar de polipropileno.

Gil et al. (2005), estudaram os efeitos de múltiplas esterilizações em formaldeído em baixa temperatura, sobre a estrutura molecular (físico-químico) e desenvolvimento de microrganismos, na tela de polipropileno utilizada na correção cirúrgica das diferentes hérnias da parede abdominal. Foi estudada a tela de polipropileno plana padrão, de $15 \mathrm{~cm} \times 15 \mathrm{~cm}$, cortada em fragmentos iguais de $2 \times 1 \mathrm{~cm}$, 
após múltiplas esterilizações. Foram denominadas amostras A (controle), A1 (uma esterilização) e A3 (três esterilizações); e B (controle), B1 (uma esterilização), B2 (duas esterilizações), B3 (três esterilizações), B4 (quatro esterilizações) e B5 (cinco esterilizações). As amostras $A$ foram submetidas à análise por espectroscopia no infravermelho (FTIR) e microscopia eletrônica por varredura (MEV) e as amostras B foram semeadas em meios de Brain Heart Infusion (BHI), Ágar Sabouraud Dextrose e Ágar Chocolate. A análise comparativa das amostras A, A1 e A3 revelou evidências experimentais idênticas, do ponto de vista da composição e mesmo padrão de porosidade. Nas amostras B1-B5 não houve desenvolvimento de microrganismos nos fragmentos submetidos até cinco esterilizações. Concluíram que a tela de polipropileno não sofreu alterações na sua estrutura molecular, podendo ser submetida até cinco esterilizações, sem que ocorra o desenvolvimento de microrganismos nas amostras.

Garcia-Urena et al. (2007) estudaram a utilização da prótese de polipropileno em defeitos abdominais. Realizaram um defeito muscular em ambos os lados da parede abdominal de 15 coelhos da raça Nova Zelândia. Os defeitos foram preenchidos com a prótese de polipropileno $(5,0 \times 3,5 \mathrm{~cm})$. Cinco animais foram sacrificados após 30 dias de pós-operatório, cinco após 60 dias e cinco após 90 dias. Houve três casos de infecção pós-operatória com a presença de leucócitos. Todas as próteses de polipropileno foram integradas no tecido do coelho.

\section{3 - Aplicações do poliuretano natural}

Vilarinho et al. (1996) estudaram o comportamento dos tecidos da câmara anterior do olho do camundongo, frente a implantes do poliuretano natural acrescida ou não de carbonato de cálcio. Avaliaram a biocompatibilidade do poliuretano, a 
possível reação inflamatória e a indução de ossificação pela presença ou não de carbonato de cálcio através de estudo histológico. Os resultados mostraram que o poliuretano é bem tolerado pelos tecidos da câmara anterior do olho do camundongo, havendo uma reação inflamatória inicial que diminui com o passar do tempo. O grupo de camundongos que receberam implantes acrescidos de carbonato de cálcio mostrou-se semelhantes aos do grupo de camundongos quem receberam implantes sem carbonato de cálcio. O poliuretano derivado do óleo de Ricinus communis mostrou compatibilidade com os tecidos da câmara anterior do olho do camundongo apresentando aspectos favoráveis de processabilidade, flexibilidade de formulação, versatibilidade da temperatura e controle do pico exotérmico.

Fuentefria et al. (1998) avaliaram histologicamente a reação tecidual ao implante do poliuretano, implantado na tíbia de ratos. Utilizou-se 21 ratos para análises. Foram preparadas cavidades ósseas nas tíbias direita e esquerda dos animais. A cavidade do lado teste foi obturada com o poliuretano. No lado controle não se implantou material algum, permanecendo o coágulo sangüíneo. Realizaram o sacrifício dos animais após 7,14 e 21 dias da cirurgia, e a seguir realizaram a análise histológica, por meio de microscopia óptica. Os resultados obtidos, como a ausência de abscessos nas áreas que receberam o implante do poliuretano, permitiram os autores levantarem a hipótese de biocompatibilidade. As observações quanto ao infiltrado inflamatório, no lado teste dos animais, mostrou uma reação discreta em todas as amostras. A presença de células gigantes multinucleadas foi rara. Concluíram que o uso do poliuretano natural, como material de implante, não apresentou diferença estatisticamente significante, em relação aos processos de cicatrização observados nas amostras controle.

Rezende et al. (2001) estudaram a eficácia da prótese de poliuretano 
derivado do óleo de Ricinus communis como substituto parcial do tendão calcâneo comum. Foram utilizadas 30 coelhas da raça Nova Zelândia, entre dois e três meses de idade. Após a tenectomia do tendão a prótese de poliuretano $(0,5 \times 0,5 \mathrm{~cm})$ foi fixada, empregando-se o fio de polipropileno monofilamentar para a sutura local. Após o retorno anestésico, todos os animais apoiaram os membros operados imediatamente. Não observaram sinais clínicos de infecção. Ocorreu aumento de volume local devido ao edema, que gradualmente desapareceu. Clinicamente concluíram que a prótese de poliuretano natural não induziu reação que comprometesse a cicatrização tendínea, podendo ser indicado como substituto temporário de tendão.

Ignácio et al. (2002) estudaram a biocompatibilidade do poliuretano derivado do óleo de Ricinus communis nas formas compacta (ausência de poros) e porosa no preenchimento de falha óssea. Realizaram defeitos ósseos em fêmures e tíbias de 18 cães e preencheram com o poliuretano. Os animais foram sacrificados aos três, seis e 12 meses de cirurgia. Observaram macroscopicamente a aderência do poliuretano no interior dos defeitos ósseos, especialmente nos porosos. Por meio da microscopia eletrônica de varredura observaram a formação de uma estrutura com morfologia semelhante ao tecido conjuntivo fibroso na interface osso-poliuretano. No tempo de evolução de 12 meses essa estrutura penetrou superficialmente no interior dos poros existentes. Histologicamente não verificaram a reação de corpo estranho ou de células fagocitárias e não observaram sinais de irregularidades na superfície do poliuretano em contato com o tecido ósseo, indicativos de reabsorção do material. Concluíram que o poliuretano de origem natural foi biocompatível.

Souza et al. (2003) avaliaram a utilização do poliuretano natural em formas de blocos pré-fabricados para utilização nas reconstruções de grandes falhas ósseas 
decorrentes de tumores benignos agressivos e tumores malignos. Avaliaram 20 pacientes. As falhas ósseas foram reconstruídas com blocos pré-fabricados do poliuretano, tendo sido adaptados e fixados. Sete pacientes $(35 \%)$ obtiveram resultados excelentes, 4 pacientes $(20 \%)$ bons, 4 pacientes $(20 \%)$ regulares e 5 pacientes (25\%) de falhas. O poliuretano apresentou como vantagens: disponibilidade; baixo custo; ausência de riscos de transmissão de doenças e apresentou biocompatibilidade. O poliuretano natural foi considerado uma alternativa viável para reconstrução de falhas ósseas pós-ressecção de tumores benignos agressivos e malignos.

Leonel et al. (2004) estudaram a ação do poliuretano natural, durante a neoformação óssea. Para isto um grupo de 45 ratos foi utilizado. Realizaram um defeito ósseo na região arco zigomático de todos os animais, segmento ósseo de $2 \mathrm{~mm}$ foram seccionados, sendo que todos estes defeitos foram preenchidos com o poliuretano em forma de blocos pré-polimerizados, que permitiam a escultura do mesmo a semelhança do fragmento ósseo removido. Após 120 dias os animais foram sacrificados, e realizaram análise histológica. Concluíram que o poliuretano auxiliou no processo regenerativo do defeito ósseo criado experimentalmente. A utilização do poliuretano durante a neoformação óssea, comprova a propriedade de osteocondução do material, ou seja, a capacidade de conduzir ou direcionar a neoformação óssea sobre e entre a estrutura do material de preenchimento. $O$ polímero apresentou como propriedades a biocompatibilidade, não foram tóxicos ou carcinogênicos, apresentou resistência mecânica, elasticidade, estabilidade química e biológica e, não liberaram vapores e radicais tóxicos quando implantados.

Dontos (2006) na primeira fase do estudo comparou a biocompatibilidade do fio de poliuretano derivado do óleo de Ricinus communis com o fio de polipropileno. 
Implantados no dorso de 15 camundongos. Avaliou histologicamente o grau da resposta inflamatória do tecido celular subcutâneo, a formação de fibroblastos e conseqüentemente a formação de colágeno. Os 15 camundongos foram divididos em 5 grupos. Os animais do grupo I foram sacrificados com 30 dias, e os dos grupos II, III, IV e V foram sacrificados após 03, 07, 15 e 30 dias, respectivamente. Por meio de análise histológica, sobre o fio de poliuretano derivado do óleo de Ricinus communis, observou: Após 3 dias - Desorganização do tecido conjuntivo com fibrilas de colágeno; 7 dias - Tecido conjuntivo em reorganização. Presença de fibrilas de colágeno e fibroblastos em atividade. Pequena quantidade de células inflamatórias (macrófagos); 15 dias - Presença de fibrilas de colágeno e grande quantidade de fibroblastos em atividade. Raras células inflamatórias sobre o fio; 30 dias - Fibras de colágeno neoformado e fibroblastos. Sobre o fio de polipropileno observou: Após 3 dias - Presença de macrófagos; 15 dias - Grande quantidade de células inflamatórias (macrófagos); 30 dias - Presença de fibrilas de colágeno. Com base na avaliação histológica, o fio de poliuretano natural obteve uma rápida formação de colágeno e ausência de inflamação, enquanto que sobre o fio de polipropileno observou uma formação de colágeno tardia e grande quantidade de células inflamatórias. O fio de poliuretano natural apresentou maior biocompatibilidade com 0 dorso de camundongo e menor nível de rejeição comparado ao fio de polipropileno. $\mathrm{Na}$ segunda fase do estudo, implantou fio de poliuretano derivado do óleo de Ricinus communis no tecido celular subcutâneo da face em pacientes que apresentavam flacidez dérmica e sinais de envelhecimento, com o objetivo de obter rejuvenescimento facial, através do reposicionamento dos tecidos e formação de colágeno. O fio de poliuretano natural foi implantado no tecido celular subcutâneo da face de 15 pacientes, sendo 02 homens e 13 mulheres, com idades variando entre 
35 e 68 anos. Observou o rejuvenescimento facial por meio de fotografias pré e, pósoperatórias. Após 7 dias pós-operatório observou uma retração das bolsas laterais da face com melhor definição da linha mandibular. Com 30 dias pós-operatório, obtiveram uma melhora da flacidez dérmica, aumento do volume da região zigomática, diminuição da flacidez cervico-mandibular, ganho de volume na região zigomática e diminuição do sulco nasogeniano. Esta segunda fase do estudo visou implantar fios de poliuretano natural no tecido subcutâneo da face, para amenizar rugas de expressão e combater a flacidez da pele, acometidos por meio do envelhecimento facial.

O envelhecimento facial é um processo dinâmico continuo durante toda a vida adulta que se inicia logo após o termino do crescimento geral do organismo aos 25 anos de idade e decorre de vários fatores complexos, intrínsecos e extrínsecos, agindo em conjunto. Os fatores intrínsecos são devidos à herança genética e os extrínsecos são resultado de hábitos individuais como exposição solar, nutrição, tabagismo, etc (MÉLEGA et al., 1992).

Após as idades de 45 anos para o homem e 35 anos para a mulher ocorre uma gradual diminuição da espessura da pele, que é maior no sexo masculino, pois a quantidade total de colágeno é maior nos homens. Alguns autores quantificaram o colágeno humano ao longo do tempo e verificaram que ocorre um decaimento de cerca de $1 \%$ a cada ano, em ambos os sexos (FRED; FEDOK, 1996).

O envelhecimento facial ocorre de forma gradual. Tornando-se mais aparente a presença de sulcos lagrimais, rugas de expressão e flacidez da pele (SULAMANIDZE et al., 2002).

$\mathrm{Na}$ tentativa de se atenuar esta alteração várias técnicas cirúrgicas foram desenvolvidas, entre elas a que pode ser denominada de dermossustentação. Esta 
técnica consiste em se implantar fios cirúrgicos de diversos materiais (colágeno, ouro, seda, politetrafluoretileno, polipropileno, poliuretano) no tecido celular subcutâneo da face logo abaixo da derme com intuito de se provocar uma tensão mecânica, reposicionando as estruturas faciais ptosadas e estimular a formação de colágeno e elastina obtendo-se assim um rejuvenescimento facial (ADAMAYAN, 1998; LEEGRAND et al., 1998; ODO; CHICHIERCHIO, 1999).

\section{4 - Fios de rejuvenescimento facial}

Desde a década de 60, Caux médico francês, implantou fios de ouro no tecido celular subcutâneo (camada de gordura logo abaixo da pele) da face, em pacientes com flacidez da pele e conseguiu bom rejuvenescimento facial. Fios de ouro foram considerados por este médico, um material seguro para implante na face, devido sua pureza, sua densidade, sua cor e maleabilidade (RONDÓ et al., 1996).

Em 1999, foram introduzidos no Brasil o fio "APTO" - fio de polipropileno, também chamados de fio Russo porque foram desenvolvidos por Dr. Marlen Sulamanidze, cirurgião de origem Russa. Estes eram preparados com derivado de petróleo, o polipropileno. O fio é biocompatível, não absorvível, não biodegradável e de forte resistência. Não provoca reações alérgicas, não é rejeitado pelo organismo e resiste a grandes tensões. Os fios de polipropileno apresentam uma dupla fileira de "garras", que correm em sentidos opostos e, em direção ao centro do fio. As garras se prendem firmemente ao tecido gorduroso da face e, ao passo que o organismo tenta expulsá-lo, o fio vai erguendo ainda mais a região tratada. A pele se acomoda naturalmente a elevação da camada de gordura, sem gerar dobras ou rugas (SULAMANIDZE et al., 2001).

Em 2003, foi desenvolvido pelo grupo de Química Analítica e Tecnologia dos 
Polímeros-USP/ São Carlos, o fio de poliuretano, derivado do óleo de Ricinus communis, para ser usado em lifting facial (DONTOS, 2006).

Corpos estranhos estão associados com um risco substancial de infecções bacterianas ou fungicas (VON EIFF et al., 2005). Estas infecções normalmente são a causa primaria de falência do implante (ARCIOLA et al., 2005).

\section{5 - Aderência bacteriana com formação de biofilme}

A matriz de polímeros extracelulares que mantém o biofilme coeso freqüentemente denominado por exopolissacarídeo (EPS), é possivelmente, responsável pela persistência das infecções relacionadas com biofilmes (COSTERTON et al., 1978).

Biofilmes são agregados de microrganismos embebidos em uma matriz polimérica e aderidos a uma superfície sólida, formando uma estrutura porosa e altamente hidratada contendo exopolissacarídeo (LAWRENCE et al., 1991).

A adesão microbiana e a formação de biofilme ocorrem em virtude da deposição de microrganismos em uma superfície de contato, onde eles se fixam e iniciam o crescimento (ZOTTOLA; SASAHARA, 1994).

As bactérias em biofilme não crescem exponencialmente. Elas existem em crescimento lento ou estacionário. Estudo de infecções, relacionadas a implantes ortopédicos em um modelo animal confirmaram o crescimento lento do Staphylococcus aureus e Escherichia coli (COSTERTON et al., 1999).

Biofilme consiste de microcolônias heterogêneas, funcionalmente organizadas onde a bactéria é protegida da ação de macrófagos, além de fornecer resistência aos antibióticos. Até mesmo, uma pessoa que apresente uma resposta imune excelente, raramente soluciona a infecção ocasionada por biofilmes sobre a 
superfície de implante apenas por apresentar um mecanismo de defesa e, sobre muitos casos, requer-se uma substituição do implante (COSTERTON et al., 1999; BELLÓN et al., 2001).

A formação de um biofilme permite que a bactéria permaneça sobre a superfície do material até que consiga se multiplicar em um ambiente favorável, com uma diminuição da resposta imune do paciente ocorre à infecção sobre o biomaterial. Isto explica o surgimento tardio da infecção. Em alguns pacientes a infecção pode surgir até mesmo após anos depois do implante (TAYLOR; DWYER, 1999; BELLÓN et al., 2001).

Os biofilmes demonstram resistência a desinfetantes, antibióticos e à radiação ultravioleta (ELASRI; MILLER, 1999). A radiação ultravioleta, não produz nenhum efeito sobre as células contidas no biofilme. O biofilme apresenta uma propriedade protetora à radiação ultravioleta (MOHAMED; MILLER 1999). O biofilme protege os microrganismos de antibióticos, estudos experimentais in vitro revelam que células bacterianas contidas em biofilmes são mais resistentes a antibióticos do que células no estado planctônico (CERI et al., 2001).

O desenvolvimento de biofilmes tem um impacto negativo em várias atividades como, estrago de equipamentos através da biocorrosão, comprometimento de dispositivos médicos, entre outros. Tais problemas são agravados, pela resistência acrescida aos antibióticos que os biofilmes demonstram, comparando com células bacterianas livres (SIMÕES et al., 2003).

Biofilmes têm uma importância clínica relevante especialmente com respeito a sua formação em cateteres urinários e válvulas cardíacas (GRISTINA, 1987; PAN et al., 2004).

Fios de sutura de nylon usados em cirurgias oftálmicas permitem a 
aderência bacteriana que, podem originar infecções severas (ACHESON; LYONS, 1991; HEAVEN; BOASE, 1993; PAN et al., 2004).

Tem-se uma grande preocupação com os implantes médicos frente à infecção, pois a bactéria presente na infecção adere-se ao polímero, por uma adesão irreversível, e levando a multiplicação celular, com formação do biofilme (COSTERTON et al., 2005).

A contaminação bacteriana durante a cirurgia e, com subseqüente adesão bacteriana sobre a superfície de biomaterial, se dá por microrganismos oportunistas, como espécies de Staphylococcus, levando a formação de biofilme (ARCIOLA et al., 2005).

\subsection{1 - Etapas de desenvolvimento do biofilme}

A formação e, desenvolvimento do biofilme ocorre em cinco estágios (STOODLEY et al., 2002; SAUER et al., 2002).

No primeiro estágio ocorre a aderência inicial das células microbianas sobre uma superfície de contato (STOODLEY et al., 2002). Quando o biomaterial é colocado dentro do corpo humano e, exposto a fluidos corporais como, sangue, urina e saliva, componentes macromoleculares recobrem a superfície do dispositivo imediatamente para formar um filme condicionante. O filme condicionante formado sobre a superfície do biomaterial permite a aderência inicial do microrganismo (GRISTINA, 1987; REID et al., 1994; CHAMBERLAIN, 1992; SCHAKENRAAD et al., 1998; CHOONG; WHITFIELD, 2000).

Bactérias planctônicas, ou seja, bactérias livres que flutuam livremente no fluido corporal, aderem-se a superfície do biomaterial, inicialmente por uma adesão reversível (MARSHALL et al., 1971; STOODLEY et al., 2002). 
No segundo estágio ocorre a produção do polissacarídeo extracelular resultando na aderência irreversível dos microrganismos a superfície de contato. O polissacarídeo extracelular é constituído por proteínas, polissacarídeo e ácidos nucléicos. Neste estágio as células microbianas aderidas a superfície do biomaterial, iniciam a multiplicação celular, e o polissacarídeo extracelular atua como uma "cola" para agrupar as células microbianas (NIVENS et al., 2001; STOODLEY et al., 2002).

O terceiro estágio é caracterizado pelo desenvolvimento da arquitetura do biofilme (caracterizando a forma de "cogumelo") (STOODLEY et al., 2002).

A estrutura básica de um biofilme é constituída de células microbianas de uma ou mais espécies. O biofilme é composto de 10-25\% por microrganismos e 7590\% por polissacarídeo extracelular (COSTERTON, 1999).

No quarto estágio ocorre a maturação da arquitetura do biofilme, ou seja, o biofilme é caracterizado pelo formato de "cogumelo" (STOODLEY et al., 2002). Os microrganismos contidos dentro do biofilme, permitem a entrada de proteínas e oxigênio (STOCK et al., 1990; GOODMAN; MARSHALL, 1995; CHOONG; WHITFIELD, 2000).

O quinto estágio é caracterizado pela dispersão de células presentes no biofilme. Neste estágio ocorre o "quorum-sensing", ou seja, a comunicação entre as células microbianas para, que parte das células contidas no biofilme sejam dispersas, ou seja, tornem-se células planctônicas e, estas células livres novamente irão encontrar uma nova superfície de aderência e formar um novo biofilme (STOODLEY et al., 2002). 


\section{7 - Aderência bacteriana e formação de biofilme sobre superfícies de polímeros}

Russell et al. (1987) compararam a aderência do Staphylococcus aureus e Staphylococcus epidermidis em cateteres intravenosos de poliuretano e de policloreto de vinila (PVC). Os cateteres foram colocados separadamente em tubos e inoculados com suspensões de Staphylococcus aureus e Staphylococcus epidemidis separadamente e incubados a $37^{\circ} \mathrm{C}$ por 4 horas. Após o período de incubação, os cateteres foram observados por meio de microscopia eletrônica de varredura. Houve aderência em ambos os cateteres, porém observaram que sobre os cateteres de policloreto de vinilia (PVC) houve uma maior aderência de ambos os microrganismos comparado aos cateteres de poliuretano. Sobre os cateteres de poliuretano houve maior aderência por S.aureus e, sobre os cateteres de policloreto de vinila (PVC) houve maior aderência por S.epidermidis. Por meio da microscopia eletrônica de varredura observaram que as superfícies dos cateteres intravenosos são imperfeitas. Os cateteres de policloreto de vinila (PVC) apresentaram maiores irregularidades de superfície. S. aureus e S. epidermidis aderiram às irregularidades de superfície dos cateteres intravenosos. Concluíram que a composição do cateter pode influenciar, a aderência da bactéria.

Akiyama et al. (1993) estudaram a aderência e formação de biofilme do Staphylococcus aureus sobre a superfície de fios de seda introduzidos na pele de ratos. Após 1, 3, 6, 12, 24, 48 e 72 horas de incubação os fios foram removidos e analisados por meio de microscopia eletrônica de varredura. Em 1 hora de incubação, observou-se uma aderência inicial, em 3 horas de incubação observouse a presença de micro-colônias, 12 horas de incubação S. aureus estava envolto por polissacarídeo extracelular. S. aureus formou biofilme sobre fios de seda, 
confirmados por meio de MEV.

Nagaoka; Kawakami (1995) estudaram em superfícies de polímeros, policloreto de vinila (PVC) e polietileno a aderência bacteriana in vitro por Staphylococcus aureus e Escherichia coli. Os polímeros (PVC e polietileno) foram depositados em suspensões do $S$. aureus e E. coli, individualmente e incubados a $3^{3} \mathrm{C}$, por 24 horas. As estruturas foram analisadas por meio de microscopia eletrônica de varredura (MEV). Observaram a aderência bacteriana e a formação de biofilme em ambos os polímeros (policloreto de vinilia e polietileno).

Joyanes et al. (2000), estudaram in vitro a aderência do Enterococcus faecalis e Enterococcus faecium sobre a superfície de cateteres de látex siliconizado (Foley) e cateteres de silicone (USA). A suspensão bacteriana $\left(2,5 \times 10^{5} \mathrm{UFC} / \mathrm{ml}\right)$ foi inoculada separadamente em 10,0ml de Tryptic Soy broth (TSB), contendo separadamente segmentos de $0,5 \mathrm{~cm}$ de cada tipo de cateter, e foram incubados por 1-120 horas a $37^{\circ} \mathrm{C}$. Após cada período de incubação, os corpos-de-prova eram lavados com salina tamponada com fosfato (PBS) e, a seguir os corpos-de-prova em 1,0ml de tampão PBS foram sonicados por 1 minuto e submetidos ao vortex por 15 segundos. Após este procedimento, realizaram diluições seriadas e $10 \mu \mathrm{l}$ foram semeados em placas contendo Tryptic Soy agar. As placas foram incubadas a $37^{\circ} \mathrm{C}$ por 48 horas, e o número de colônias crescidas foram contadas. A aderência bacteriana ocorreu rapidamente, com um pico máximo após 24 horas de incubação. A aderência de E. faecium foi menor sobre ambos os biomateriais, quando comparada a aderência por E. faecalis.

PINNA et al. (2000) estudaram in vitro a aderência do Staphylococcus epidermidis em lentes intra-oculares. A aderência foi testada em 12 lentes de polimetilmetacrilato (PMMA) e, em 12 lentes de acrílico. Seis lentes intra-oculares (3 
de cada tipo) foram incubadas separadamente em diferentes tubos, contendo uma suspensão bacteriana $\left(10^{8} \mathrm{UFC} / \mathrm{ml}\right)$ de $S$. epidermidis e, incubados a $37^{\circ} \mathrm{C}$, por 3 minutos, 30 minutos e 90 minutos. Cada lente intra-ocular foi removida do tubo e lavada com salina estéril e, transferidas separadamente para tubos com caldo de Infusão Cérebro Coração. Os tubos foram sonicados por três minutos para remover bactérias aderidas as lentes intra-oculares. Realizaram duas diluições, e a seguir semearam em placas contendo Agar Manitol. Para contagem de bactérias viáveis. As placas foram incubadas a $37^{\circ} \mathrm{C}$ a noite toda, após o período de incubação as colônias foram contadas. O teste foi realizado em triplicata. Seis lentes intra-oculares (3 de cada tipo) foram incubadas separadamente em diferentes tubos, contendo uma suspensão bacteriana $\left(10^{8} \mathrm{UFC} / \mathrm{ml}\right)$ de $S$. epidermidis e, incubados a $37^{\circ} \mathrm{C}$, por 3 minutos, 30 minutos e 90 minutos. Após o período de incubação as lentes intraoculares foram preparadas para microscopia eletrônica de varredura (MEV). Observaram a aderência de $S$. epidermidis em ambas as lentes intra-oculares porem, sobre as lentes intra-oculares de acrílico observaram maior aderência do $S$. epidermidis. S. epidermidis aderiu-se às irregularidades das lentes intra-oculares e, tem causado infecções pós-cirúrgicas de cataratas. Concluíram que a aderência do S. epidermidis é influenciada pelo tipo de material da lente intra-ocular.

Bellón et al. (2001) estudaram a aderência bacteriana sobre próteses, pois a infecção sobre um material de implante pode ter várias conseqüências e, muitos pacientes necessitam até mesmo substituir a prótese. Portanto, analisaram in vitro, os efeitos do Staphylococcus aureus e Staphylococcus epidermidis sobre próteses de polipropileno e politetrafluoretileno. Fragmentos das próteses $\left(1 \mathrm{~cm}^{2}\right)$ foram inoculados separadamente com $S$. aureus e $S$. epidermidis, e, $S$. aureus com $S$. epidermidis $\left(10^{8}\right.$ UFC). O efeito da bactéria sobre a prótese foi observado por 30 
dias, por meio de microscopia eletrônica de varredura (MEV), para confirmar a presença da bactéria sobre a prótese, foi realizado Gram e prova imunohistoquímica para a identificação do $S$. aureus. Por meio da microscopia eletrônica de varredura observaram a aderência bacteriana e formação de biofilme sobre as próteses. Concluíram que $S$. aureus e $S$. epidermidis, colonizam regiões das próteses de polipropileno e politetrafluoretileno.

Yokoo et al. (2004) estudaram a aderência bacteriana e formação do biofilme por Staphylococcus aureus, sobre a superfície do polietilenotereftalado (PET). Uma suspensão de S.aureus foi inoculada em caldo Mueller-Hinton e os corpos-de-prova de polietilenotereftalado foram incubados por 30 minutos, 2, 24 e 48 horas, 15 e 30 dias. Após os períodos de incubação, os corpos-de-prova foram preparados e analisados por microscopia eletrônica de varredura (MEV). Os resultados da análise por MEV mostraram que as superfícies do PET permitiram a aderência de $S$. aureus com a formação do biofilme.

Pan et al. (2004) avaliaram a formação de biofilme in vitro em fios de suturas de nylon removidas após cirurgia de catarata. Foram removidos 10 fios de sutura de 10 pacientes, sendo 3 homens e 7 mulheres. Os fios foram removidos em tempos diferentes, variando entre 5 a 88 semanas a remoção dos fios de sutura, após a cirurgia de catarata. Imediatamente após a remoção os fios eram preparados para análise por meio de microscopia eletrônica de varredura. Não evidenciou a formação do biofilme nos fios de sutura removidos após a cirurgia de catarata.

Locatelli et al. (2004) estudaram a aderência bacteriana, in vitro, sobre lentes intra-oculares de silicone e de polimetilmetacrilato como possível fator de risco no desenvolvimento de endoftalmite pós-operatória. Realizaram análises com as cepas de Staphylococcus aureus, Staphylococcus epidermidis e Pseudomonas aeruginosa 
incluindo a determinação de curvas de crescimento, testes para verificação de produção de cápsula, avaliação da hidrofobicidade, testes de aderência a diferentes materiais, microscopia óptica, microscopia eletrônica de varredura e microscopia de força atômica. A produção de cápsula e a aderência das três diferentes cepas não mostraram qualquer relação com a quantidade de microrganismos; em relação às lentes intra-oculares de polimetilmetacrilato e de silicone, não houve diferença estatisticamente significativa na aderência de $S$. aureus e $S$. epidermidis. $P$. aeruginosa foi o microrganismo mais aderente a ambos os materiais. A microscopia eletrônica de varredura confirmou estes achados em relação à aderência, ao passo que a microscopia de força atômica evidenciou a formação de biofilme pelas cepas de S. aureus, S. epidermidis e P.aeruginosa. Constatou-se que $P$. aeruginosa apresentou maior eficiência de adesão entre as bactérias testadas. Todas as cepas produziram biofilme. As lentes intra-oculares de silicone foi o material mais hidrofóbico, quando comparado ao polimetilmetacrilato.

Buret et al. (2004) estudaram a formação do biofilme sobre superfície de implante de silicone. O implante subdérmico de silicone foi colonizado com Pseudomonas aeruginosa e, introduzido na cavidade peritoneal de coelhos adultos. Após 4, 8, 28 e 42 dias pós-cirurgia, os implantes foram removidos e observados a formação de biofilme sobre a superfície do implante de silicone. Observaram a formação do biofilme por Pseudomonas aeruginosa em todas as fases experimentais.

Aoki et al. (2005), estudaram 25 cateteres de poliuretano de hemodiálise, com um total de 16 pacientes (7 homens, 9 mulheres). Os cateteres inseridos em veia subclávia, permaneceram por 3 a 91 dias. Os cateteres foram removidos devidos o mau funcionamento, suspeita de infecção relacionada ao cateter, 
viabilidade de um acesso permanente, remoção acidental, sinais e sintomas de infecção no local da inserção do cateter e contaminação exógena. Culturas positivas de ponta foram observadas em sete cateteres, sendo identificado por cultura de sangue Staphylococcus aureus. Biofilme foi observado sobre todas as pontas de cateteres.

Storti et al. (2005) estudaram a detecção de biofilmes microbianos mistos em cateteres venosos de pacientes de Unidades de Terapia Intensiva. Os cateteres foram avaliados por métodos microbiológicos (cultura semi-quantitativa) e microscopia eletrônica de varredura a fim de detectar a adesão microbiana e correlacionar com a cultura de sangue. Avaliaram 63 pontas de cateter. Os cateteres que foram analisados eram de poliuretano. Observaram infecção com maior freqüência em cateteres com tempo de permanência maior do que sete dias. Os microrganismos isolados incluíram estafilococos coagulase-negativa, bactérias Gram-negativas, estafilococos coagulase-positiva, e leveduras. Como agentes causais de infecções foram isolados $E$. aerogenes, P.aeruginosa, A. baumannii. As análises por meio de microscopia eletrônica de varredura revelaram biofilmes sobre a superfície de todos os cateteres examinados.

Belangero et al. (2006) avaliaram por meio de microscopia eletrônica de varredura as superfícies internas e externas de cateteres de diálise peritoneal, retirados de crianças em programa de diálise peritoneal crônica. Foram avaliados 11 cateteres. Foram confeccionados fragmentos nos cateteres e avaliado as características das fibras que compõem o material e a presença e localização de microrganismos e biofilme. Os resultados mostraram desestruturação das fibras, irregularidade na sua disposição, com formação de crateras e desgaste no contorno dos furos, de todos os cateteres analisados. Observaram imagens sugestivas de 
microrganismos em diferentes locais, sendo que a ponta do cateter foi a região que continha maior freqüência e intensidade de microrganismos. Os autores concluíram que o processo de fabricação da ponta do cateter deve ser reavaliado, com fins de redução da colonização de microrganismos neste local e, a superfície do cateter não deve ser irregular, que provavelmente facilitaram a proliferação dos microrganismos.

Cangemi et al. (2006) estudaram a biodegradação do poliuretano derivado do óleo de Ricinus communis. O poliuretano com $3 \mathrm{~cm}$ de comprimento, foi esterilizada na autoclave por 20 minutos a $127^{\circ} \mathrm{C}$ e, inoculado separadamente em placas contendo suspensões de Aspergillus sp e Chryseobacterium meningosepticum. Após o período de incubação de 156 dias a temperatura ambiente, o poliuretano foi preparado para microscopia eletrônica de varredura. Os resultados sugeriram que a degradação do poliuretano natural ocorre. Essa ação de degradação pode ser atribuída à ação dos microrganismos.

Gus et al. (2006) estudaram in vitro a aderência das bactérias Staphylococcus epidermidis e Pseudomonas alcaligenes em diferentes tipos de lentes intra-oculares. Utilizaram 14 lentes intra-oculares, sendo 4 de silicone, 4 de polimetilmetacrilato (PMMA), 4 de hidrogel e 2 de acrílico. Oito lentes intra-oculares (duas de cada material) foram colocadas separadamente em tubos de ensaio contendo $4 \mathrm{ml}$ de suspensão de $P$. alcaligenes, e seis lentes intra-oculares (duas de cada material, exceto as lentes de acrílico) foram colocadas separadamente em tubos de ensaio contendo $4 \mathrm{ml}$ de suspensão de $S$. epidermidis. Após 2 horas de incubação a $37^{\circ} \mathrm{C}$, as amostras que tiveram crescimento bacteriano, foram numeradas por meio de métodos convencionais de laboratório. Todos os testes foram realizados em duplicata. A aderência do $S$. epidermidis nas lentes de polimetilmetacrilato (PMMA) foi menor comparada com as de silicone e de hidrogel. 
A aderência da $P$. alcaligenes nas lentes de hidrogel foi menor comparada com as de silicone, polimetilmetacrilato (PMMA) e acrílico. Concluíram que a aderência do $S$. epidermidis e da $P$. alcaligenes nas lentes intra-oculares é influenciada pelo tipo de material da lente.

Katsikogianni et al. (2006) realizaram estudo com Staphylococcus epidermidis na associação de infecções em implantes médicos. Analisaram a aderência do $S$. epidermidis sobre a superfície de policloreto de vinila (PVC). A aderência bacteriana foi observada por meio da microscopia eletrônica de varredura (MEV), microscopia de força atômica (MFA) e microscopia de fluorescência. Os resultados mostraram a aderência do $S$. epidermidis sobre a superfície do policloreto de vinila (PVC).

Mackintosh et al. (2006) estudaram a adesão bacteriana com formação de biofilme em superfícies de polietilenotereftalado (PET), incluindo superfícies com variações hidrofílicas, hidrofóbicas e caráter iônico. As superfícies do polietilenotereftalado (PET), presente em salina tamponada com fosfato (PBS), foram analisadas em 48 horas e, observou a aderência bacteriana com a formação de biofilme por Staphylococcus epidermidis, bactéria comum da pele. As variações das superfícies não interferiram na formação do biofilme. A superfície com caráter hidrofílico apresentou menor aderência bacteriana, comparada a superfície aniônica e catiônica.

Olson et al. (2006) avaliaram, in vitro, o papel da adesina polissacarídea do Staphylococcus epidermidis frente a biomateriais ortopédicos. A causa mais comum de infecção em dispositivos ortopédicos é iniciada por $S$. epidermidis e, a adesina polissacarídea tem um papel essencial na formação e agregação do biofilme. Os biomaterais ortopédicos testados foram de polietileno, polimetilmetacrilato, titânio, 
aço inoxidável, zircônio e cobalto. Em todos os biomateriais testados o $S$. epidermidis aderiu, porém o S.epidermidis com a adesina exibiu níveis maiores de adesão. Concluíram que a adesina polissacarídea pode servir como um fator determinante de virulência em infecções protéticas por dispositivos ortopédicos.

Bernardi et al. (2007), estudaram a produção de slime em 27 cepas de estafilococos coagulase-negativa. A produção de slime é um importante fator de virulência dos estafilococos coagulase-negativa, permitindo-lhes aderir sobre a superfície lisa de biomateriais e, por isso, é associada a processos de infecção de implantes. As 27 cepas foram investigadas por cultura, método da microplaca e microscopia eletrônica de varredura. Foi também avaliada a resistência de estafilococos coagulase-negativa a vários antimicrobianos usando a técnica do disco difusão. Todos os estafilococos coagulase-negativa foram sensíveis a vancomicina. As cepas isoladas de cateter venoso central foram identificadas por método convencional. Os 27 estafilococos coagulase-negativa foram identificados como: $S$. saprophyticus $(3,7 \%)$, S. xylosus $(7,4 \%)$, S. haemolyticus $(14,8 \%)$, S. epidermidis $(37,0 \%)$, S. warneri $(14,8 \%)$, S. lugdunensis $(7,4 \%)$, S. hominis $(7,4 \%)$, S. schleiferi $(3,7 \%)$ e S. chromogenes (3,7\%). Pode-se concluir que entre a maioria das espécies Staphylococcus coagulase-negativa houve associação entre a produção de slime, origem nasocomial das cepas e reduzida sensibilidade aos antimicrobianos, sugerindo potencial patogênico no ambiente hospitalar.

Patel et al. (2007) analisaram, in vitro, a adesão e formação do biofilme por Staphylococcus epidermidis em superfície de implante cardiovascular de poliuretano modificados com óxido de polietileno (superfície hidrofílicas) e fluorcarbono (superfície hidrofóbicas). A maioria das infecções nos implantes cardiovasculares são iniciadas por $S$. epidermidis e levam a formação do biofilme. Separadamente 
colocaram os poliuretanos modificados (superfície hidrofílica e superfície hidrofóbica) em Tryptic Soy Broth (TSB) em presença da suspensão do S. epidermidis. Observaram a formação do biofilme após, 12, 24 e 48 horas de incubação. Sobre a superfície do poliuretano hidrofílico, observaram uma adesão bacteriana mínima após 24 horas e, em 48 horas não observaram formação de um biofilme maduro impedido pela baixa presença de bactérias viáveis. Enquanto que sobre a superfície hidrofóbica do poliuretano observaram que após 12-24 horas aumentou a proliferação de $S$. epidermidis e, após 48 horas observaram a formação de um biofilme maduro. Os autores concluíram que a adesão inicial e formação do biofilme por S. epidermidis pode ser influenciada pela superfície do material.

Baillif et al. (2008) compararam in vitro a aderência e formação de biofilme de Staphylococcus epidermidis sobre diferentes tipos de lentes intra-oculares: polimetilmetacrilato (PMMA), silicone, acrílico hidrofílico e acrílico hidrofóbico. As lentes foram incubadas com a suspensão do $S$. epidermidis, por 12, 16, 24, 40, 48, 60 e 72 horas. Após os períodos de incubação as lentes, foram removidas da suspensão e preparadas para avaliar o número de colônias que aderiram sobre os biomaterias. Houve formação de biofilme em todas as lentes intra-oculares analisadas. A aderência do $S$. epidermidis foi maior nas lentes de acrílico hidrofóbico. Houve diferença estatisticamente significante na capacidade de aderência do $S$. epidermidis sobre as lentes intra-oculares. Concluíram que a aderência do $S$. epidermidis nas lentes intra-oculares é influenciada pelo tipo de material da lente.

Como a formação de biofilme está relacionada com mais de $65 \%$ das infecções hospitalares, o objetivo deste estudo é comparar a formação de biofilme em polímeros usados em lifting facial. 


\section{1 - Geral}

Comparar a formação de biofilme sobre polímeros (poliuretano de origem vegetal - extraído do óleo de Ricinus communis e fios de polipropileno) usados no lifting facial.

\section{2 - Específica}

Avaliar quantitativamente a viabilidade das células em biofilme por cultura.

Avaliar qualitativamente a aderência bacteriana e formação de biofilme sobre a superfície dos polímeros por observação microscópica (microscópio eletrônico de varredura).

Avaliar a superfície topográfica dos polímeros por microscópio eletrônico de varredura (MEV). 


\section{1 - MATERIAL}

\subsection{1 - Seleção dos microrganismos:}

Staphylococcus aureus ATCC 25923

Staphylococcus epidermidis (cepa de campo- isolado de cateter).

Pseudomonas aeruginosa ATCC 27853

S. aureus é uma bactéria encontrada na cavidade nasal e na pele de pessoas normais e também de animais podendo causar diversos tipos de infecções.

S. epidermidis é uma bactéria comum da pele. Presente em infecções associadas a implantes de próteses e de cateteres.

$P$. aeruginosa é normalmente encontrada no solo, água e vegetais. E, em menor freqüência na pele, garganta e fezes de pessoas sadias. Este microrganismo pode causar infecções severas.

\subsection{2 - Biomateriais}

\subsubsection{1 - Fio de poliuretano}

O fio de poliuretano foi desenvolvido a partir de fonte vegetal e recebeu o nome de "fio lifting biológico" (DONTOS, 2006). A base orgânica fio lifting biológico é o óleo extraído da planta Ricinus communis, composto de $89 \%$ do triglicerídeo de ácido ricinoleico. O óleo da planta Ricinus communis, tem estrutura química semelhante aos ácidos graxos essenciais, bem como ao ácido alfa-hidroxinervônico, presente no sistema nervoso central (VILLELA et al., 1978). O poliuretano sintetizada a partir do óleo extraído da planta Ricinus communis é biocompatível, 
como verificado por Azevedo et al.(1997), Cavalca (1998) e Ara (1999).

O fio lifting biológico de $20 \mathrm{~cm}$ de comprimento, $1,5 \mathrm{~cm}$ de largura e $0,5 \mathrm{~mm}$ de espessura apresenta as bordas com garras de $1,0 \mathrm{~mm}$ de comprimento, $0,45 \mathrm{~mm}$ de largura e $0,1 \mathrm{~mm}$ de distância entre si. As garras estão posicionadas a $30^{\circ}$ em relação ao eixo principal e tem por função fixar o fio no local de implante sem necessidade de sutura (Figura 1A-B).
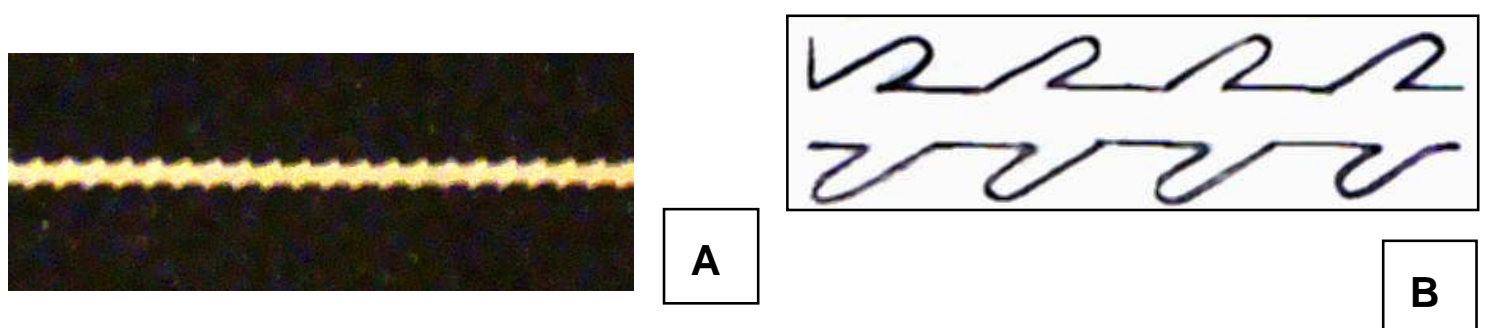

Figura 1 - Fio de poliuretano (A - B).

Estrutura química do poliuretano está apresentado na figura 2:<smiles>[R]NC(=O)O[2H]</smiles>

Figura 2 - Estrutura química dos meros do poliuretano.

\subsubsection{1 - Segmento da amostra de poliuretano}

O fio de poliuretano cedido pela Poliquil Araraquara Polímeros Químicos Ltda, com $20,0 \mathrm{~cm}$ de comprimento esterilizado por raio gama foi seccionado em segmentos de $1,0 \mathrm{~cm}$ de comprimento e esterilizado em autoclave a $121^{\circ} \mathrm{C} / 15 \mathrm{~min}$. Foram utilizados 126 corpos-de-prova. 


\subsubsection{2 - Fio de polipropileno}

O fio de polipropileno é derivado do petróleo e conhecido como fio Russo ou APTOS originário de Moscou/ Rússia, Sulamanidze (2001).

O fio de polipropileno apresenta uma dupla fileira de "garras" dispostas de forma uni e bilateral (Figura $3 \mathrm{~A}-\mathrm{C}$ ).
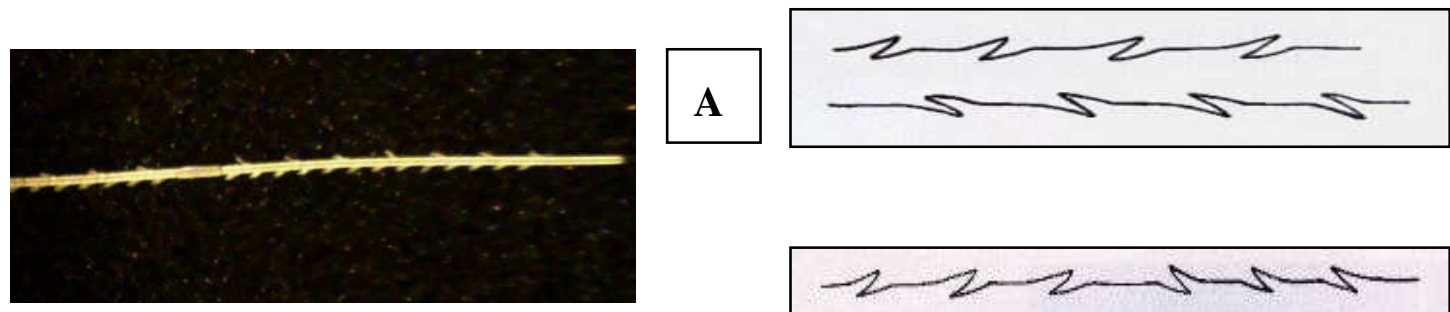

B

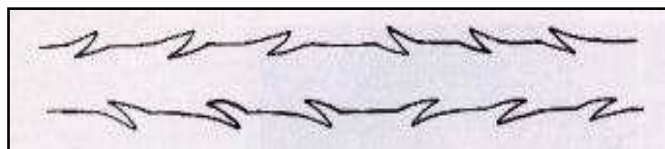

C

Figura 3 - Fio de polipropileno $(A-C)$.

Estrutura química do polipropileno está apresentado na figura 4:

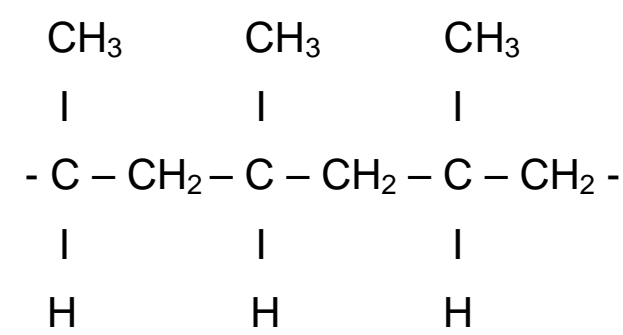

Figura 4 - Estrutura química dos meros do polipropileno.

\subsubsection{1 - Segmento da amostra de polipropileno}

O fio de polipropileno comprado no comércio com $20,0 \mathrm{~cm}$ de comprimento esterilizado por raio gama foi seccionado em segmentos de $1,0 \mathrm{~cm}$ de comprimento e esterilizado em autoclave a $121^{\circ} \mathrm{C}$. Foram utilizados 126 corpos-de-prova. 


\subsection{3 - Distribuição do número de corpos-de-prova de acordo com as provas}

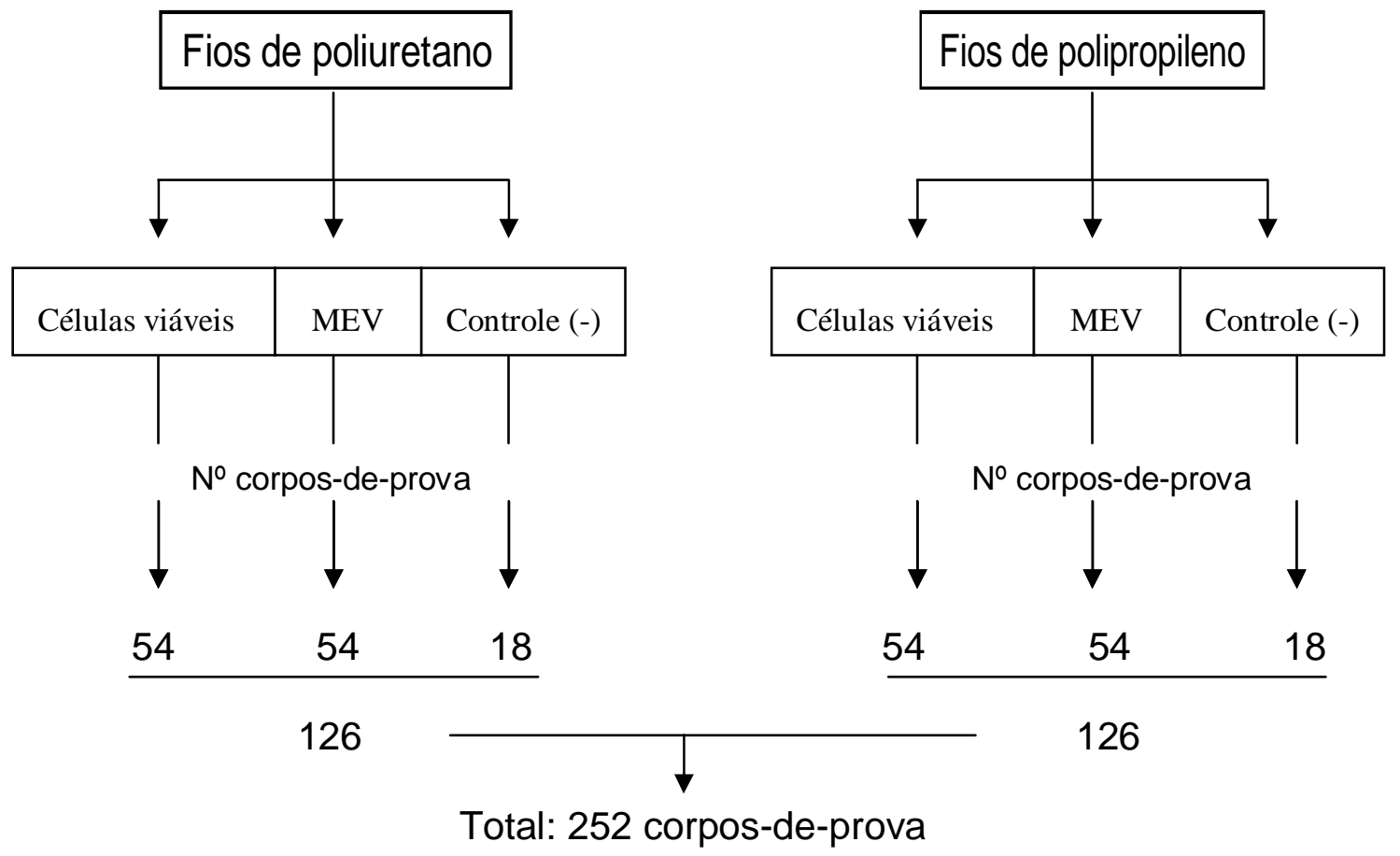

\subsection{4 - Meios de cultura e reagentes}

Os meios de cultura desidratados das marcas comerciais DIFCO ou MERCK foram preparados de acordo com as especificações do fabricante: Caldo MuellerHinton; Tryptic Soy Agar (TSA); Tryptic Soy Broth (TSB);

Os sais e demais reagentes eram de procedência MERCK (Darmastadt, Germany), SIGMA, REAGEN (Quimibrás Indústria Química; Rio de Janeiro, Brasil), BIOBRÁS (Bioquímica do Brasil; Minas Gerais, Brasil) e FLUKA.

4.1.5 - Reagentes utilizados no preparo dos corpos-de-prova (polipropileno e poliuretano) para observações por meio de microscópio eletrônico de varredura (MEV)

Tampão fosfato $0,2 \mathrm{M}$; Tampão fosfato $0,2 \mathrm{M}(\mathrm{pH} 7,1)$; Tampão fosfato $0,1 \mathrm{M}$ (pH 7,1); Solução Tampão 0,1M - glutaraldeído a 2,5\%; Solução de etanol a 15, 30, $50,70,90$ e $100 \%$. 


\section{2 - MÉTODOS}

\subsection{1 - Preparação das suspensões bacterianas (MONTVILLE; SCHAFFNER, 2003)}

As cepas liofilizadas de Staphylococcus aureus (ATCC 25923), Staphylococcus epidermidis (amostra clínica) e Pseudomonas aeruginosa (ATCC 27853) foram preparadas de acordo com as instruções.

Foram semeadas em ágar simples e incubadas por 18 horas a $37^{\circ} \mathrm{C}$. Após esse período foram suspensas em 5,0ml de Tryptic Soy Broth (TSB) até atingir turvação aproximada a 0,5 da escala Mac Farland, cerca de $10^{8} \mathrm{UFC} / \mathrm{ml}$ (Unidades Formadoras de Colônia/mL).

O inóculo preparado foi incubado a $35-37^{\circ} \mathrm{C}$ sob agitação constante de 150rpm em agitador orbital $\left(\right.$ Marconi $\left.^{\Theta}\right)$ por 18-24 horas. A cultura foi centrifugada a 3500rpm por 10 minutos e a biomassa lavada três vezes com 5,0ml de salina tamponada com fosfato - PBS $(\mathrm{pH}-7,2)$.

A biomassa foi suspensa em $3,0 \mathrm{ml}$ de salina tamponada com fosfato (PBS) e a turvação da suspensão foi monitorada por densidade óptica (DO) em espectrofotômetro (FEMTO) até atingir aproximadamente D.O. 0,5 em 660nm, com cerca de $10^{8} \mathrm{UFC} / \mathrm{ml}$ (Unidades Formadoras de Colônia/ml).

\subsection{2 - Formação in vitro de biofilme sobre superfície de poliuretano e polipropileno (PIZZOLITTO et al., 2001)}

Após a preparação do inóculo, $200 \mu$ da suspensão, da ordem de $10^{8}$ células $/ \mathrm{ml}$ de cada um dos microrganismos (Staphylococcus aureus, Staphylococcus epidermidis e Pseudomonas aeruginosa), foi transferida 
individualmente para tubos Falcon (50,0ml) esterilizados, contendo 15,0ml de caldo Mueller-Hinton. Os corpos-de-prova esterilizados e seccionados, de cada biomaterial (polipropileno e poliuretano) foram introduzidos nestes tubos.

Os tubos foram incubados a $37^{\circ} \mathrm{C}$, sob agitação constante de $100 \mathrm{rpm}$ em agitador orbital (Marconi), por 1 hora e 30 minutos; 4; 24; 48; 72 e 120 horas. Após os períodos de incubação, os corpos-de-prova foram retirados e lavados separadamente com salina fisiológica estéril. O ensaio foi realizado em triplicata.

\subsection{3 - Preparação dos corpos-de-prova de poliuretano e polipropileno para análise do biofilme por microscopia eletrônica de varredura - MEV (PIZZOLITTO, 1997)}

Os corpos-de-prova (54 fios de polipropileno e 54 fios de poliuretano) separadamente foram imersos em glutaraldeído a 2,5\% em tampão fosfato $0,1 \mathrm{M}(\mathrm{pH}$ $7,1)$, durante 15 minutos para a fixação dos microrganismos. Desidratação gradual e completa em séries de álcool (15, 30, 50, 70, 90 e 100\%) por 15 minutos cada um. Após a desidratação os corpos-de-prova foram secos em centrífuga a vácuo, com baixa velocidade por 5 minutos, a temperatura de $40^{\circ} \mathrm{C}$ e pressão negativa de $100 \mathrm{mbar}$ e, metalizados com ouro (1KV, 15mHP, 2 minutos) no aparelho Edwards S150B, para tornar a amostra condutora. Em seguida foram montados em suportes metálicos e, foram observados por meio de microscópio eletrônico de varredura JEOL (JSM - T330A), como observado na Figura 5. 


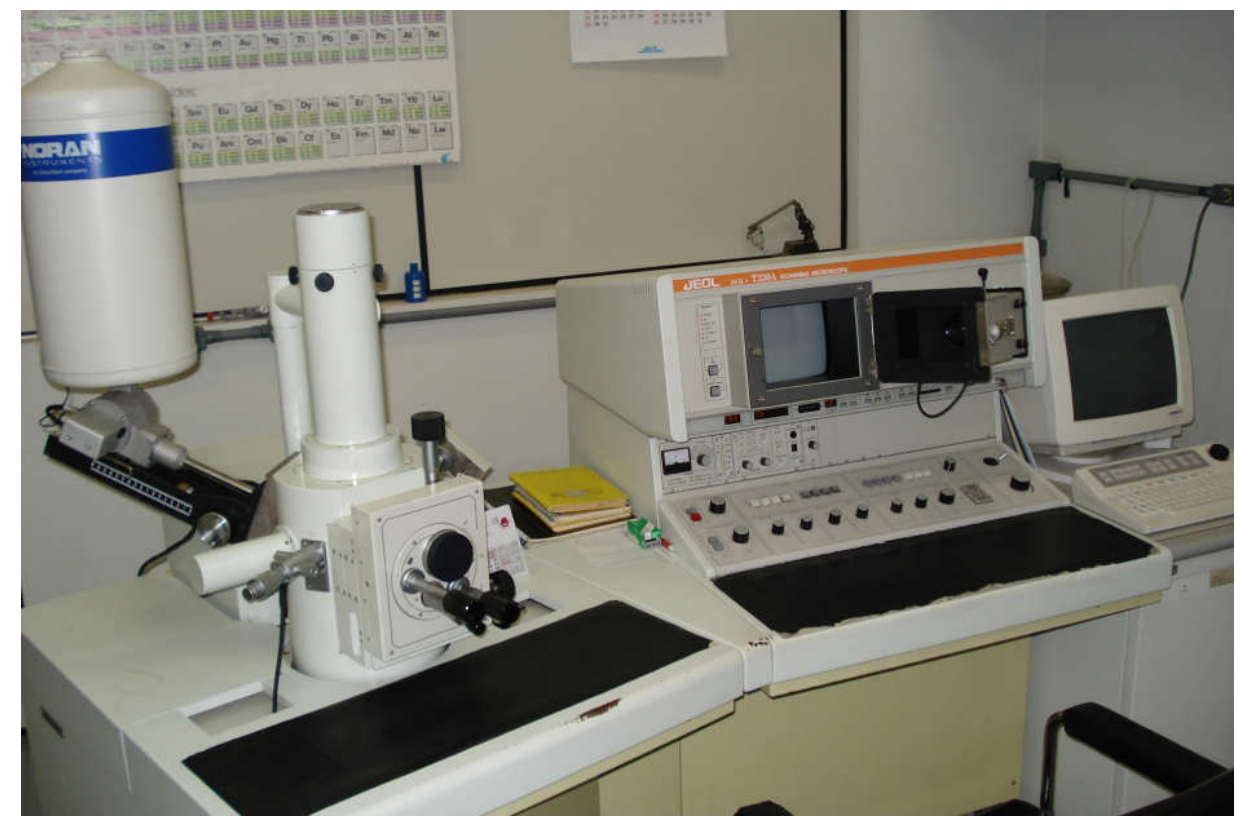

Figura 5 - Microscópio eletrônico de varredura (JEOL-JSM, modelo T330A).

\subsection{4 - Avaliação quantitativa de células bacterianas viáveis dos biofilmes} (MIYANO et al., 2003)

Os corpos-de-prova (54 fios de polipropileno e 54 fios de poliuretano) foram introduzidos, separadamente, em tubos de vidro contendo $5,0 \mathrm{ml}$ de salina fisiológica esterilizada e sonicados em banho de $40 \mathrm{KHz}$ (Figura 6) por 8 minutos, para a recuperação das células bacterianas aderidas sobre a superfície dos corpos-deprova. A seguir, submetidos ao vórtex por 10 segundos. Após este procedimento foram realizadas diluições seriadas $\left(10^{-1}, 10^{-2}\right.$ e $\left.10^{-3}\right)$ de cada amostra em salina fisiológica esterilizada.

A seguir, $0,1 \mathrm{ml}(100 \mu \mathrm{l})$ da diluição $10^{-3}$ de cada amostra foi semeado em toda a superfície da placa $(90 \times 15 \mathrm{~mm})$ com auxílio da alça de Drigalsky, contendo o meio de cultura Tryptic Soy Agar (TSA). As placas foram incubadas a $35-37^{\circ} \mathrm{C}$ em estufa bacteriológica por 24 horas. As colônias crescidas foram contadas e foi 
calculado o total de UFC/ml expressos em logaritmos (log UFC/ml) (Figura 7). As placas adequadas para a contagem devem ter entre 30 a 300 colônias.

Os números em logaritmos foram obtidos por meio da calculadora eletrônica cientifica. $\mathrm{O}$ ensaio foi realizado em triplicata.

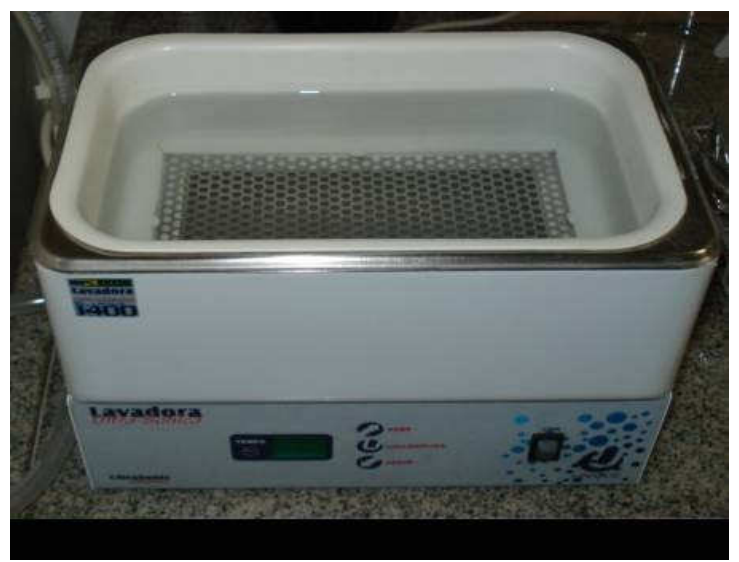

Figura 6 - Banho ultrasônico.

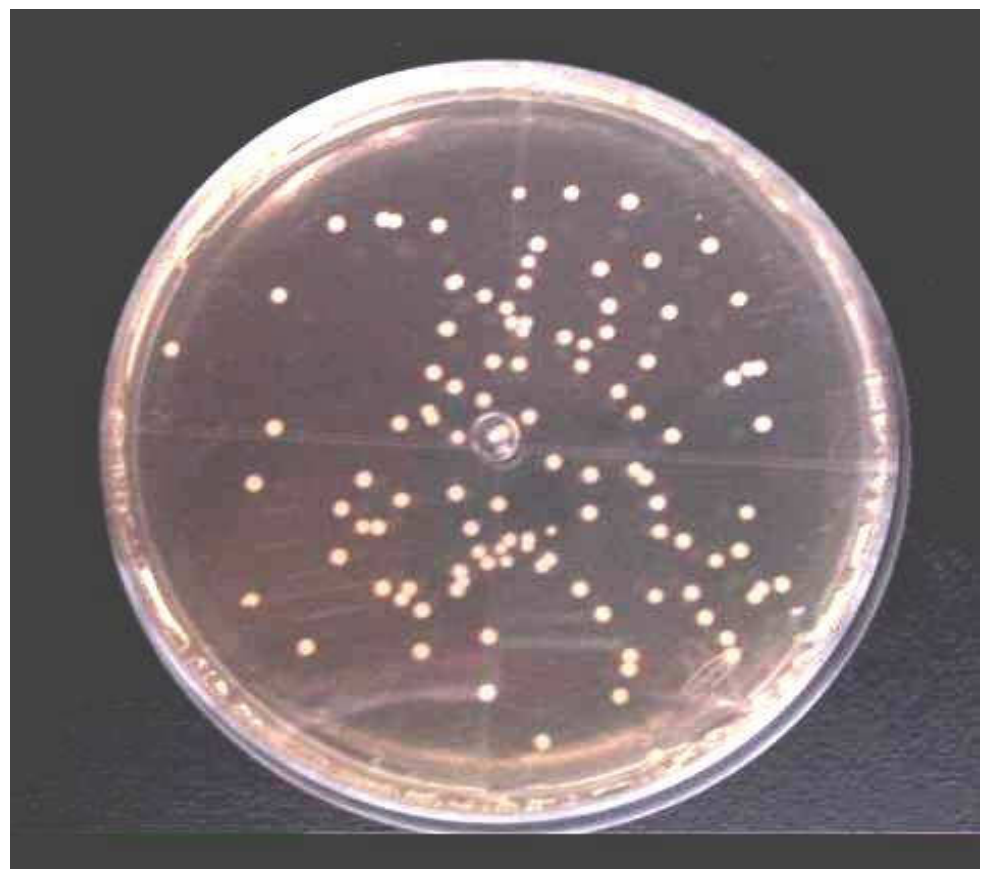

Figura 7 - Unidades formadoras de colônia (UFC/ml). 


\subsubsection{1 - Diluições seriadas (TORTORA et al., 2000; MIYANO et al., 2003)}

Após o procedimento de sonicação e vórtex dos corpos-de-prova (polipropileno e poliuretano), 1,0mL da suspensão bacteriana foi transferido para um tubo de cultura $(18 \times 180 \mathrm{~mm})$ contendo $9,0 \mathrm{~mL}$ de solução salina esterilizada (diluição 1:10 ou $10^{-1}$ ). A suspensão foi homogeneizada em agitador de tubos. Após este procedimento $1,0 \mathrm{~mL}$ da diluição anterior foi transferido para outro tubo de cultura com 9,0mL de solução salina esterilizada obtendo-se uma diluição $1: 100$ ou $10^{-2}$. $1,0 \mathrm{ml}$ da diluição anterior $\left(10^{-2}\right)$ foi transferido para outro tubo de cultura com $9,0 \mathrm{ml}$ de solução salina esterilizada obtendo-se uma diluição 1:1000 ou 10-3.

Diluições maiores podem ser obtidas tomando-se 1,0mL de cada diluição sucessiva e colocando em tubos de cultura com 9,0mL de solução salina, até se atingir a diluição desejada, como representado na Figura 8.

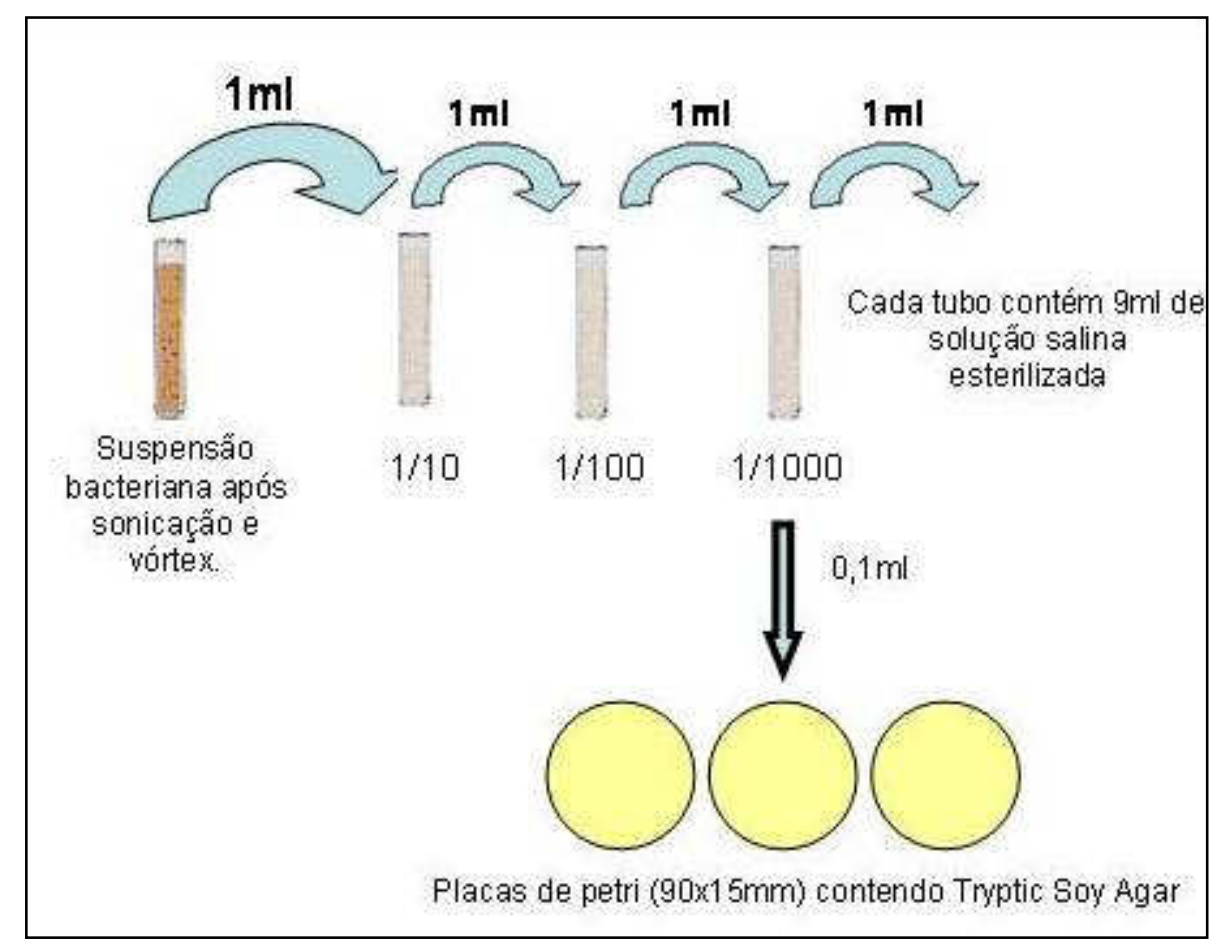

Figura 8 - Representação esquemática do método de diluição seriada. 


\subsubsection{2. - Método do espalhamento em placa (plaqueamento em superfície)}

Após a diluição seriada, da amostra na diluição $10^{-3}$, pipetou-se $0,1 \mathrm{ml}$ $(100 \mu l)$ em placas de petri $(90 \times 15 \mathrm{~mm})$ contendo o meio sólido Tryptic Soy Agar (TSA). O espalhamento do inóculo se fez em toda a superfície da placa, com auxilio da alça de Drigalsky. As placas de petri tampadas foram invertidas e incubadas em estufas bacteriológicas a $37^{\circ} \mathrm{C}$. Após 24 horas de incubação as colônias crescidas foram contadas e o resultado da diluição foi registrado e multiplicado pelo fator da diluição, representado na Figura 9. 


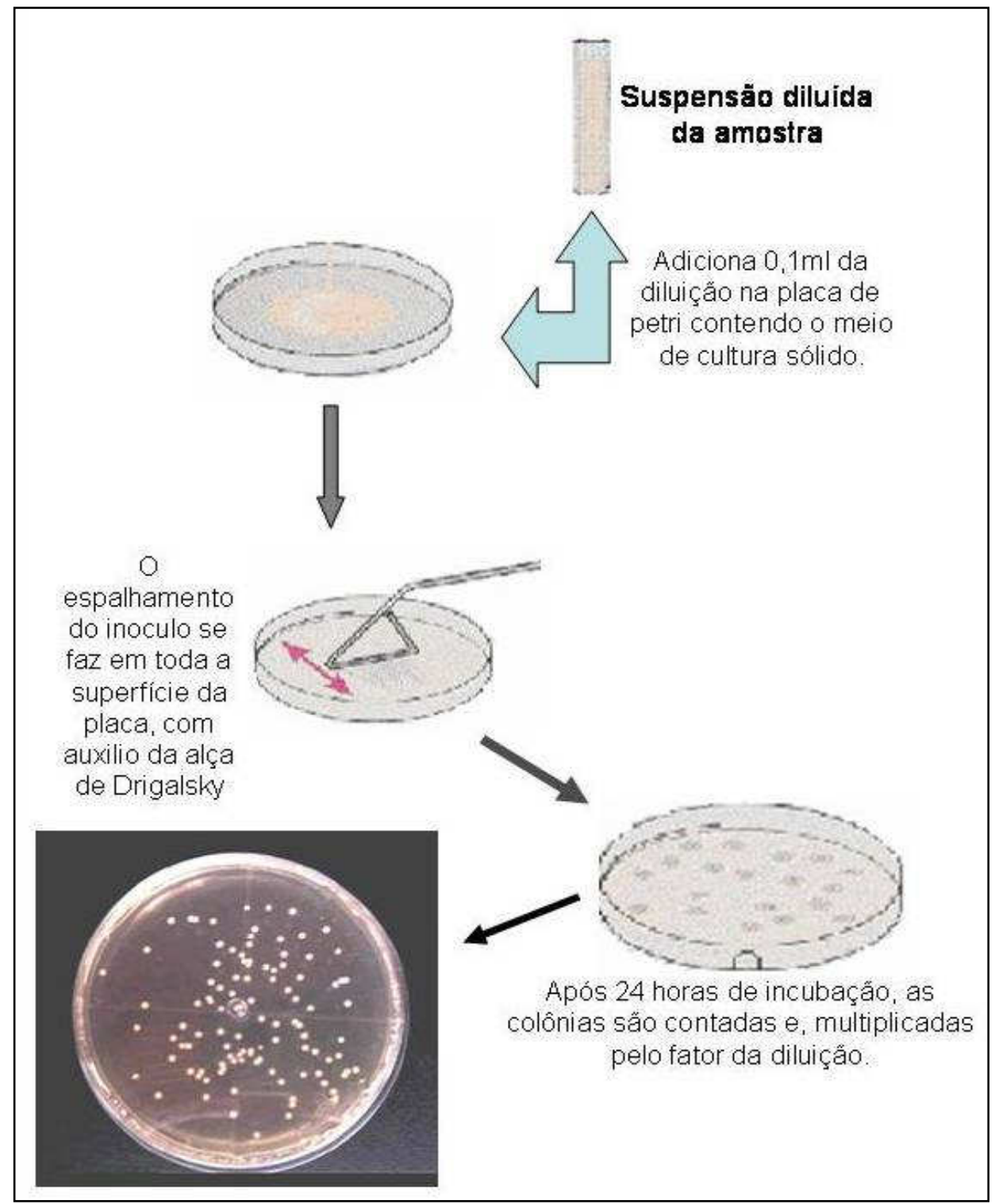

Figura 9 - Representação esquemática do método de plaqueamento em superfície.

\subsection{5 - Análises estatísticas}

A análise estatística foi realizada objetivando-se se existia ou não diferença estatisticamente significante entre a aderência dos microrganismos sobre os fios de polímeros.

Para análise estatística dos dados obtidos com a quantificação de células viáveis, foram realizadas as seguintes medidas estatísticas: média, desvio padrão e 
coeficiente de variação e, foi utilizada a análise da variância univariada (ANOVA). A significância estatística foi definida como $p<0,05$. 


\section{1 - Células viáveis}

5.1.1 - Staphylococcus aureus em contato com a superfície de poliuretano e polipropileno.

A Tabela 1 apresenta a distribuição do número de Unidades Formadoras de Colônia (UFC/ml) do S. aureus recuperadas da superfície do poliuretano.

Tabela 1. Distribuição células viáveis de $S$. aureus recuperadas após contato com a superfície do poliuretano nos tempos de 1,5-120 horas.

\begin{tabular}{lccccc}
\hline Biomaterial Microrganismo & $\begin{array}{c}\text { Tempo de } \\
\text { incubação } \\
\text { (horas) }\end{array}$ & UFC/ml & $\begin{array}{c}\text { UFC/ml x } \\
\text { fator } \\
\text { diluição } \\
(\mathbf{x 1 0 0 0})\end{array}$ & $\begin{array}{c}\text { UFC/ml } \\
(\mathbf{x 1 0 0 0})\end{array}$ \\
\hline Poliuretano & S. aureus & $\begin{array}{c}1 \text { hora e } 30 \\
\text { minutos }\end{array}$ & 10 & 10.000 & $1 \times 10^{4}$ \\
& 4 & 100 & 100.000 & $10 \times 10^{4}$ \\
& 24 & 300 & 300.000 & $30 \times 10^{4}$ \\
& 48 & 400 & 400.000 & $40 \times 10^{4}$ \\
& 72 & 400 & 400.000 & $40 \times 10^{4}$ \\
& 120 & 500 & 500.000 & $50 \times 10^{4}$ \\
\hline
\end{tabular}

A Tabela 2 apresenta a distribuição do número de Unidades Formadoras de Colônia (UFC/ml) do S. aureus recuperadas da superfície do polipropileno. 
Tabela 2. Distribuição células viáveis de $S$. aureus recuperadas após contato com a superfície do polipropileno nos tempos de 1,5-120 horas.

\begin{tabular}{lccccc}
\hline Biomaterial & Microrganismo & $\begin{array}{c}\text { Tempo de } \\
\text { incubação } \\
\text { (horas) }\end{array}$ & UFC/ml & $\begin{array}{c}\text { UFC/ml x } \\
\text { fator } \\
\text { diluição } \\
(\times 1000)\end{array}$ & $\begin{array}{c}\text { UFC/ml } \\
(\mathbf{x 1 0 0 0})\end{array}$ \\
\hline Polipropileno & S. aureus & $\begin{array}{c}\text { 1 hora e } 30 \\
\text { minutos }\end{array}$ & 20 & 20.000 & $2 \times 10^{4}$ \\
& 4 & 60 & 60.000 & $6 \times 10^{4}$ \\
& 24 & 700 & 700.000 & $70 \times 10^{4}$ \\
& 48 & 2000 & 2.000 .000 & $200 \times 10^{4}$ \\
& 72 & 2500 & 2.500 .000 & $250 \times 10^{4}$ \\
& 120 & 2500 & 2.500 .000 & $250 \times 10^{4}$ \\
\hline
\end{tabular}

5.1.2 - Staphylococcus epidermidis em contato com a superfície de poliuretano e polipropileno.

A Tabela 3 apresenta a distribuição do número de Unidades Formadoras de Colônia (UFC/ml) do S. epidermidis recuperadas da superfície do poliuretano. 
Tabela 3. Distribuição células viáveis de $S$. epidermidis recuperadas após contato com a superfície do poliuretano nos tempos de 1,5-120 horas.

\begin{tabular}{lccccc}
\hline Biomaterial & Microrganismo & $\begin{array}{c}\text { Tempo de } \\
\text { incubação } \\
\text { (horas) }\end{array}$ & UFC/ml & $\begin{array}{c}\text { UFC/ml x } \\
\text { fator } \\
\text { diluição } \\
(\mathbf{x 1 0 0 0})\end{array}$ & $\begin{array}{c}\text { UFC/ml } \\
(\mathbf{x 1 0 0 0})\end{array}$ \\
\hline Poliuretano & S. epidermidis & $\begin{array}{c}\text { 1 hora e } 30 \\
\text { minutos }\end{array}$ & 10 & 10.000 & $1 \times 10^{4}$ \\
& 4 & 100 & 100.000 & $10 \times 10^{4}$ \\
& 24 & 150 & 150.000 & $15 \times 10^{4}$ \\
& 48 & 300 & 300.000 & $30 \times 10^{4}$ \\
& 72 & 50 & 50.000 & $5 \times 10^{4}$ \\
& 120 & 40 & 40.000 & $4 \times 10^{4}$ \\
\hline
\end{tabular}

A Tabela 4 apresenta a distribuição do número de Unidades Formadoras de Colônia (UFC/ml) do S. epidermidis recuperadas da superfície do polipropileno.

Tabela 4. Distribuição células viáveis de $S$. epidermidis recuperadas após contato com a superfície do polipropileno nos tempos de 1,5-120 horas.

\begin{tabular}{lccccc}
\hline Biomaterial & Microrganismo & $\begin{array}{c}\text { Tempo de } \\
\text { incubação } \\
\text { (horas) }\end{array}$ & UFC/ml & $\begin{array}{c}\text { UFC/ml x } \\
\text { fator } \\
\text { diluição } \\
(\times 1000)\end{array}$ & $\begin{array}{c}\text { UFC/ml } \\
(\mathbf{x 1 0 0 0})\end{array}$ \\
\hline Polipropileno & S. epidermidis & $\begin{array}{c}1 \text { hora e } 30 \\
\text { minutos }\end{array}$ & 10 & 10.000 & $1 \times 10^{4}$ \\
& 4 & 30 & 30.000 & $3 \times 10^{4}$ \\
& 24 & 300 & 300.000 & $30 \times 10^{4}$ \\
& 48 & 70 & 70.000 & $7 \times 10^{4}$ \\
& 72 & 80 & 80.000 & $8 \times 10^{4}$ \\
& 120 & 100 & 100.000 & $10 \times 10^{4}$ \\
\hline
\end{tabular}




\subsection{3 - Pseudomonas aeruginosa em contato com a superfície de poliuretano e} polipropileno.

A Tabela 5 apresenta a distribuição do número de Unidades Formadoras de Colônia (UFC/ml) de P. aeruginosa recuperadas da superfície do poliuretano.

Tabela 5. Distribuição células viáveis de $P$. aeruginosa recuperadas após contato com a superfície do poliuretano nos tempos de 1,5-120 horas.

\begin{tabular}{lccccc}
\hline Biomaterial & Microrganismo & $\begin{array}{c}\text { Tempo de } \\
\text { incubação } \\
\text { (horas) }\end{array}$ & UFC/ml & $\begin{array}{c}\text { UFC/ml x } \\
\text { fator } \\
\text { diluição } \\
(\mathbf{x 1 0 0 0})\end{array}$ & $\begin{array}{c}\text { UFC/ml } \\
(\mathbf{x 1 0 0 0})\end{array}$ \\
\hline Poliuretano & P. aeruginosa & $\begin{array}{c}\text { 1 hora e } 30 \\
\text { minutos }\end{array}$ & 100 & 100.000 & $10 \times 10^{4}$ \\
& 4 & 1300 & 1.300 .000 & $130 \times 10^{4}$ \\
& 24 & 4000 & 4.000 .000 & $400 \times 10^{4}$ \\
& 48 & 5000 & 5.000 .000 & $500 \times 10^{4}$ \\
& 72 & 5500 & 5.500 .000 & $550 \times 10^{4}$ \\
& 120 & 3000 & 3.000 .000 & $300 \times 10^{4}$ \\
\hline
\end{tabular}

A Tabela 6 apresenta a distribuição do número de Unidades Formadoras de Colônia (UFC/ml) de P. aeruginosa recuperadas da superfície do polipropileno. 
Tabela 6. Distribuição células viáveis de $P$. aeruginosa recuperadas após contato com a superfície do polipropileno nos tempos de 1,5-120 horas.

\begin{tabular}{cccccc}
\hline Biomaterial & Microrganismo & $\begin{array}{c}\text { Tempo de } \\
\text { incubação } \\
\text { (horas) }\end{array}$ & UFC/ml & $\begin{array}{c}\text { UFC/ml x } \\
\text { fator } \\
\text { diluição } \\
(\mathbf{x 1 0 0 0 )}\end{array}$ & $\begin{array}{c}\text { UFC/ml } \\
(\mathbf{x 1 0 0 0})\end{array}$ \\
\hline Polipropileno & P. aeruginosa & $\begin{array}{c}\text { 1 hora e 30 } \\
\text { minutos }\end{array}$ & 600 & 600.000 & $60 \times 10^{4}$ \\
& 4 & 1700 & 1.700 .000 & $170 \times 10^{4}$ \\
& 24 & 5500 & 5.500 .000 & $550 \times 10^{4}$ \\
& 48 & 6000 & 6.000 .000 & $600 \times 10^{4}$ \\
& 72 & 6600 & 6.600 .000 & $660 \times 10^{4}$ \\
& 120 & 4000 & 4.000 .000 & $400 \times 10^{4}$ \\
\hline
\end{tabular}

5.1.4 - Células viáveis de Staphylococcus aureus, Staphylococcus epidermidis e Pseudomonas aeruginosa recuperadas após o contato com a superfície de poliuretano e polipropileno evidenciado por unidades formadoras de colônia em $\log / \mathrm{ml}$.

A Tabela 7 apresenta a distribuição da contagem de células viáveis do $S$. aureus, $S$. epidermidis e $P$. aeruginosa recuperadas após contato com as superfícies de poliuretano e polipropileno nos tempos (1,5-120 horas) em log/ml. 
Tabela 7. Distribuição da quantificação de células viáveis de $S$. aureus, $S$. epidermidis e $P$. aeruginosa recuperadas da superfície de contato de poliuretano e polipropileno.

\begin{tabular}{lcccc}
\hline \multirow{2}{*}{ Biomateriais } & \multicolumn{4}{c}{ log UFC/ml (média \pm desvio padrão) } \\
\hline Poliuretano & 1,5 & $4,00 \pm 0,0$ & $4,07 \pm 0,10$ & $5,08 \pm 0,14$ \\
& 4 & $5,04 \pm 0,04$ & $5,01 \pm 0,08$ & $6,12 \pm 0,01$ \\
& 24 & $5,48 \pm 0,02$ & $5,20 \pm 0,16$ & $6,60 \pm 0,01$ \\
& 48 & $5,58 \pm 0,10$ & $5,47 \pm 0,05$ & $6,69 \pm 0,04$ \\
& 72 & $5,56 \pm 0,10$ & $4,69 \pm 0,07$ & $6,68 \pm 0,03$ \\
& 120 & $5,77 \pm 0,04$ & $4,61 \pm 0,03$ & $6,52 \pm 0,04$ \\
& & & & \\
\hline & & & & \\
& 1,5 & $4,24 \pm 0,20$ & $4,14 \pm 0,14$ & $5,77 \pm 0,05$ \\
& 4 & $4,82 \pm 0,07$ & $4,46 \pm 0,10$ & $6,23 \pm 0,02$ \\
& 24 & $5,74 \pm 0,07$ & $5,50 \pm 0,04$ & $6,76 \pm 0,05$ \\
& 48 & $6,43 \pm 0,07$ & $4,85 \pm 0,04$ & $6,78 \pm 0,04$ \\
& 72 & $6,41 \pm 0,10$ & $4,95 \pm 0,04$ & $6,82 \pm 0,05$ \\
& 120 & $6,44 \pm 0,07$ & $5,07 \pm 0,11$ & $6,57 \pm 0,10$ \\
\hline
\end{tabular}

A quantificação de células viáveis apresentadas na Tabela 7 mostrou diferença estatisticamente significante $(p<0,05)$ em relação as médias $(\log / \mathrm{ml})$ por intervalos de tempo, isto é, houve diferença na aderência de cada bactéria ( $S$. aureus, $S$. epidermidis e $P$. aeruginosa) sobre a superfície dos fios de polímeros (poliuretano e polipropileno). A aderência das bactérias sobre os polímeros foi observada em 1 hora e 30 minutos, com um pico máximo de 48 horas de incubação. $P$. aeruginosa foi o microrganismo que apresentou uma maior aderência e formação de biofilme em ambos os polímeros estudados. 
5.2 - Contagem das células viáveis de Staphylococcus aureus, Staphylococcus epidermidis e Pseudomonas aeruginosa apresentada em gráfico que mostra os intervalos de tempo de contato com poliuretano e polipropileno evidenciado por unidades formadoras de colônia em log/ml.

5.2.1 - Em gráfico mostra a contagem de células viáveis de Staphylococcus aureus recuperadas após o contato com o poliuretano e polipropileno.

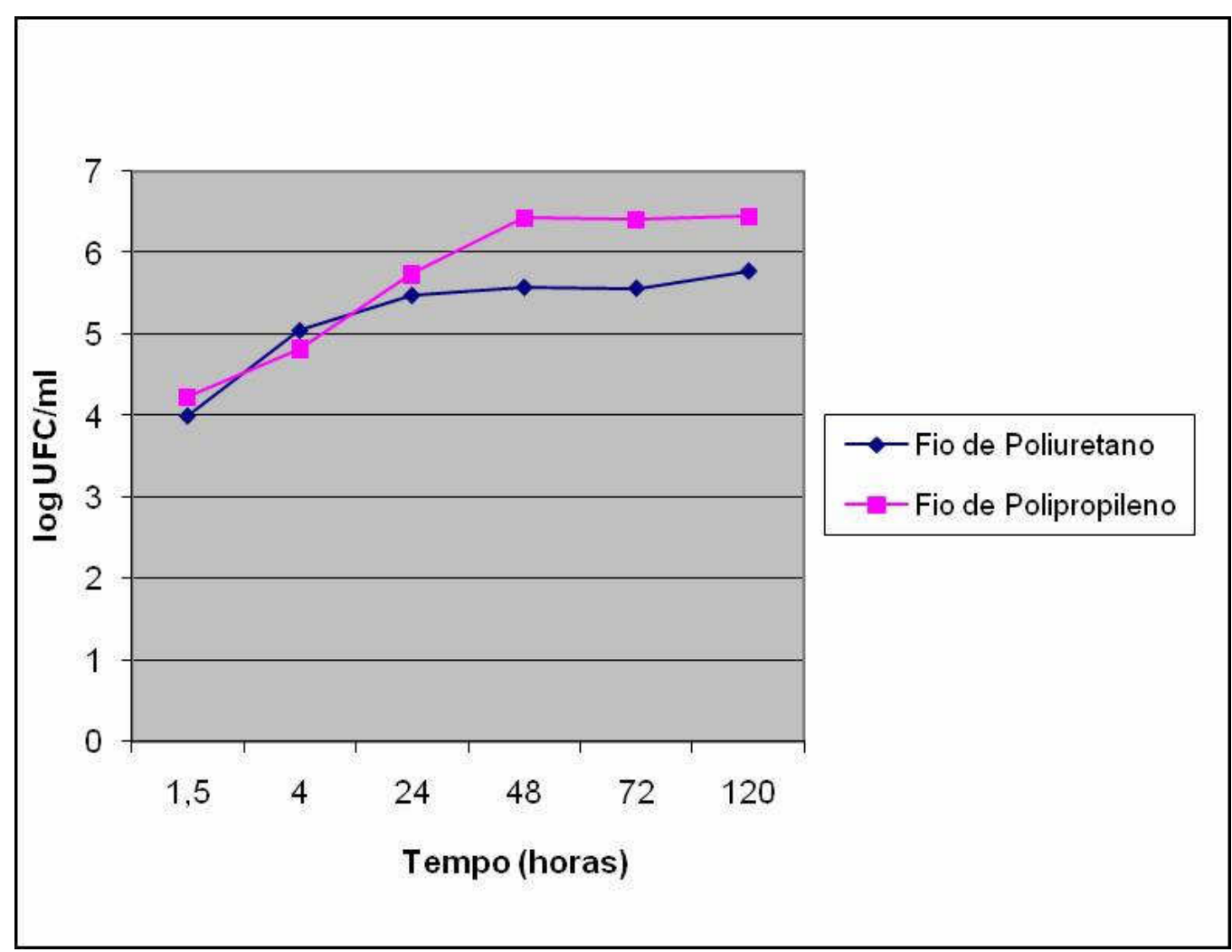

Figura 10 - Número de células viáveis durante a formação de biofilme por S. aureus nos períodos de 1,5 - 120 horas de incubação em caldo Mueller-Hinton.

A aderência de $S$. aureus sobre a superfície dos fios de polímeros (poliuretano e polipropileno) não apresentou diferença estatisticamente significante $(p<0,05)$, isto é, não houve diferença na aderência e formação de biofilme do $S$. aureus em ambos os polímeros. 


\subsection{2 - Em gráfico mostra a contagem de células viáveis de Staphylococcus} epidermidis recuperadas após o contato com o poliuretano e polipropileno.

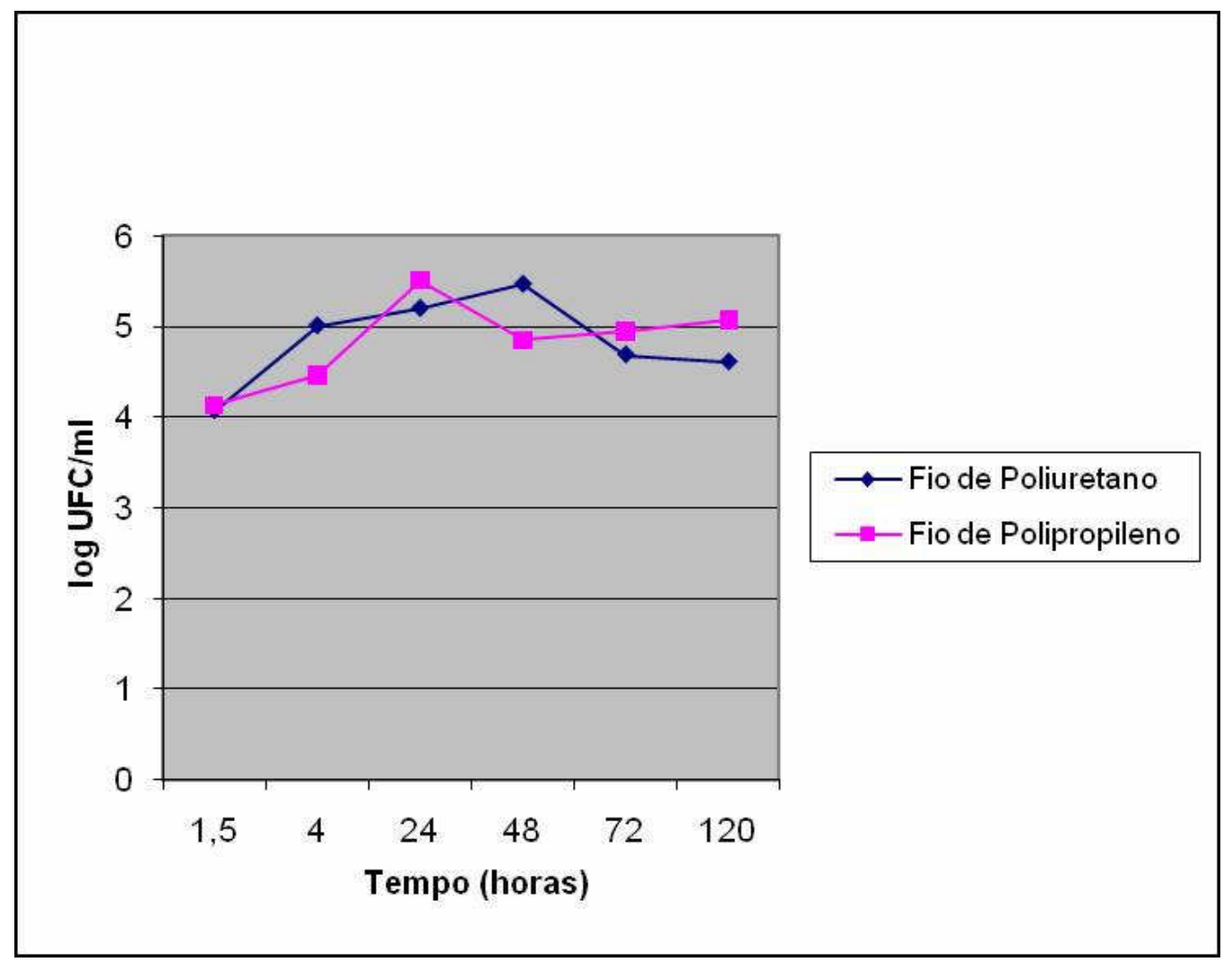

Figura 11 - Número de células viáveis durante a formação de biofilme por S. epidermidis no período de 1,5 - 120 horas de incubação em caldo Mueller-Hinton.

A aderência de $S$. epidermidis sobre a superfície dos fios de polímeros (poliuretano e polipropileno) não apresentou diferença estatisticamente significante $(p<0,05)$, isto é, não houve diferença na aderência e formação de biofilme do $S$. epidermidis em ambos os polímeros. 
5.2.3 - Em gráfico mostra a contagem de células viáveis de Pseudomonas aeruginosa recuperadas após o contato com o poliuretano e polipropileno.

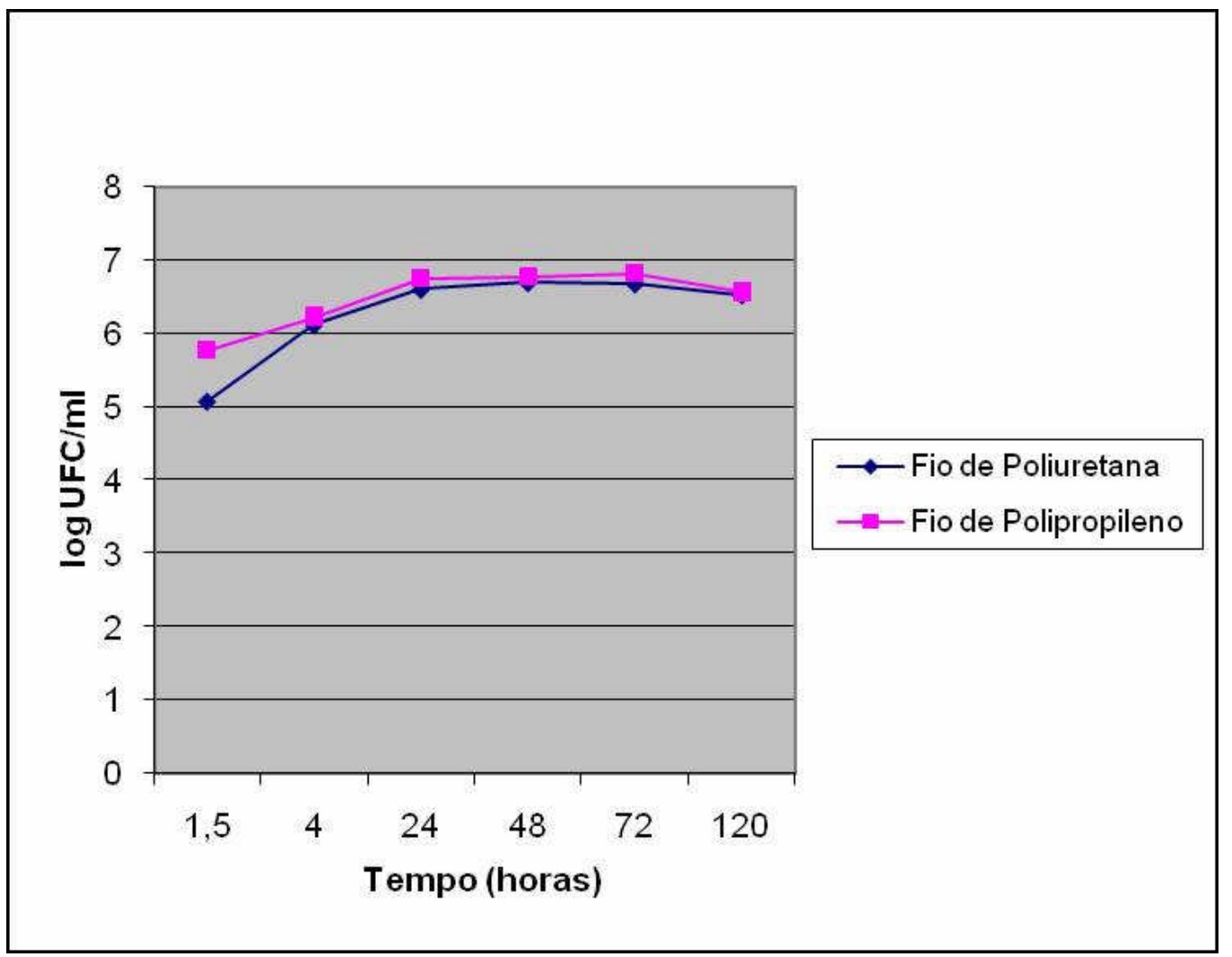

Figura 12 - Número de células viáveis durante a formação de biofilme por $P$. aeruginosa no período de 1,5-120 horas de incubação em caldo Mueller-Hinton.

A aderência da $P$. aeruginosa sobre a superfície dos fios de polímeros (poliuretano e polipropileno) não apresentou diferença estatisticamente significante $(p<0,05)$, isto é, não houve diferença na aderência e formação de biofilme da $P$. aeruginosa em ambos os polímeros.

5.3 - Microscopia Eletrônica de Varredura (MEV): Observação da formação de biofilme de Staphylococcus aureus, Staphylococcus epidermidis e Pseudomonas aeruginosa sobre a superfície do poliuretano e polipropileno. 


\subsection{1 - Superfície do poliuretano.}

A Figura 13 mostra a superfície do corpo-de-prova do poliuretano antes da formação de biofilme (controle negativo).

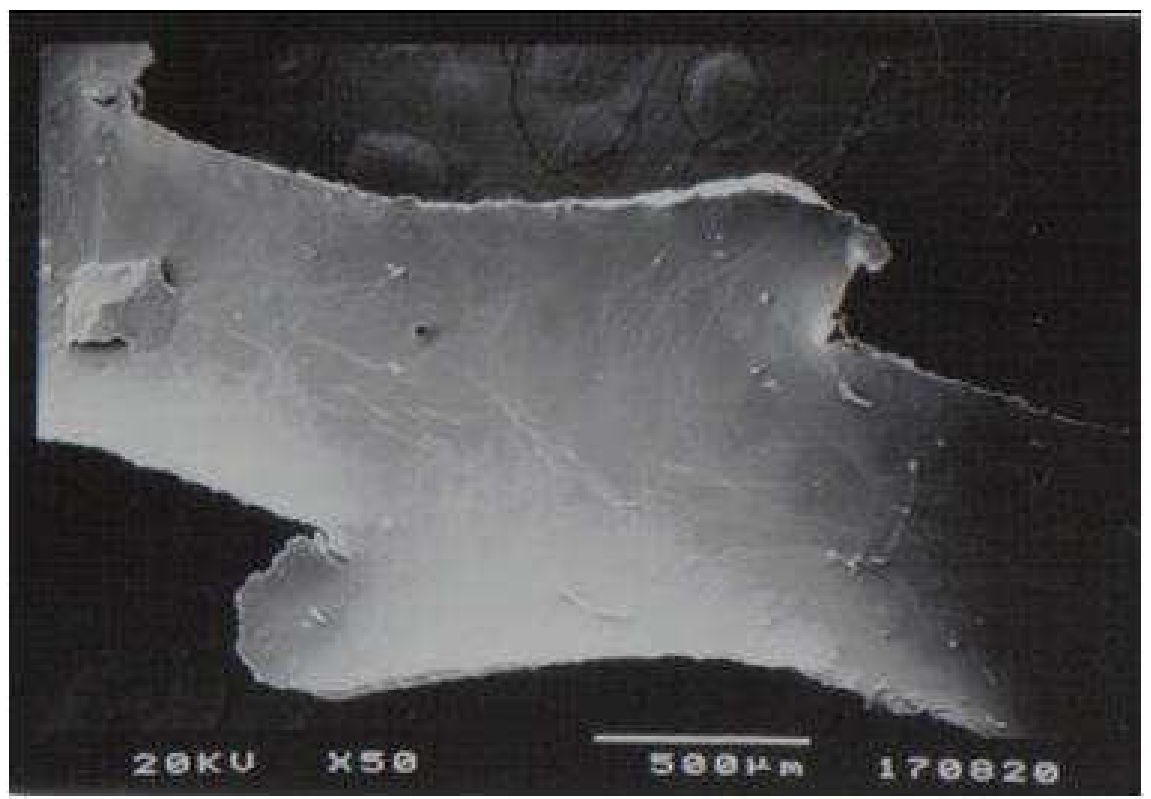

Figura 13 - Eletromicrografia de varredura (50x) do fio de poliuretano (controle negativo) (Microscópio eletrônico de varredura, JEOL-JSM, modelo T330A). 


\subsubsection{1 - Superfície do poliuretano em contato com S. aureus.}

Figura 14 eletromicrografia de varredura da superfície do corpo-de-prova de

poliuretano após a aderência e formação de biofilme de $S$. aureus, em 1,5 - 120 horas de incubação em caldo Mueller-Hinton.
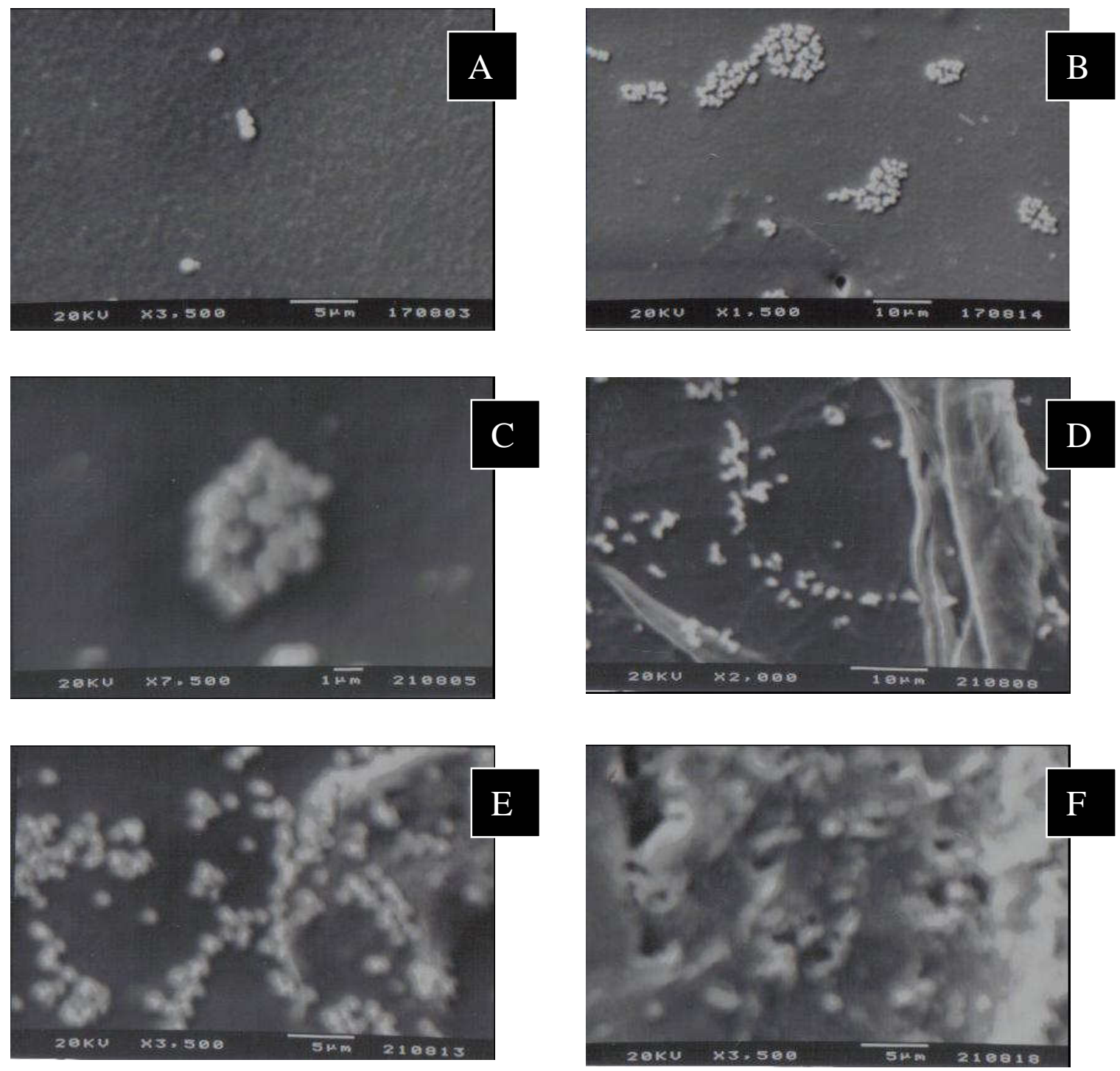

Figura 14 - Eletromicrografia de varredura da aderência e formação de biofilme de $S$. aureus sobre a superfície do poliuretano em: (A) 1,5 horas de incubação (7500x), (B) 4 horas de incubação (1500x), (C) 24 horas de incubação (3500x), (D) 48 horas de incubação (2000x), (E) 72 horas de incubação (3500x) e (F) 120 horas de incubação (3500x) (Microscópio eletrônico de varredura, JEOL-JSM, modelo T330A). 
A aderência do $S$. aureus sobre a superfície do poliuretano foi observada em 1 hora e 30 minutos de incubação, mostrando uma aderência inicial, com início da multiplicação celular e produção de polissacarídeo extracelular. Em 4 horas de incubação observa-se um agrupamento celular. Em 24-72 horas de incubação observa-se um crescimento e maturação do biofilme. Com 120 horas de incubação observa-se um biofilme maduro representado por uma massa amorfa, isto é, biofilme maduro envolto por polissacarídeo extracelular. 


\subsubsection{2 - Superfície do poliuretano em contato com S. epidermidis.}

Figura 15 eletromicrografia de varredura da superfície do corpo-de-prova de poliuretano após a aderência e formação de biofilme de $S$. epidermidis, em 1,5 - 120 horas de incubação em caldo Mueller-Hinton.
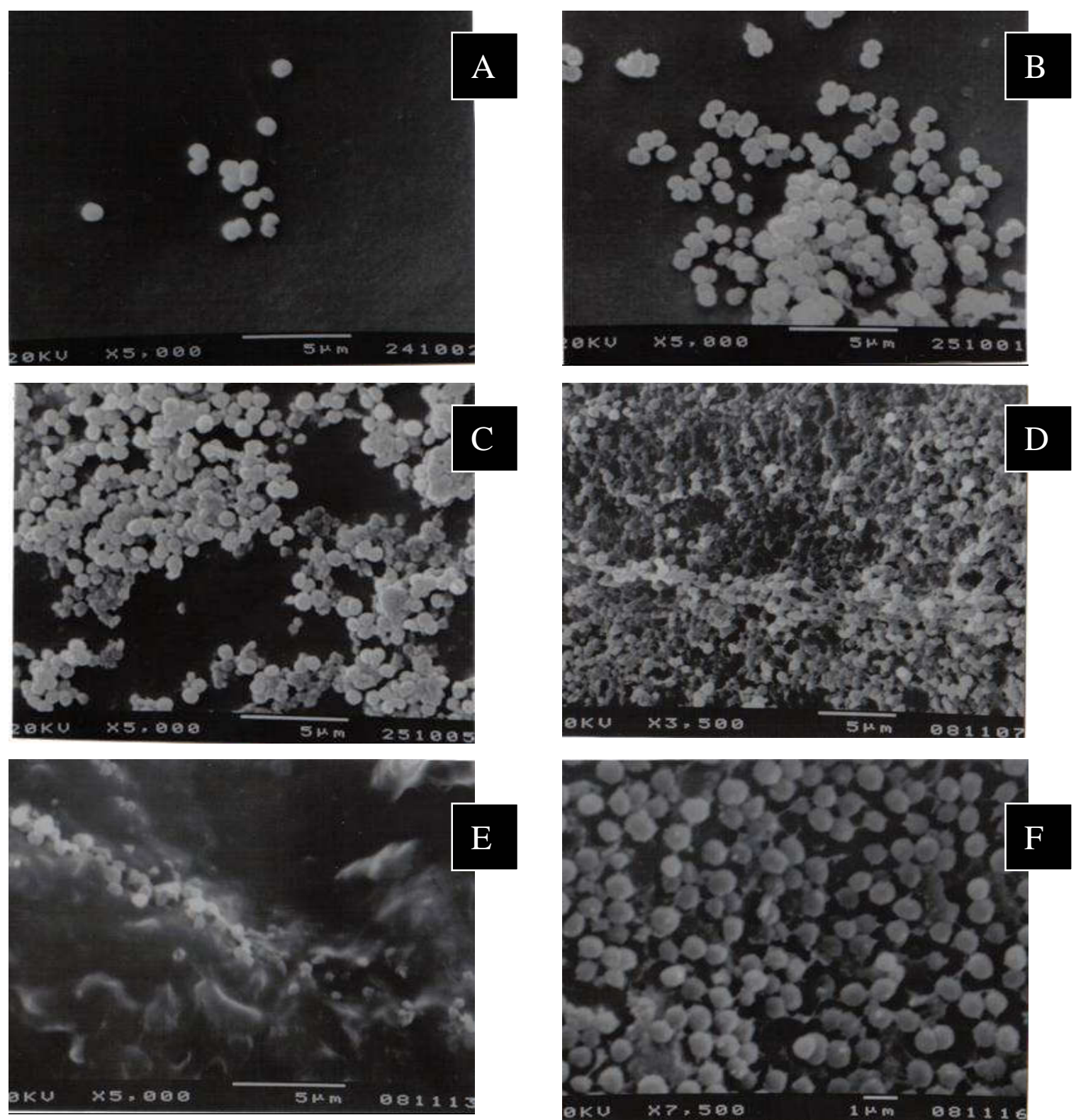

Figura 15 - Eletromicrografia de varredura da aderência e formação de biofilme de $S$. epidermidis sobre a superfície do poliuretano em: (A) 1,5 horas de incubação (5000x), (B) 4 horas de incubação (5000x), (C) 24 horas de incubação (5000x), (D) 48 horas de incubação (3500x), (E) 72 horas de incubação (5000x) e (F) 120 horas de incubação (7500x) (Microscópio eletrônico de varredura, JEOL-JSM, modelo T330A). 
A aderência do $S$. epidermidis sobre a superfície do poliuretano foi observada em 1 hora e 30 minutos de incubação, mostrando uma aderência inicial, com início da divisão binária da célula e produção de polissacarídeo extracelular. Em 4 horas de incubação observa-se multiplicação celular e crescimento do biofilme. Em 24-72 horas de incubação observa-se um biofilme maduro. Em 120 horas de incubação observam-se ligações intercelular das células no biofilme. 


\subsubsection{3 - Superfície do poliuretano em contato com $P$. aeruginosa.}

Figura 16 eletromicrografia de varredura da superfície do corpo-de-prova de poliuretano após a aderência e formação de biofilme de $P$. aeruginosa, em 1,5 - 120 horas de incubação em caldo Mueller-Hinton.
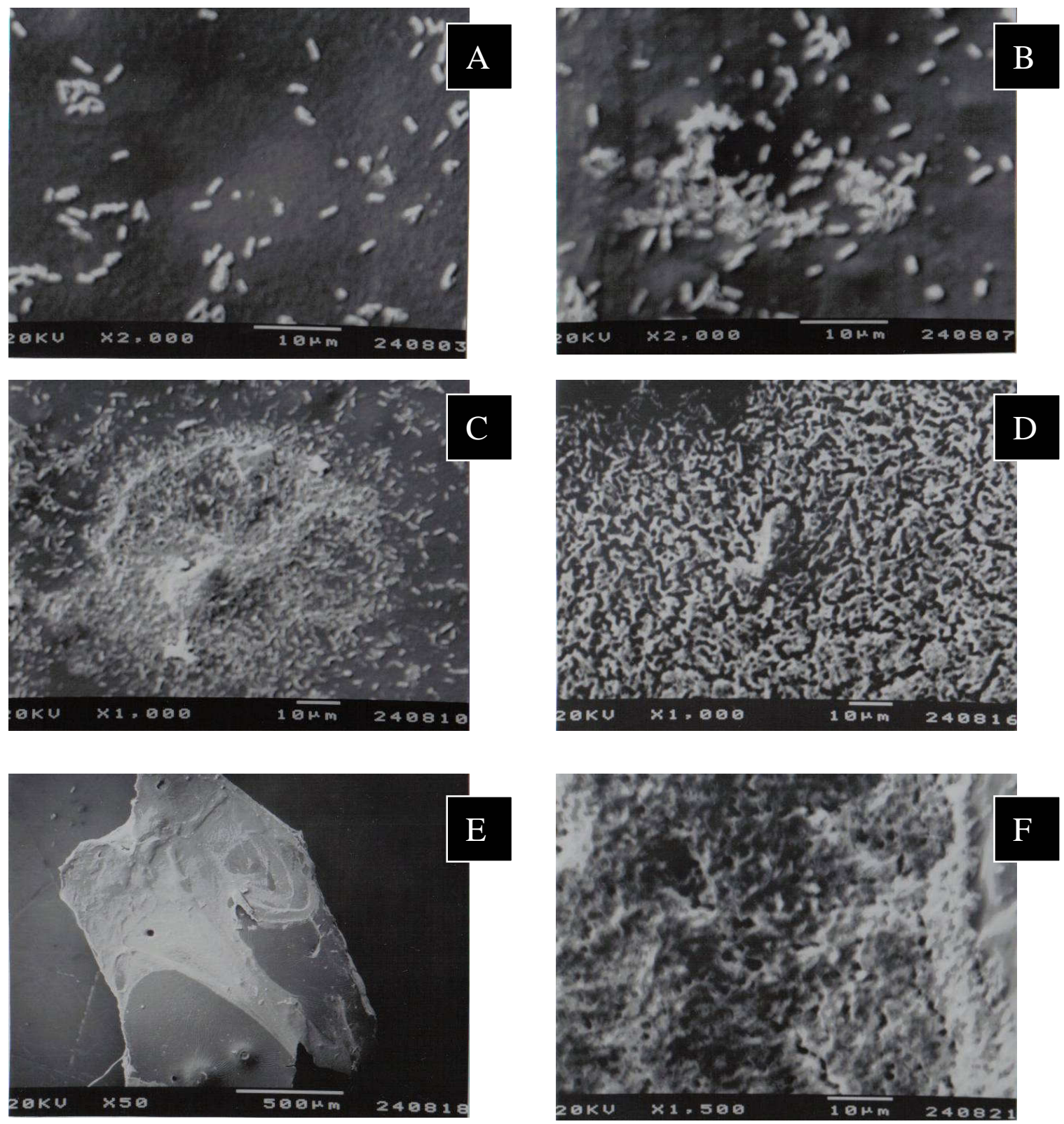

Figura 16 - Eletromicrografia de varredura da aderência e formação de biofilme de $P$. aeruginosa sobre a superfície do poliuretano em: (A) 1,5 horas de incubação (2000x), (B) 4 horas de incubação (2000x), (C) 24 horas de incubação (1000x), (D) 48 horas de incubação (1000x), (E) 72 horas de incubação (50x) e (F) 120 horas de incubação (1500x) (Microscópio eletrônico de varredura, JEOL-JSM, modelo T330A). 
A aderência da $P$. aeruginosa sobre a superfície do poliuretano foi observada em 1 hora e 30 minutos de incubação, mostrando uma aderência inicial, com início da multiplicação celular e produção de polissacarídeo extracelular. Em 4 horas de incubação observa-se um agrupamento celular e multiplicação celular. Em 24-48 horas de incubação observa-se um biofilme maduro, mostrando toda a superfície do poliuretano "coberta" pelo biofilme. Em 72 horas de incubação, observa-se a aderência e formação de biofilme, caracterizado pela mudança de cor da superfície do polímero. Em 120 horas de incubação observa-se um biofilme maduro, representado por uma massa amorfa, isto é, polissacarídeo extracelular envolvendo o biofilme.

5.3.1.4 - Superfície do poliuretano em contato com S. aureus, S. epidermidis e P. aeruginosa.

A Tabela 8 mostra o resultado qualitativo (MEV) da aderência das bactérias (S. aureus, S. epidermidis e P. aeruginosa) em contato com a superfície do poliuretano nos tempos de 1,5-120 horas. 
Tabela 8. Observação de biofilme usando MEV sobre a superfície do poliuretano.

\begin{tabular}{|c|c|c|c|c|}
\hline Poliuretano & $\begin{array}{l}\text { Tempo } \\
\text { (horas) }\end{array}$ & S. aureus & S. epidermidis & $P$. aeruginosa \\
\hline & 1,5 & Cocos & Cocos & Bacilos \\
\hline & 4 & $\begin{array}{l}\text { Cocos } \\
\text { agrupados com } \\
\text { produção de } \\
\text { PEC }\end{array}$ & $\begin{array}{c}\text { Cocos agrupados } \\
\text { com produção de } \\
\text { PEC }\end{array}$ & $\begin{array}{c}\text { Bacilos } \\
\text { agrupados com } \\
\text { produção de } \\
\text { PEC }\end{array}$ \\
\hline & 24 & $\begin{array}{l}\text { Agrupamentos } \\
\text { com produção } \\
\text { de PEC }\end{array}$ & $\begin{array}{l}\text { Agrupamentos } \\
\text { com produção de } \\
\text { PEC }\end{array}$ & $\begin{array}{l}\text { Agrupamentos } \\
\text { com produção } \\
\text { de PEC }\end{array}$ \\
\hline & 48 & $\begin{array}{c}\text { Agrupamentos } \\
\text { com produção } \\
\text { de PEC }\end{array}$ & $\begin{array}{l}\text { Agrupamentos } \\
\text { com produção de } \\
\text { PEC }\end{array}$ & $\begin{array}{c}\text { Agrupamentos } \\
\text { com produção } \\
\text { de PEC }\end{array}$ \\
\hline & 72 & $\begin{array}{l}\text { Agrupamentos } \\
\text { com produção } \\
\text { de PEC }\end{array}$ & $\begin{array}{l}\text { Agrupamentos } \\
\text { com produção de } \\
\text { PEC }\end{array}$ & $\begin{array}{l}\text { Agrupamentos } \\
\text { com produção } \\
\text { de PEC }\end{array}$ \\
\hline & 120 & $\begin{array}{c}\text { Massa amorfa } \\
\text { caracterizando } \\
\text { a produção } \\
\text { intensa de PEC }\end{array}$ & $\begin{array}{c}\text { Agrupamentos } \\
\text { com produção de } \\
\text { PEC e } \\
\text { comunicação } \\
\text { intercelular }\end{array}$ & $\begin{array}{c}\text { Massa amorfa } \\
\text { caracterizando a } \\
\text { produção } \\
\text { intensa de PEC }\end{array}$ \\
\hline
\end{tabular}

PEC - Polissacarídeo extracelular.

A caracterização do biofilme pode ser definida pela presença do polissacarídeo extracelular observado por meio de MEV e caracterizado por uma massa amorfa. 


\subsection{2 - Superfície do polipropileno.}

A Figura 17 mostra a superfície do corpo-de-prova de polipropileno antes da formação de biofilme (controle negativo).

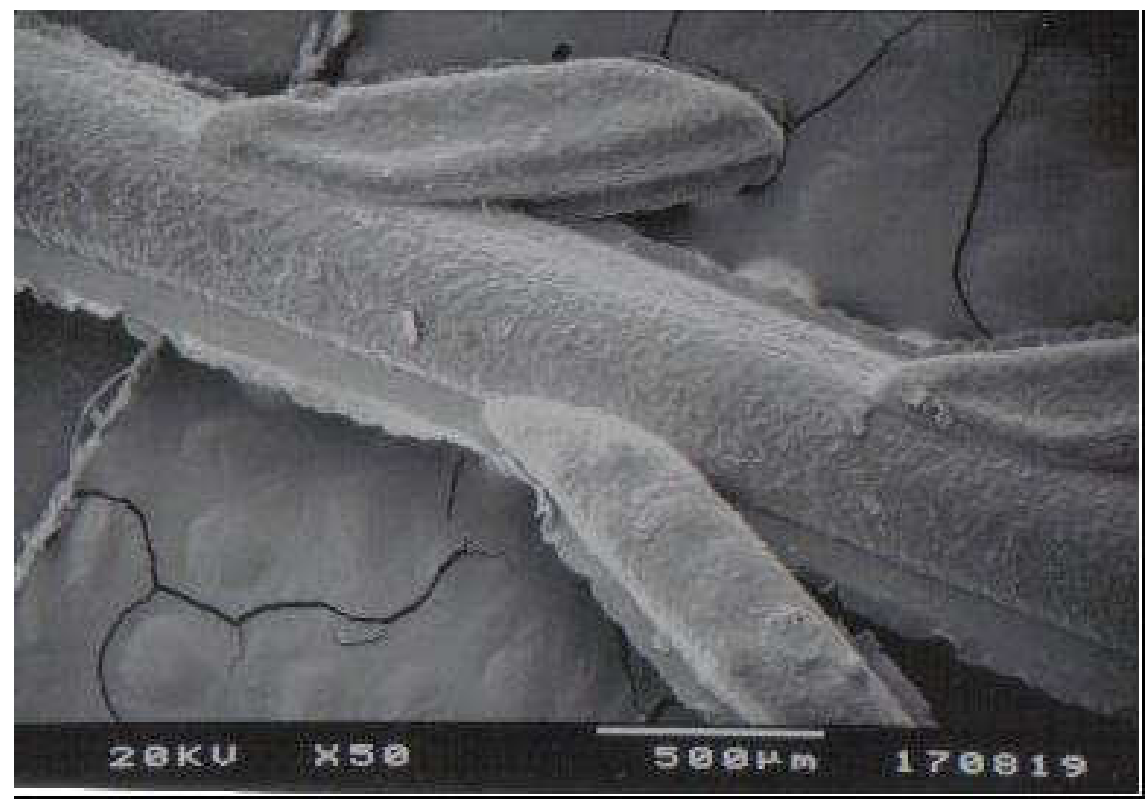

Figura 17 - Eletromicrografia de varredura (50x) do fio de polipropileno (controle negativo) (Microscópio eletrônico de varredura, JEOL-JSM, modelo T330A). 


\subsubsection{1 - Superfície do polipropileno em contato com S. aureus.}

Figura 18 eletromicrografia de varredura da superfície do corpo-de-prova de

polipropileno após a aderência e formação de biofilme de $S$. aureus, em 1,5 - 120 horas de incubação em caldo Mueller-Hinton.
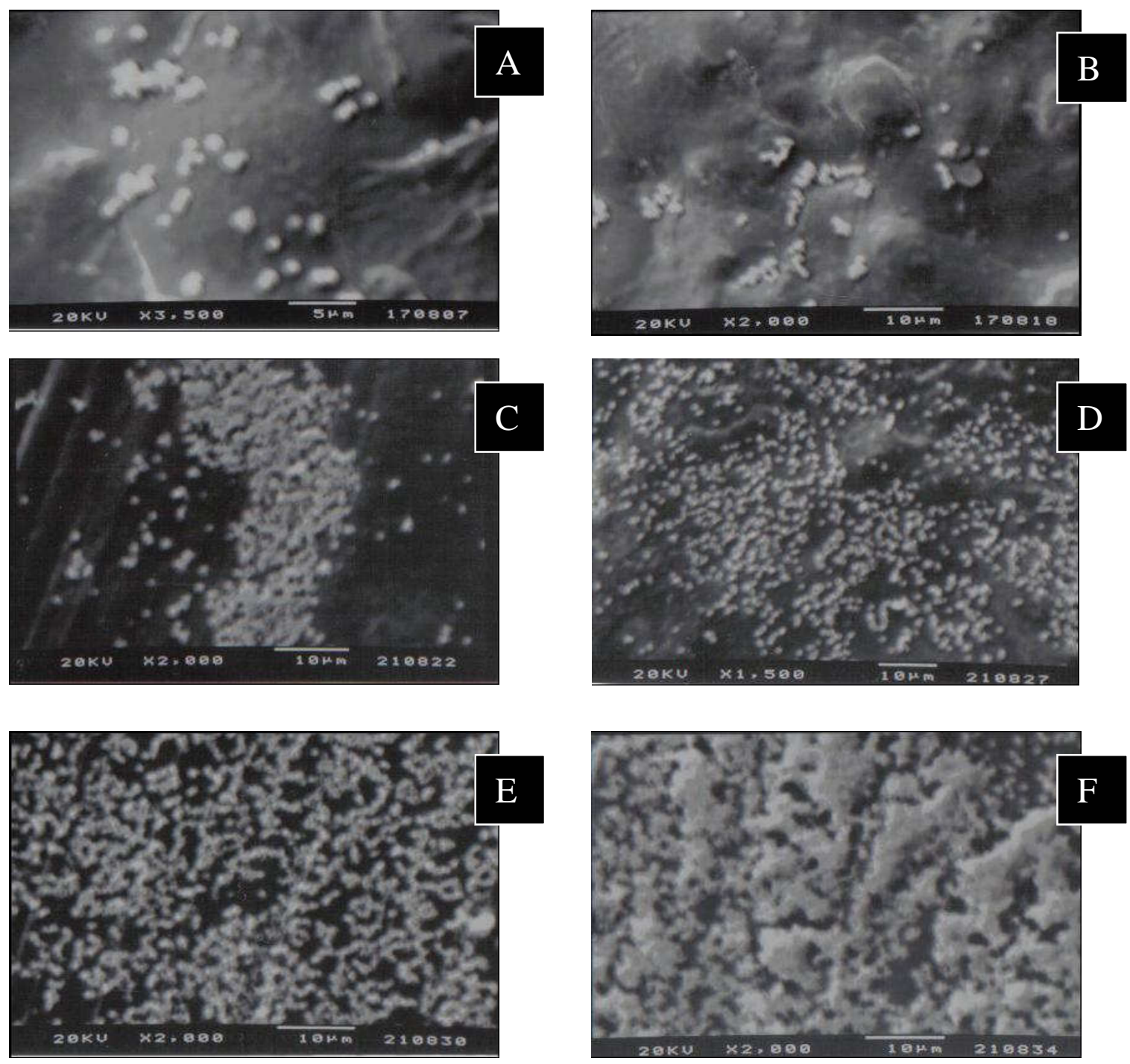

Figura 18 - Eletromicrografia de varredura da aderência e formação de biofilme de $S$. aureus sobre a superfície do polipropileno em: (A) 1,5 horas de incubação (3500x), (B) 4 horas de incubação (2000x), (C) 24 horas de incubação (2000x), (D) 48 horas de incubação (1500x), (E) 72 horas de incubação (2000x) e (F) 120 horas de incubação (2000x) (Microscópio eletrônico de varredura, JEOL-JSM, modelo T330A). 
A aderência do $S$. aureus sobre a superfície do polipropileno é observada em 1 hora e 30 minutos de incubação com inicio da divisão celular. Em 4-24 horas de incubação observa-se um agrupamento celular e multiplicação das células. Em 48-72 horas de incubação observa-se um crescimento e maturação do biofilme. Em 120 horas de incubação observa-se um biofilme maduro representado por uma massa amorfa, isto é, polissacarídeo extracelular envolvendo o biofilme. 


\subsubsection{2 - Superfície do polipropileno em contato com S. epidermidis.}

Figura 19 eletromicrografia de varredura da superfície do corpo-de-prova de polipropileno após a aderência e formação de biofilme de S. epidermidis, em 1,5 120 horas de incubação em caldo Mueller-Hinton.
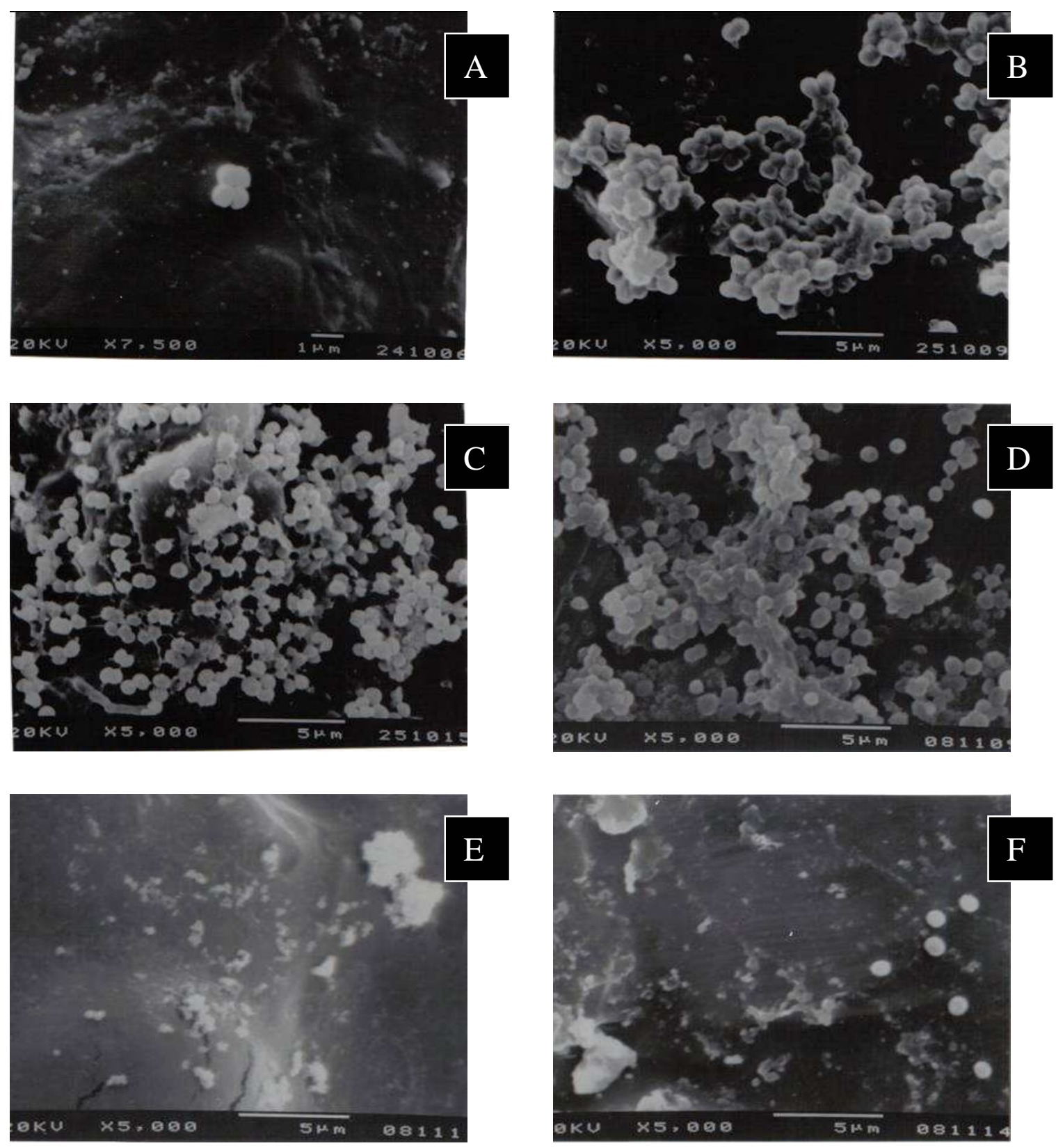

Figura 19 - Eletromicrografia de varredura da aderência e formação de biofilme de $S$. epidermidis sobre a superfície do polipropileno em: (A) 1,5 horas de incubação (7500x), (B) 4 horas de incubação (5000x), (C) 24 horas de incubação (5000x), (D) 48 horas de incubação (5000x), (E) 72 horas de incubação (5000x) e (F) 120 horas de incubação (5000x) (Microscópio eletrônico de varredura, JEOL-JSM, modelo T330A). 
A aderência do $S$. epidermidis sobre a superfície do polipropileno foi observada em 1 hora e 30 minutos de incubação, mostrando uma aderência inicial, com início da divisão binária da célula e produção de polissacarídeo extracelular. Em 4 horas de incubação observa-se agrupamento celular e crescimento do biofilme. Em 24-48 horas de incubação observa-se um biofilme maduro. Nos períodos de incubação de 72-120 horas observa-se uma diminuição de células aderidas sobre a superfície do polímero, caracterizando uma aderência inicial, supõe-se que em 48 horas de incubação houve uma liberação de células contidas no biofilme, devido ao acumulo excessivo de células. E, estas células aderidas sobre o polipropileno em 72-120 horas sejam células viáveis que irão formar um novo biofilme, porém, novos estudos deverão ser realizados para comprovar que são células viáveis, ou seja, células aderidas. 


\subsubsection{3 - Superfície do polipropileno em contato $P$. aeruginosa.}

Figura 20 eletromicrografia de varredura da superfície do corpo-de-prova de polipropileno após a aderência e formação de biofilme de $P$. aeruginosa, em 1,5 120 horas de incubação em caldo Mueller-Hinton.
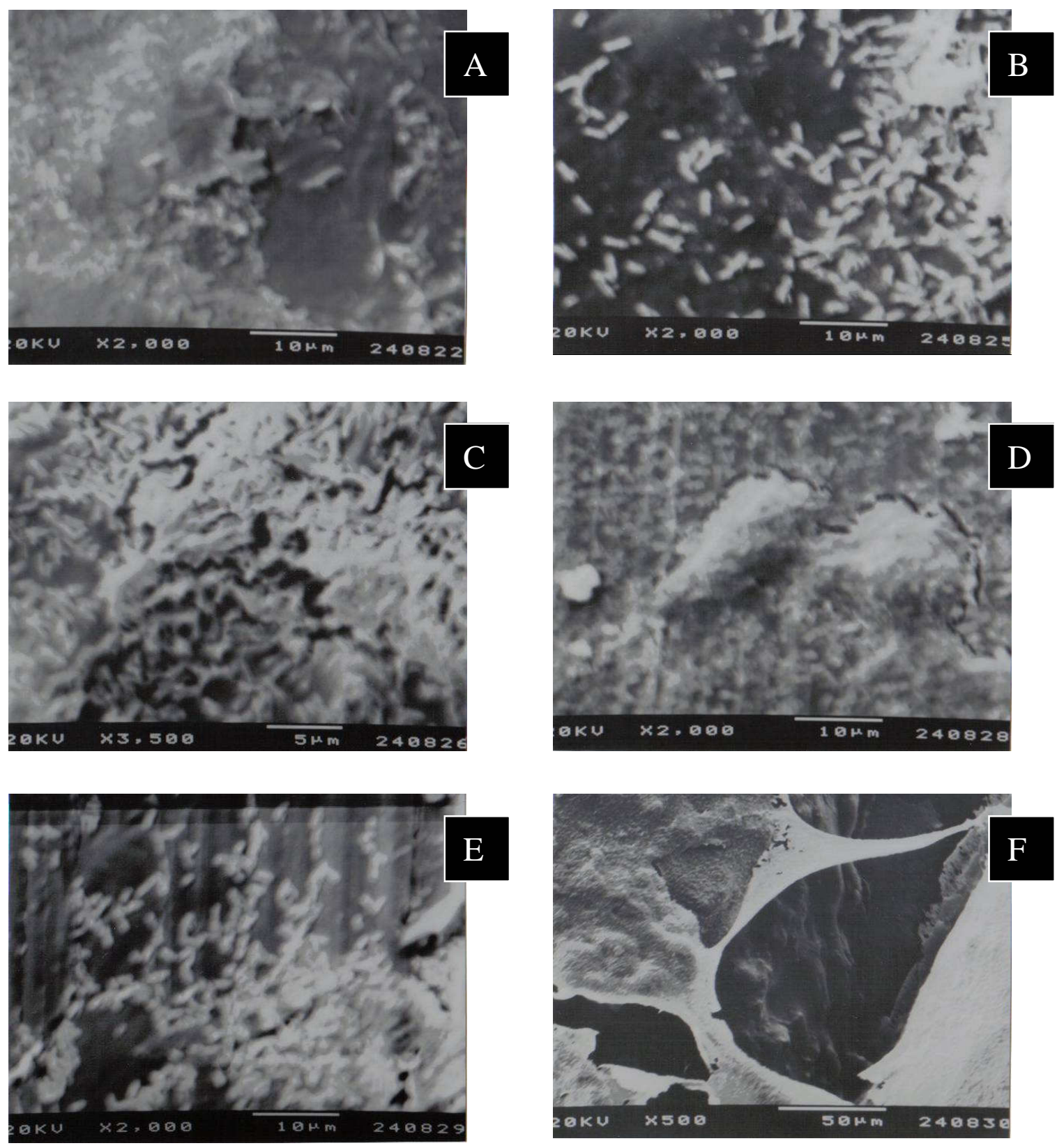

Figura 20 - Eletromicrografia de varredura da aderência e formação de biofilme de $P$. aeruginosa sobre a superfície do polipropileno em: (A) 1,5 horas de incubação (2000x), (B) 4 horas de incubação (2000x), (C) 24 horas de incubação (3500x), (D) 48 horas de incubação (2000x), (E) 72 horas de incubação (2000x) e (F) 120 horas de incubação (500x) (Microscópio eletrônico de varredura, JEOL-JSM, modelo T330A). 
A aderência da $P$. aeruginosa sobre a superfície do polipropileno foi observada em 1 hora e 30 minutos de incubação, com inicio da divisão celular, caracterizando uma aderência inicial. Em 4 horas de incubação observa-se uma multiplicação celular e crescimento do biofilme. Em 24-72 horas de incubação observa-se um biofilme maduro envolto por polissacarídeo extracelular, caracterizado por uma massa amorfa. Em 120 horas de incubação visualiza-se a presença do polissacarídeo extracelular, que envolve as células contidas no biofilme.

5.3.2.4 - Superfície do polipropileno em contato com S. aureus, S. epidermidis e $P$. aeruginosa.

A Tabela 9 mostra o resultado qualitativo (MEV) da aderência das bactérias (S. aureus, S. epidermidis e P. aeruginosa) em contato com a superfície do polipropileno nos tempos de 1,5-120 horas. 
Tabela 9. Observação de biofilme usando MEV sobre a superfície do polipropileno.

\begin{tabular}{|c|c|c|c|c|}
\hline Polipropileno & $\begin{array}{l}\text { Tempo } \\
\text { (horas) }\end{array}$ & S. aureus & S. epidermidis & P. aeruginosa \\
\hline & 1,5 & $\begin{array}{l}\text { Multiplicação } \\
\text { inicial dos cocos }\end{array}$ & $\begin{array}{l}\text { Cocos com início } \\
\text { da divisão binária }\end{array}$ & Bacilos \\
\hline & 4 & $\begin{array}{c}\text { Cocos } \\
\text { agrupados com } \\
\text { produção de } \\
\text { PEC }\end{array}$ & $\begin{array}{c}\text { Cocos agrupados } \\
\text { com produção de } \\
\text { PEC }\end{array}$ & $\begin{array}{l}\text { Bacilos } \\
\text { agrupados com } \\
\text { produção de } \\
\text { PEC }\end{array}$ \\
\hline & 24 & $\begin{array}{l}\text { Agrupamentos } \\
\text { com produção } \\
\text { de PEC }\end{array}$ & $\begin{array}{l}\text { Agrupamentos } \\
\text { com produção de } \\
\text { PEC }\end{array}$ & $\begin{array}{c}\text { Produção } \\
\text { intensa do PEC } \\
\text { caracterizado } \\
\text { por uma massa } \\
\text { amorfa }\end{array}$ \\
\hline & 48 & $\begin{array}{l}\text { Agrupamentos } \\
\text { com produção } \\
\text { de PEC }\end{array}$ & $\begin{array}{l}\text { Agrupamentos } \\
\text { com produção de } \\
\text { PEC }\end{array}$ & $\begin{array}{c}\text { Produção } \\
\text { intensa do PEC } \\
\text { caracterizado } \\
\text { por uma massa } \\
\text { amorfa }\end{array}$ \\
\hline & 72 & $\begin{array}{l}\text { Agrupamentos } \\
\text { com produção } \\
\text { de PEC }\end{array}$ & Cocos & $\begin{array}{l}\text { Agrupamentos } \\
\text { com produção } \\
\text { de PEC }\end{array}$ \\
\hline & 120 & $\begin{array}{c}\text { Massa amorfa } \\
\text { caracterizando } \\
\text { a produção } \\
\text { intensa de PEC }\end{array}$ & Cocos & $\begin{array}{c}\text { Produção de } \\
\text { PEC }\end{array}$ \\
\hline
\end{tabular}

PEC - Polissacarídeo extracelular.

A caracterização do biofilme pode ser definida pela presença do polissacarídeo extracelular observado por meio de MEV e caracterizado por uma massa amorfa. 


\subsection{3 - Superfície do poliuretano e polipropileno: Observação topográfica.}

\subsubsection{1 - Superfície do poliuretano.}

A Figura 21 mostra a superfície do corpo-de-prova do poliuretano.
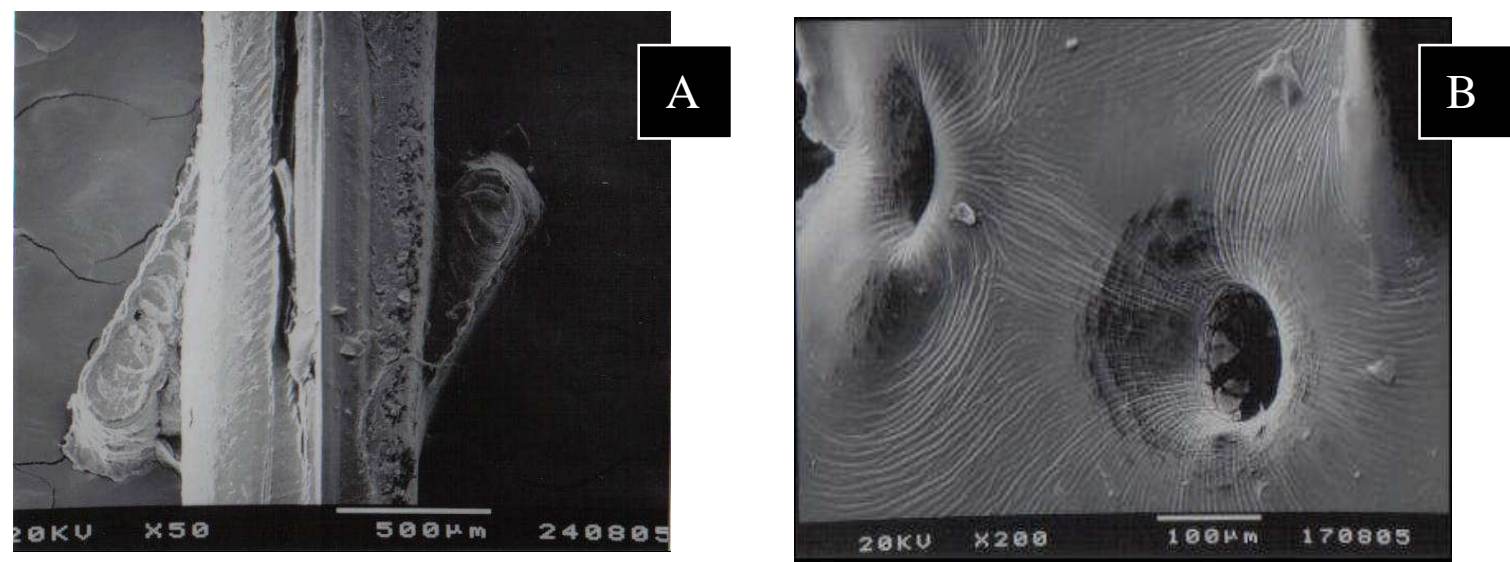

Figura 21 - Eletromicrografia de varredura da topografia da superfície do poliuretano: (A) 50x e (B) 2000x (Microscópio eletrônico de varredura, JEOLJSM, modelo T330A).

\subsubsection{2 - Superfície do polipropileno.}

A figura 22 mostra a superfície do corpo-de-prova do polipropileno.
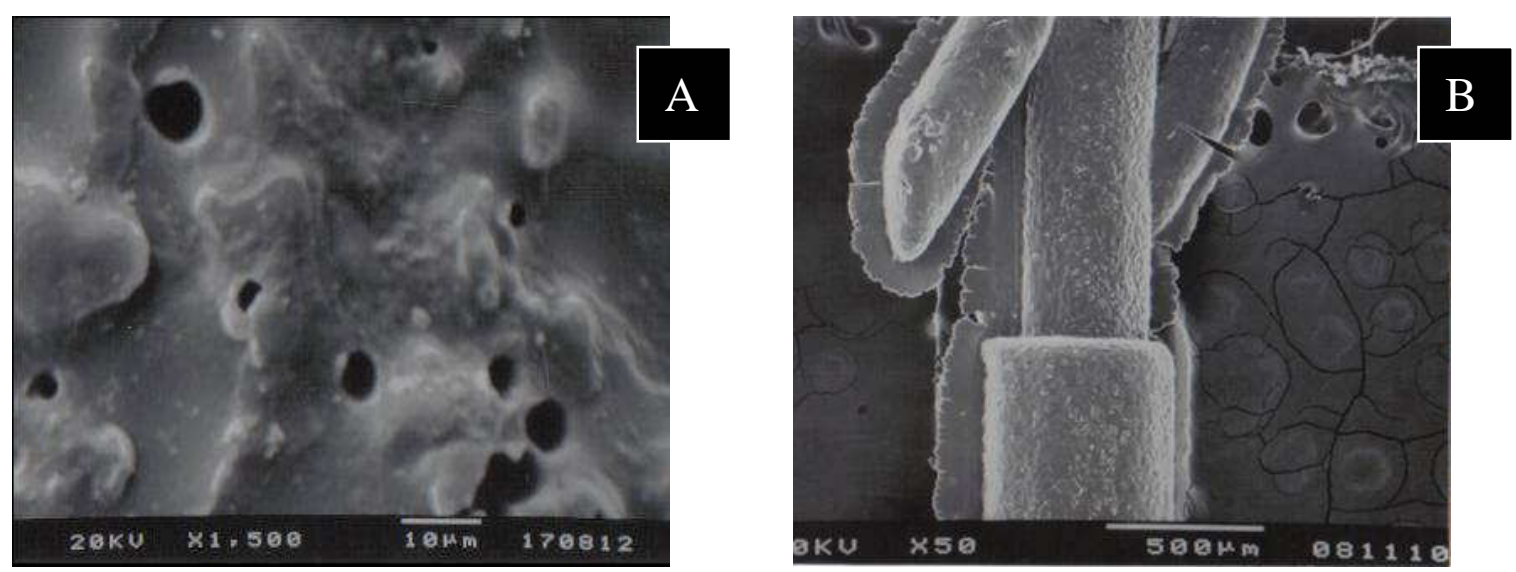

Figura 22 - Eletromicrografia de varredura da topografia da superfície do polipropileno: (A) 1500x e (B) 50x (Microscópio eletrônico de varredura, JEOL-JSM, modelo T330A). 
6 - DISCUSSÃO 
A presente pesquisa mostra a aderência de bactérias sobre fios de poliuretano desenvolvido a partir de fonte vegetal e de polipropileno. A colonização do polipropileno e do poliuretano foi comparada e observou-se que em ambas superfícies houve o crescimento e formação de biofilme. O presente estudo está de acordo com as observações de Fleming et al. (2000) os quais compararam a colonização do poliuretano termoplástico e vários poliuretanos funcionalizados, após imersão dos corpos-de-prova em meio de cultura em caldo, observaram que a bactéria sobreviveu e multiplicou formando biofilme.

Os microrganismos são capazes de aderir a diferentes tipos de superfícies (BELLÓN et al., 2001) e formar biofilme, o qual consiste de microcolônias heterogêneas altamente organizadas e funcionais (COSTERTON et al., 1999). A formação do biofilme também permite que a bactéria fique latente sobre a superfície do material até que o meio ambiente favoreça a multiplicação, ou seja, até que diminua a função imune do hospedeiro e ocorra infecção relacionada ao biomaterial, isto poderia explicar o surgimento tardio da infecção, mesmo após muitos anos da implantação (TAYLOR; DWYER, 1999). Também, Marrie et al. (1983), Schartz et al. (1991) e Poisset et al. (1991), relataram que a aderência bacteriana é um fenômeno importante para o início do processo infeccioso ao redor de um implante.

O presente trabalho confirmou in vitro a existência de biofilme sobre a superfície de fios de poliuretano e polipropileno. O fio de polipropileno foi usado em 1999 por Jones; Jurkovick (1999) para reparar as falhas da parede abdominal infeccionada. Os trabalhos de Law; Ellis (1991) demonstraram a integração dos tecidos na presença de contaminação bacteriana sem haver a alteração da resistência mecânica do implante. Em relação ao fio de poliuretano é um dos polímeros mais usados na confecção de próteses médicas e é um dos polímeros 
mais estudados em relação a aderência bacteriana, quando comparado com outros polímeros (LOPEZ-LOPEZ et al., 1991; MARTINEZ-MARTINEZ et al., 1991). Mas, o poliuretano, estudado na presente pesquisa, é o de origem vegetal e para esse os estudos de aderência bacteriana são inéditos.

O presente estudo mostra (Tabelas 1,3 e 5), o número de unidades formadoras de colônia, após 1 hora e 30 minutos de contato da superfície do poliuretano com bactérias Gram-positivas: $S$. aureus e $S$. epidermidis, bem como de Gram-negativa: P. aeruginosa. Para $S$. aureus e $S$. epidermidis havia cerca de 10.000 UFC (unidades formadoras de colônia) e para o polipropileno 20.000 UFC, estes dados são semelhantes aos encontrados por Fleming et al. (2000) após uma hora de contato da superfície do poliuretano elastomero com $S$. aureus havia cerca de 30.000 UFC. E diferentes dos encontrados por Pinna et al. (2000) relataram que após 1 hora e 30 minutos de contato com S. epidermidis havia 1.100 UFC sobre a superfície do polimetilmetacrilato (PMMA).

Após 4 horas de contato do $S$. aureus e $S$. epidermidis com poliuretano, houve um aumento de 10 vezes, no número de células viáveis dos microrganismos, sugerindo a multiplicação das células (Tabelas 1 e 3 ). No entanto, as unidades formadoras de colônia de $S$. aureus, recuperadas após 24 horas de contato com poliuretano foram 300.000 UFC. Dados concordantes com Russel et al. (1987) e Patel et al. (2007).

Em relação ao fio de polipropileno as células viáveis de $S$. aureus recuperadas após 1 hora e 30 minutos foram em torno de 20.000 UFC e $S$. epidermidis 10.000 UFC. Os dados da presente pesquisa em relação ao fio de polipropileno, também são concordantes com os de Fleming et al. (2000) e diferentes dos encontrados por Pinna et al. (2000). 
Na presente pesquisa a cinética de aderência dos isolados de $S$. aureus e $S$. epidermidis aos fios de poliuretano e polipropileno (Figs 9 e 10) mostra que ocorreu rapidamente (1h e 30 minutos), aumentando após 4 horas e alcançando o pico máximo em 48 horas de incubação. A aderência de cada espécie de estafilococos ao poliuretano e ao polipropileno foi semelhante. A análise estatística mostrou que não houve diferença estatisticamente significante $(p<0.05)$.

No entanto, em 120 horas de contato com poliuretano, as unidades formadoras de colônia de $S$. aureus aumentaram. E as unidades formadoras de colônia de S. epidermidis diminuíram após 72 e 120 horas.

Em relação a $P$. aeruginosa o contato de 1 hora e 30 minutos com a superfície do poliuretano mostrou cerca de 100.000 UFC e o contato com polipropileno cerca de 600.000 UFC (Tabela 5). O pico máximo de aderência foi alcançado em 24 horas, aumentando o número de unidades formadoras de colônias em 72 e 120 horas. A análise estatística mostrou que as médias, de aderência da $P$. aeruginosa sobre a superfície de polipropileno e de poliuretano, não são significantemente diferentes $(p<0.05)$, ou seja, ambos os fios permitem a aderência e formação de biofilme, sugerindo que são polímeros suscetíveis à infecção. Hofling et al. (2007) relataram um caso de infecção com Mycobacterium fortuitum em um procedimento de lifting facial após inserção do de fio de polipropileno. Ji; Zhang (2008) relataram que a infecção sobre implantes médicos poliméricos é freqüentemente causada por aderência bacteriana e formação de biofilme.

Ao comparar-se o número de unidades formadoras de colônias de $S$. aureus e $S$. epidermidis e $P$. aeruginosa sobre poliuretano e polipropileno, a análise estatística mostrou que as médias aritméticas não são significantemente diferentes $(p<0.05)$. No entanto, ao comparar-se o número de unidades formadoras de colônia 
de $S$. epidermidis e $P$. aeruginosa, sobre a superfície do polipropileno e poliuretano, a análise estatística mostrou que as médias são significantemente diferentes $(p<0.05)$

Ao comparar-se o número de unidades formadoras de colônia de $S$. aureus e $P$. aeruginosa, sobre a superfície do poliuretano observou-se que as médias são significantemente diferentes $(\mathrm{p}<0.05)$. No entanto, sobre a superfície do polipropileno não houve diferença estatisticamente significante entre as unidades formadoras de colônia de $S$. aureus e $P$. aeruginosa.

Em resumo a bactéria Gram-negativa ( $P$. aeruginosa) aderiu mais aos fios de poliuretano e polipropileno do que as bactérias Gram positivas ( $S$. aureus e $S$. epidermidis). Dados concordantes com Locatelli et al. (2004).

Na presente pesquisa foi usado o microscópio eletrônico de varredura para observar a formação de biofilme de $S$. aureus, $S$. epidermidis e $P$. aeruginosa sobre a superfície dos fios poliuretano (Fig. 14-16 e Tabela 8) e polipropileno (Fig. 18-20 e Tabela 9). Uma das características do biofilme é a presença de polissacarídeo extracelular, uma substância polimérica que circunda as células bacterianas. Essa substância pode ser observada por microscópio eletrônico de varredura e aparece como fios que conectam as células a superfície e entre si ou material amorfo sobre a superfície. Os dados são concordantes com Donlan (2001), Donlan; Costerton (2002), Storti et al. (2005).

No presente estudo, biofilmes bacterianos (S. aureus, $S$. epidermidis e $P$. aeruginosa) foram observados sobre a superfície de fios de poliuretano e de polipropileno por meio de microscopia eletrônica de varredura. Os resultados são concordantes com os estudos de Nagaoka; Kawakami (1995) que avaliaram a aderência e formação de biofilme do $S$. aureus e $E$. coli por meio de microscopia 
eletrônica de varredura, sobre superfícies de polímeros (PVC e polietileno), observaram a aderência bacteriana e formação de biofilme em ambos os polímeros.

Outro aspecto relevante neste estudo foi a avaliação topográfica da superfície dos polímeros (poliuretano e polipropileno) por meio da microscopia eletrônica de varredura, em que estavam evidenciados defeitos e imperfeições, essas irregularidades podem reter microrganismos. Esses dados são concordantes com Peter et al. (1982) observaram a formação de biofilme de S. epidermidis sobre a superfície do cateter de poliuretano por meio de microscopia eletrônica de varredura e, observaram irregularidades sobre a superfície do cateter. S. epidermidis aderiu preferencialmente a essas irregularidades. Também, Gabriel et al. (1998); Garcia et al. (2000); Pinna et al. (2000) e Pinna et al. (2001) estudaram a aderência do S. epidermidis em diferentes lentes intra-oculares, polimetilmetacrilato (PMMA), silicone, hidrogel e acrilico. Por meio de MEV, observaram irregularidades sobre a superfície das lentes, e $S$. epidermidis aderiu-se preferencialmente a essas irregularidades. Marrie et al. (1981) mostraram a aderência do $S$. aureus e $S$. epidermidis sobre superfícies de cateteres intravenosos por meio de microscopia eletrônica de varredura. Observaram que as superfícies dos cateteres eram imperfeitas e irregulares. $S$. aureus e $S$. epidermidis aderiram-se preferencialmente nas áreas irregulares do cateter.

Assim, entende-se que o acabamento superficial dos implantes poliméricos deva ser uniforme e não possuir irregularidades maiores que o tamanho dos microrganismos, que provavelmente facilitam a aderência dos microrganismos (BELANGERO et al., 2006). Qiu et al. (2007) sugerem modificação da superfície de biomateriais para reduzir as infecções sobre os implantes.

A interação entre bactéria e biomaterial continua sendo assunto para estudo 
detalhado, porque a infecção representa hoje um problema sério na cirurgia de implantes. As irregularidades ou porosidade parecem facilitar a aderência e fornecer uma proteção física para o microrganismo contra antibióticos e resposta imune do hospedeiro.

Pretende-se continuar estudando a interação de microrganismos com superfícies de biomateriais, aplicando-se outras técnicas e microscopias mais avançadas. 
7-CONCLUSÕES 
1. Da avaliação quantitativa da viabilidade das células ( $S$. aureus, $S$. epidermidis e $P$. aeruginosa) em biofilme por métodos de cultura, revelou unidades formadoras de colônia (UFC/ml) em 1 hora e 30 minutos a 120 horas de incubação.

2. Da avaliação qualitativa de aderência bacteriana e formação de biofilme sobre a superfície dos polímeros (poliuretano e polipropileno) por observação microscópica (microscópio eletrônico de varredura) revelou, formação de biofilme por $S$. aureus, $S$. epidermidis e $P$. aeruginosa em ambos os polímeros analisados.

3. Da avaliação topográfica dos polímeros por meio de microscopia eletrônica de varredura, mostrou que as superfícies dos polímeros são irregulares, apresentando imperfeições e superfície irregular. 
ADAMAYAN, A.A. Clinical aspects of facial skin reinforcement with special (gold) surgical filaments. Ann. Plas. Recons. Surg., 3, 18-22, 1998.

ACHESION, J.F.; LYONS, C.J. Ocular morbidity due to monofilament nylon corneal sutures. Eye., v.5, p.106-112, 1991.

ARA, C.A. Fijacion cervical con polímero vegetal. Rev. Neurocir., v.2 (supl.3), p.103107, 1999.

ARCIOLA, C.R.; ALVI, F.I.; CAMPOCCIA, D.; MONTANARO, L. Implant infection and implant resistant materials: a mini review. Int. J. Artif. Organs., v.28 (supl.11), p.1119-25, 2005.

AKIYAMA, H.; TORIGOE, R.; ARATA, J. Interaction of Staphylococcus aureus cells and silk threads in mouse skin. J. Dermatol. Sci., p.247-57, 1993.

ASHBY, M.; JONES, D. Polymer. Eng. Materials, ed.2, p.191-195, 1996.

AOKI, E.O.; PIZZOLITTO, A.C.; GARCIA, L.B.; PIZZOLITTO, E.L. Staphylococcus aureus biofilms on central venous haemodialysis catheters. J. Microbiol., v.36, p.342-346, 2005.

AZEVEDO, P.E.S; GUEIROS, G.V.T.; FREIRE, V.G.; CHIERICE, G.O. Uso da membrana de polímero de mamona em regeneração óssea guiada em defeitos ao redor de implantes osseointegrado. Rev. Bras. Implant. , v.3, n.6, p. 8-12, 1997.

BAILLIF, S.; ECOCHARD, R.; CASOLI, E.; FRENEY, J.; BURILLON, C.; KODJIKIAN, L. Adherence and Kinects of biofilm formation on Staphylococcus epidermidis to different types of intraocular lenses under dynamic flow conditions. J. Cataract. Refact. Surg., v.34 (supl.1), p.153-8, 2008.

BELANGERO, V.M.; GONÇALVES, R.C.; LUTAIF, A.C.G.B.; PRATES, L.C.; RIGATTO, S.Z.P.; MIRANDA, M.L. Evaluation of Peritoneal Dialysis Catheters Using Scn Electron Microscopy. J. Bras. Nefrol., v.4, 2006.

BELLÓN, J.M.; HONDUVILLA, N.G.; JURADO, F.; CARRANZA, A.G.; BUJÁN, J. In vitro interaction of bacteria with polypropylene/ e PTFE protheses. Biomaterials, v.22, p.2021-2024, 2001.

BERNARDI, A.C.A.; PIZZOLITTO, E.L.; PIZZOLITTO, A.C. Detecção da produção de slime por estafilococos coagulase-negativa isolados de cateter venoso central. Rev. Cienc. Farm., v.28, n.1, p.57-66, 2007.

BURET, A.; WARD, K.H.; COSTERTON, J.W. An in vivo model to sutdy the pathobiology of infectious biofilms on biomaterial surfaces. J. Biomed., v.25, n.7, p.865-874, 2004.

CANGEMI, J.M.; CLARO NETO, S.; CHIERICE, G.O.; SANTOS, A.M. Study of the biodegradation of a polymer derived from castor oil by scanning electron microscopy, thermogravimetry and infrared spectroscopy. Polímeros, v.16, n.2, 2006. 
CAVALCA, D. Uso do composto ósteo-ricinus em reconstrução de perdas ósseas em ortopedia. J. Cienc. Tecnol. Biomat., v.1, 1998.

CERI, H.; OLSON, D.; MORCK, D.; STOREY, R.; READ, A.; BURET and B. OLSON. The MBEC assay system: Multiple equivalent biofilms for antibiotic and biocide susceptibility testing. Growth in Biofilms, v.337, p.337-385, 2001.

CHAMBERLAIN, A.H.L. The role os adsorbed layers in bacterial adhesion. Biofilms. Science and Technol., p.59-67, 1992.

CHEVALLAY, B.; HERBAGE, D. Collagen-based biomaterials as 3D scaffold for cell cultures: applications for tissue engineering and gene therapy. J. Medical. end Biological. Engineering and Computing., v.38, n.2, 2000.

CHOONG, S.; WHITFIELD, H. Biofilms and their role in infections in urology. Bju. International., v.86, p.935-941, 2000.

COSTA, E.; PEREIRA, L.T.P.; ANDRADE, A.V.C.; BORGES, C.P.F.; MARQUES, M.B.; CRUZ, A.C.C.; SANTOS, F.A.; SILVA, J.C.Z. Sinterização de biovidros na forma de partículas e do tipo espuma. Rev. Biotec. Ciênc. Desenv., 2003.

COSterton, J.W.; GEESEY, G.G.; CHENG, K.J. How bacteria stick . Sci. Am., v.238 (supl.11), p.86-95, 1978.

COSTERTON, J.W.; MARRIE, T.J.; CHENG, K.J. Phenomena of bacterial adhesion. In: Bacterial Adhesion, p.3-43, 1985.

COSTERTON, J.W.; STEWART, P.S.; GREEBERG, E.P. Bacterial Biofilms: a commo cause of persistent infetions. Science, v.284, p.1318-22, 1999.

COSTERTON, J.W.; MONTANARO, L.; ARCIOLA, C.R. Biofilm in implant infections: its production and regulation. J. Artif. Organs., v.28 (supl.11), p.1062-8, 2005.

DONLAN, R.M. Biofilms and device-associated infections. Emerg. Infect. Dis., v.7, p.277-281, 2001.

DONLAN, R.M.; COSTERTON, J.W. Biofilms: Survival Mechanisms of Clinically Relevant Microorganisms. Rev. Clin. Microbiol., v.15, n.2, 2002.

DONTOS, A.C. Fio Lifting Biológico (fio serrilhado de poliuretana do óleo de mamona). Avaliação de sua biocompatibilidade e eficácia no rejuvenescimento facial. Dissertação (Mestrado no Programa na Interunidades em Bioengenharia)Universidade de São Paulo, São Carlos, 2006.

ELASRI, M.O.; MILLER, R.V. Study of the response of a biofilm bacterial community to UV radiation. Applied and Envirommental Microbiol., v.65 (supl.5), p.20252031, 1999.

FLEMMING, R.G.; CAPELLI, C.C.; COOPER, S.L.; PROCTOR, R.A. Bacterial colonization of functinalized polyurethanes. Biomat., v.21, p.273-281, 2000. 
FRED, G.; FEDOK, F.G. The aging face. Fac. Plast. Surg., v.12 (supl.12), p.107$115,1996$.

FUENTEFRIA,N.; BRITO,J.H.M.; WEISMANN,R. Avaliação histológica da reação tecidual frente a implante de poliuretana vegetal, na tíbia de rato. Odonto. Ciênc., v.13, n.26, p.29-49, 1998.

GABRIEL, M.M.; AHEARN, D.G.; CHAN, K.Y.; PATEL, A.S. In vitro adherence os Pseudomonas aeruginosa to four intraocular lenses. J. Cataract. Refrauct. Surg., v.24 (supl.1), p.124-9, 1998.

GARCÍA, M.C.S.; ARIAS, A.P.; FRESNADILLO, M.J.M.; MATILLA, A.R. In vitro adhesion os Staphylococcus epidermidis to intraocular lenses. J. Cataract. Refrauct. Surg., v.26 (supl.11), p.1673-9, 2000.

GARCIA-URENA, M.A.; VEGA, R.V.; DIAZ, G.A.; BAEZ, P.J.M.; MARIN, G, L.M.; CARNERO, H.F.J.; VELASCO, G.M.A. Differences in polypropylene shrinkage depending on mesh position in an experimental study. J. Surg., v.193, p.538-42, 2007.

GIL, S.M.; POLITO, W.; JUNIOR, C.P.C.; GIL, B.Z.; CENTURION, L.M.; RODRIGUES, L.F.D. Polypropylene mesh: study of the effect of sterilization in the structure of a mesh fragment reused in hernia surgery. Acta Scient. Veterin., v.32, n.4, 2005.

GOODMAN, A.E.; MARSHALL, K.C. Genetic responses of bacteria at surface. Microbial Biofilms., p.81-95, 1995.

GOLDENBERG, A.; MATONE, J.; MARCONDES, W.; FOCCHI, G. Effects of the polypropylene mesh in the testicle ductus deferens of dogs. Acta Cir. Bras., v.16, n. 4, 2001.

GOLDMAN, D.A.; PIER, G.B. Pathogenesis of infection related to intravascular catheterization. Rev. Clin. Microbiol., v.6, p.176-192, 1993.

GRISTINA, A.G. Biomaterial centered infection: microbial adhesion versus tissue integration. Science, v.237, p.1588-95, 1987.

GUS, P.L.; MELAMED, J.; BARTH, A.; SUDHAUS, B.D.; QUINTO, G.; MATOS, G.H.; BAYER, M.C. In vitro adherence of Staphylococcus epidermidis and Pseudomonas alcaligenes to intraocular lenses. Arq. Bras. Oftalmol., v.69 (supl.3), p.327-31, 2006.

HEAVEN, C.J.; BOASE, D.L. Suppurative Keratitis with endophthalmitis due to biodegraded full thickness monofilament nylon corneal sutures. J. Implat. Refract. Surg., v.5, p.164-168, 1993.

HOFLING, C.C.; PANUNTO, A.C.; BENSI, E.P.A.; GONÇALVES, S.A.; RAMOS, M.C.; RIENZO, A.A.R. Infection of polypropylene threads for face-lifting with Mycobacterium fortuitum. Dermatol. Surg., v.33 (supl.4), p.492-495, 2007. 
IGNÁCIO,H.; MAZZER,N.; BARBIERI, C.H.; CHIERICE,G.O. Utilização da poliuretana de mamona nas formas compacta e porosa no preenchimento de falha óssea: estudo experimental em cães. Rev. Bras. Ortop., v.37, n.5, p.187-194, 2002.

JI, J.; ZHANG, W. Bacterial behaviors on polymer surface with organic and inorganic antimicrobial compounds. J. Biomed. Materials Res., 2008.

JONES, J.W.; JURKOVICH, G.P. Polypropylene mesh closure of infected abdominal wounds. Am. Surg., v.55, p.73-6, 1999.

JOYANES, P.; PASCUAL, A.; MARTÍNEZ-MARTÍNEZ, L.; HEVIA, A.; PEREA, E.J. In Vitro Adherence of Enterococcus faecalis and Enterococcus faecium to Urinary Catheters. J. Microbiol. Infects Dis., v.19, p.124-127, 2000.

KATSIKOGIANNI, M.; SPILIOPOULOU, I.; DOWLING, D.P.; MISSIRLIS, Y,F. Adhesion of slime producing Staphylococcus epidermidis strains to PVC and diamont-like carbon/silver/fluorinated coatings. Mater. Sci. Mater. Med., v.8, 2006.

KHARDORI, N.; YASSIEN, M.L. Biofilms in device-related infections. J. Microbiol., v.15, p.141-417, 1995.

KUMON, H.K; TOMOCHIKA, K.; MATUNAGA, T.; OGAWA M.; OHMORI, H. A sandwich cup method for the penetration assay of antimicrobial agents through Pseudomonas aeruginosa expolysaccharides. Microbiol. Immunol., v.38, p.615-619, 1994.

LAW, N.W.; ELLIS, H. A comparison of polypropylene mesh and expanded polytetrafluorrthylene patch for the repair of contamined abdominal wall defects. An experimental study Surgery., v.109, p.652-9, 1991.

LAWRENCE, J.R.; KORBER, D.R.; HOYLE, B.D.; COSTERTON, J.W.; CALDWELL, D.E. Optical sectioning of microbial biofilms. J. Bacteriol., v.173, p.6558-6567, 1991.

LEEGRAND, J.J.; BARTOLLETTI, C.; PINTO, R. Manual Práctico de Medicina Estética, 3aㅗ edição, capítulo Argentino de Medicina Estética, 1998.

LEONEL, E.C.F.; PORCIUNCULA, H.F.; SOBRINHO, J.A.; RAMALHO, L.T.O.; MANGILLI, P.D.; RAPOPORT, A. The action of the castor bean polymer during the bone neoformation. Acta. Cir. Bras., v.19, n.4, 2004.

LI, X.; KING, M.; MACDONALD, P. Comparative study of knot performance and ease of manipulation of monofilament and braided sutures for arthroscopic applications. Rev. Traumatol. Arthrosc., v.12, p.448-52, 2004.

LOCATELLI, C.I.; ENGLERT, G.E.; KWITKO, S.; SIMONETTI, A.B. In vitro bacterial adherence to silicone and polymetylmetacrylate intraocular lenses. Arq. Bras. Oftalmol., v.67, n.2, 2004.

LOPEZ-LOPEZ, G.; PASCUAL, A.; PEREA, E.J. Effect of plastic catheter material on bacterial adherence and viability. J. Med. Microbiol., v.34, p.349-53, 1991. 
MACKINTOSH, E.E.; PATEL, J.D.; MARCHANT, R.E.; ANDERSON, J.A. Effects of biomaterial surface chemistry on the adhesion and biofilm formation of Staphylococcus epidermidis in vitro. Inter. Science, v.78, p.836-842, 2006.

MARRIE, T.J.; COSTERTON, J.W. Prolonged survival of Serratia marcescens in chlorhexidine. Appl. Environ. Microbiol., v.42, p.1093-1102, 1981.

MARRIE, T.J.; NOBLE, M.A.; COSTERTON, J.W. Examination of the morphology of bacteria adhering to peritoneal dialysis catheters by scanning and transmission electron microscopy. J. Clin. Microbiol., v.18, p.1388-98, 1983.

MARSHALL, K.C.; STOUT, R.; MITCHELL, R. Mechanisms of the initial events in the sorption of marine bacteria to surface. J. Gen. Microbiol., v.68, p.337-48, 1971.

MARTINEZ-MARTINEZ, L.; PASCUAL, A.; PEREA, E.J. Kinects of adherence of mucoid and non-mucoid Pseudomonas aeruginosa to plastic catheters. J. Med. Microbiol., v.34, p.7-12, 1991.

MÉLEGA, J.M.; ZANINI, S.A.; PSILAKIS, J.M. Cirurgia Plástica Estética e Reparadora. Medsi, ed.2, 1992.

MELO, R.S.; GOLDENBERG, A.; GOLDENBERG, S.; LEAL, A.T. Effects of polypropylene prosthesis placed by inguinotomy in the peritonial space, in dogs: evaluation laparoscopic and microscopic. Acta. Cir. Bras., v.18, n.4, 2003.

MITTELMAN, M.W. Adhesion to biomaterials. Wiley-Liss, p.89-127, 1996.

MIYANO, N.; OIE, S.; KAMIYA, A. Efficacy of disinfectantes and hot water against biofilm cells of Burkolderia cepacia. Biol. Pharm. Bull., v.26, p.671-674, 2003.

MOHAMED, E.O.; MILLER, R.O. Study of the Response of a Biofilm Bacterial Community to UV Radiation. Microbiol., v.65, p.2025-2031, 1999.

MONTIVILLE, R.; SCHAFFNER, D.W. Inoculum size influenzes bacterial cross contamination between surfaces. Appl. Envrion. Microbiol., v.69, p.7188-7193, 2003.

NAGAOKA, S.; KAWAKAMI, $\mathrm{H}$. Inhibition of bacterial adhesion and biofilm formation by a heparinized hydrophilic polymer. Asaio J., v.41 (supl.3), 1995.

NIVENS, D.E.; OHMAN, D.E.; WILLIAMS, J.; FRANKLIN, M.J. Role of alginate and its $\mathrm{O}$ acetylation in formation of Pseudomonas aeruginosa microcolonies and biofilms. J. Bacteriol., v.183, p.1047-57, 2001.

ODO MEY.; CHICHIERCHIO, A.L. Prática em Cosmiatria e Medicina Estética Procedimentos Cirúrgicos de Pequeno Porte, Tecnopress, 1999.

OLSON, M.E.; GARVIN, K.L.; FEY, P.D.; RUPP, M.E. Adherence of Staphylococcus epidermidis to biomaterials is augmented by PIA. Clin. Orthop. Relat. Res., v.451, p.21-4, 2006. 
PADILHA, A.F. Materiais de Engenharia: Microestruturas e propriedades. Hemus, 1994.

PAN, J.C.H.; LAU, B.H.; FAM, H.B. Evaluation of biofilm formation on nylon sutures removed from clinically noninfected eyes after cataract surgery. J. Cataract Refractive Surgery., v.30 (supl.30), p.1972-6, 2004.

PATEL, J.D.; ELBERT, M.; WARD, R.; ANDERSON, J.M. Staphylococcus epidermidis biofilm formation: effects of biomaterial surface chemistry and serum proteins. J. Biomed. Mater. Res. A., v.80, ed.3, p.742-51, 2007.

PETERS, G.; LOCCI, R.; PULVERER , G. Adherence and growth of coagulasenegative staphylococci on surfaces of intravenous catheters. J. Infect., v.146, p.479482, 1982.

PIZZOLITTO, E.L. Contribuição ao estudo in vitro da corrosão induzida por microrganismos sobre liga-metálicas a abase de cobre, de uso na odontologia Modelo experimental com as cepas cariogênicas Streptoccus mutans e Streptococcus sobrinus. Tese (Doutorado) - Instituto de Quimica, Universidade Estadual Paulista, Araraquara, 1997.

PIZZOLITTO, E.L.; PIZZOLITTO, A.C.; POZETTI,G,L. Chemical and Microbiological evaluation of the internal surfaces of aluminium tubes both unlined and lined with expoxi resin by means of the stereoscope and scanning electron microscope . J. Microbiol., v.32, p.340-344, 2001.

PINNA, A.; ZANETTI, S.; SECHI, L.A.; USAI, D.; FALCHI, M.P.; CARTA, F. In vitro adherence of Staphylococcus epidermidis to polymenthyl methacrylate and acrysof intraocular lenses. Ophthalmol., v.107 (supl.6), p.1042-1046, 2000.

PINNA, A.; SECHI, L.A.; ZANETTI, S.; DELOGU, D., CARTA, F. Adherence of ocular isolates of Staphylococcus epidermidis to Acrysof intraocular lenses. A scanning electron microscopy and molecular biology study. Ophthalmol., v.107 (supl.12), p.2162-66, 2000.

POISET, P.; BERGONZI, G.; BALLOCCHI, S.; SCARPIONI, L. Aging of silastic peritoneal catheters. J. Artif. Organs., v.14, p.765-70, 1991.

QIU, Y.; ZHANG, N.; AN, Y.H.; WHEN, X. Biomaterial strategies to reduce implantassociated infecions. J. Artif. Organs., v.30, p.828-41, 2007.

RAAD, I.; COSTERTON, W.; SABHARWAL, U.; SACILOWSKI, M.; ANAISSIE, W.;

BADEY, G.P. Ultrastructural anaysis of indwelling vascular catheters: a quantitative relationship between luminal colonization and duration of placement. J. Infect. Dis., v.168, p.400-407, 1993.

REID, G.; DAVIDSON, R.; DENSTEDT, J.D. XPS, SEM and EDX analysis of conditioning film deposition onto ureteral stents. Surf. Interf. An., v.21, p.581-6, 1994. 
REZENDE, C.M.F.; SILVA, M.C.; LARANJEIRA, M.G.; BORGES, A.P.B. An experimental study of polyurethane of castor-oil plant (Ricinus communis) as a partial substitute of the common calcaneous tendon in rabbits (Oryctogalus cuniculus). Arq. Bras. Med. Vet. Zootec., v.53, n.6, p.695-700, 2001.

RICKERT, D.; LENDLEIN, A.; PETERS, I.; MOSES, M.A.; FRANKE, R.P. Biocompatibility testting of novel multifunctional polymeric biomaterials for tissue engineering applications in head and neck surgery: an overview. J. European Arch. Oto-Rhino-Laryngol., v.263, n.3, 2006.

RONDÓ, W, JR.; VIDARTE, G.; MICHALANY, N. Histologic study of the skin with gold thread implantation. Plas. Recon. Surg., v.97 (supl.1), p.256-257, 1996.

RUSSEL, P.B.; KLINE, J.; YODER, M.C.; POLIN, R. Staphylococcal Adherence to Polyvinyl Chloride and Heparin-Bonded Polyurethane Catheters is Species Dependent and Enhanced by Fibronectin. J. Clinic. Microbiol., v.25, n.6, p.10831087, 1987.

SAUER, K.; CAMPER, A.K.; EHRLICH, G.D.; COSTERTON, J.W.; DAVIES, D.G. Pseudomonas aeruginosa displays multiple phenotypes during development as a biofilm. J. Bacteriol., v.184, p.1140-1154, 2002.

SCHARTZ, R.; MESSANA, J.; HOLMES, C.; WILLIAMS, J. Biofilm formation on peritoneal catheters does not require the presence of infections. Asaio Trans., v.37, p.626-34, 1991.

SHAKENRAAD, J.M.; NOORDMANS, J.; WILDEVUUR, C.R. The effects os protein adsorption on substratum surface free energy, infrared absorption and cell spreading. Biofouling, v.1, p.193-201, 1998.

SIMÕES, M.; PEREIRA, M.O.; VIEIRA, M.J. Monitoring the effects of biocide treatment of Pseudomonas fluorescens biofilms formed under different flow regimes. Water Sciec. and Technol., v.47 (supl.5), p.217-223, 2003.

SOUZA, A.M.G.; BRANDT, C.T.; LIMA, J.A. Biopolímero da Mamona na Reconstrução de Falhas ósseas após Ressecção de tumor ósseo. Acta. Cirurg. Brasileira, v.18 (supl.2), 2003.

STICKLER, D.; MORRIS, N.; MORENO, M.C.; SABBUBA, N. Studies on the formation of crystalline bacterial biofilms on urethral catheters. J. Clin. Microbiol. Infect. Dis., v.17, p.649-652, 1998.

STOCK, J.B. STOCK, A.M.; MOTTONEN, J.M. Signal transduction in bacteria. Nature, v.344, p.395-400, 1990.

STOODLEY, P.; SAUER, K.; DAVIES, D.G.; COSTERTON, J.W. Biofilms as complex differentiated comunities. Rev. Microbiol., v.56, p.187-209, 2002. 
STONE, J.H.; GABRIEL, M.M.; AHEARN, D.G. Adherence of Pseudomonas aeruginosa to inanimate polymers including biomaterials. J. Microbiol. Biotec., v.23, p.713-717, 1999.

STORTI, A.; PIZZOLITTO, A.C.; PIZZOLITTO, E.L. Detection of mixed microbial biofilms on central venous catheters removed from intensive care Unit Patients. J. Microbiol., v.36, p.275-280, 2005.

STURION, D. J.; BUCK, E. L.; TANAKA, N. M.; GERMANI, M. H.; STURION, M. A. T. Uso de polímeros em Medicina Veterinária. Cienc. Biol. Saúde, v. 1, n. 1, p.103$115,1999$.

SULAMANIDZE, M.A.; SHIFFMAN, M.A.; PAIKIDZE, M.D.; SULAMANIDZE, G.M.; GAVASHELI, L.G. Facial Lifting with Aptos Threads. J. Cosmetic Surg. Aesthetic Dermatol., n.4, 2001.

SULAMANIDZE, M.A.; FOURNIER, P.F.; PIKIDZE, T.G.; SULAMANIDZE, G.M. Removal of Facial Soft Tissue Ptosis with Special threads. Dematol. Surg., v.5, 2002.

TAYLOR, S.G.; DWYER, P.J. Chronic groin sepsis following tension-free inguinal hernioplasty. J. Surg., v.86, p.562-5, 1999.

TORTORA, G.J; FUNKE, S.; RAMALHO, L.T.O. Microbiologia. ArtMed, ed.8, p.827, 2000.

VILARINHO, R.H.; HETEM, S.; RAMALHO, L.T.O. Implante de resina de poliuretana vegetal na câmara anterior do olho de camundongo. Odonto 2000, v.1, p.25-29, 1996.

VILLELA, G.G.; BACILA, M.; TALSTADI, H. Bioquímica, 4aa edição, GuanabaraKoogan, 1978.

VON EIFF, C.; KHOEN, W.; BECKER, K.; JANSEN, B. Moderns strategies in the prevention of implant-associated infections. Int. J. Artif. Organs., v.28, p.1146-56, 2005.

YOKOO, S; PIZZOLITTO, A. C; POZETTI, G. L; PIZZOLITTO, E. L. Staphylococcus aureus attachment and biofilm formation on polyethylene terephthalate (PET) used for packaging drugs and cosmetics. Rev. Ciênc. Farm., V.25 (supl.1), p.37-39, 2004.

ZOTOLLA, E.A.; SASAHARA, K.C. Microbial biofilms in the food processing industry. Int. J. Food Microbial., v.23, 1994. 
A - Preparação dos reagentes para observação por meio de microscópio eletrônico de varredura

\section{TAMPÃO FOSFATO 0,2M}

\section{SOLUÇÃO A}

Fosfato monofásico de sódio

$2,76 \mathrm{~g}$.

Água destilada

$100,0 \mathrm{ml}$

\section{SOLUÇÃO B}

Fosfato dibásico de sódio $7,17 \mathrm{~g}$.

Água destilada $100,0 \mathrm{ml}$

TAMPÃO FOSFATO 0,2M e pH 7,1

Solução A

Solução B
$50,0 \mathrm{ml}$

$50,0 \mathrm{ml}$

TAMPÃO FOSFATO 0,1M e pH 7,1

Tampão fosfato $0,2 \mathrm{M} \mathrm{e} \mathrm{pH} \mathrm{7,1}$

$50,0 \mathrm{ml}$

Água destilada

$50,0 \mathrm{ml}$

SOLUÇÃO TAMPÃO 0,1M - GLUTARALDEÍDO A 2,5\%

Tampão $0,1 \mathrm{M} \mathrm{e} \mathrm{pH} \mathrm{7,1}$

$48,5 \mathrm{ml}$ 
B - Soluções de etanol 15-100\%

Solução de etanol a $15 \%$

Álcool etílico absoluto

$15,0 \mathrm{ml}$

Água destilada

$85,0 \mathrm{ml}$

Solução de etanol a $\mathbf{3 0} \%$

Álcool etílico absoluto

$30,0 \mathrm{ml}$

Água destilada

$70,0 \mathrm{ml}$

Solução de etanol a $\mathbf{7 0} \%$

Álcool etílico absoluto $70,0 \mathrm{ml}$

Água destilada

$30,0 \mathrm{ml}$

Solução de etanol a $\mathbf{9 0 \%}$

Álcool etílico absoluto

$90,0 \mathrm{ml}$

Água destilada

$10,0 \mathrm{ml}$

Solução de etanol a $\mathbf{1 0 0 \%}$

Álcool etílico absoluto

$100,0 \mathrm{ml}$ 
C - Preparação de Tampão PBS e solução salina fisiológica esterilizada.

SALINA TAMPONADA COM FOSFATO 0,01M pH 7,2 (Tampão PBS)

Fosfato dibásico de sódio

Fosfato monobásico de sódio

Cloreto de sódio

Água destilada
$2,65 \mathrm{~g}$.

$0,358 \mathrm{~g}$.

$8,18 \mathrm{~g}$.

$1000,0 \mathrm{ml}$

SALINA FISIOLÓGICA

\begin{tabular}{cc}
\hline $\mathrm{NaCl}$ & $8,5 \mathrm{~g}$. \\
Água destilada & $1000,0 \mathrm{ml}$ \\
\hline
\end{tabular}

Homogeneizar até ficar límpido. Autoclavar por 15 minutos a $121^{\circ} \mathrm{C}$. 
D - Unidades formadoras de colônia de S. aureus, S. epidermidis e $P$. aeruginosa sobre a superfície dos fios de poliuretano e polipropileno em 1,5; 4; 24; 48; 72 e 120 horas de incubação.

As Tabelas 10-15 mostram as unidades formadoras de colônia de $S$. aureus, após o contato com a superfície do poliuretano e polipropileno em 1 hora e 30 minutos a 120 horas de incubação.

As Tabelas 16-21 mostram as unidades formadoras de colônia de $S$. epidermidis, após o contato com a superfície do poliuretano e polipropileno em 1 hora e 30 minutos a 120 horas de incubação.

As Tabelas 22-27 mostram as unidades formadoras de colônia de $P$. aeruginosa, após o contato com a superfície do poliuretano e polipropileno em 1 hora e 30 minutos a 120 horas de incubação. 
Tabela 10. Distribuição de células viáveis de $S$. aureus recuperadas após contato com superfície do poliuretano e polipropileno após 1 hora e 30 minutos.

\begin{tabular}{|c|c|c|c|c|c|}
\hline Poliuretano & Repetições & UFC/ml & 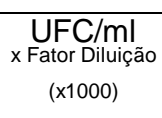 & $\begin{array}{c}\text { Número } \\
\text { total }\end{array}$ & Log UFC/ml \\
\hline \multirow{3}{*}{ A1 } & 1 & 10 & 10.000 & $1 \times 10^{4}$ & 4,0 \\
\hline & 2 & 10 & 10.000 & $1 \times 10^{4}$ & 4,0 \\
\hline & 3 & 10 & 10.000 & $1 \times 10^{4}$ & 4,0 \\
\hline \multirow{3}{*}{ A2 } & 1 & 0 & 0 & 0 & 0 \\
\hline & 2 & 10 & 10.000 & $1 \times 10^{4}$ & 4,0 \\
\hline & 3 & 0 & 0 & 0 & 0 \\
\hline \multirow{3}{*}{ A3 } & 1 & 0 & 0 & 0 & 0 \\
\hline & 2 & 0 & 0 & 0 & 0 \\
\hline & 3 & 0 & 0 & 0 & 0 \\
\hline Polipropileno & Repetições & $\mathrm{UFC} / \mathrm{ml}$ & $\underset{\substack{U \text { Fator Diluicăà } \\
\text { (x1000) }}}{\mathrm{UFC} / \mathrm{ml}}$ & $\begin{array}{c}\text { Número } \\
\text { total }\end{array}$ & Log UFC/ ml \\
\hline \multirow{3}{*}{$\mathrm{A} 1$} & 1 & 30 & 30.000 & $3 \times 10^{4}$ & 4,477 \\
\hline & 2 & 10 & 10.000 & $1 \times 10^{4}$ & 4,0 \\
\hline & 3 & 0 & 0 & 0 & 0 \\
\hline \multirow{3}{*}{$\mathrm{A} 2$} & 1 & 0 & 0 & 0 & 0 \\
\hline & 2 & 0 & 0 & 0 & 0 \\
\hline & 3 & 0 & 0 & 0 & 0 \\
\hline \multirow{3}{*}{ A3 } & 1 & 10 & 10.000 & $1 \times 10^{4}$ & 4,0 \\
\hline & 2 & 30 & 30.000 & $3 \times 10^{4}$ & 4,477 \\
\hline & 3 & 0 & 0 & 0 & 0 \\
\hline
\end{tabular}

Tabela 11. Distribuição de células viáveis de $S$. aureus recuperadas após contato com a superfície do poliuretano e polipropileno após 4 horas.

\begin{tabular}{|c|c|c|c|c|c|}
\hline Poliuretano & Repetições & $\mathrm{UFC} / \mathrm{ml}$ & $\begin{array}{c}\mathrm{UFC} / \mathrm{ml} \\
\text { x Fator Diluição } \\
(\times 1000)\end{array}$ & $\begin{array}{c}\text { Número } \\
\text { total }\end{array}$ & Log UFC/ ml \\
\hline \multirow{3}{*}{ A1 } & 1 & 104 & 104.000 & $10,4 \times 10^{4}$ & 5,017 \\
\hline & 2 & 115 & 115.000 & $11,5 \times 10^{4}$ & 5,060 \\
\hline & 3 & 98 & 98.000 & $9,8 \times 10^{4}$ & 4,991 \\
\hline \multirow{3}{*}{ A2 } & 1 & 120 & 120.000 & $12,0 \times 10^{4}$ & 5,079 \\
\hline & 2 & 111 & 111.000 & $11,1 \times 10^{4}$ & 5,045 \\
\hline & 3 & 128 & 128.000 & $12,8 \times 10^{4}$ & 5,107 \\
\hline \multirow{3}{*}{ A3 } & 1 & 110 & 110.000 & $11 \times 10^{4}$ & 5,041 \\
\hline & 2 & 95 & 95.000 & $9,5 \times 10^{4}$ & 4,977 \\
\hline & 3 & 124 & 124.000 & $12,4 \times 10^{4}$ & 5,093 \\
\hline Polipropileno & Repetições & $\mathrm{UFC} / \mathrm{ml}$ & $\begin{array}{c}\text { UFC/ } \mathrm{ml} \\
\times \text { Fator Diluição } \\
(\times 1000)\end{array}$ & $\begin{array}{l}\text { Número } \\
\text { total }\end{array}$ & Log UFC/ ml \\
\hline \multirow{3}{*}{ A1 } & 1 & 63 & 63.000 & $6.3 \times 10^{4}$ & 4,799 \\
\hline & 2 & 81 & 81.000 & $8,1 \times 10^{4}$ & 4,908 \\
\hline & 3 & 80 & 80.000 & $8 \times 10^{4}$ & 4,903 \\
\hline \multirow{3}{*}{ A2 } & 1 & 64 & 64.000 & $6,4 \times 10^{4}$ & 4,806 \\
\hline & 2 & 55 & 55.000 & $5,5 \times 10^{4}$ & 4,740 \\
\hline & 3 & 74 & 74.000 & $7,4 \times 10^{4}$ & 4,869 \\
\hline \multirow{3}{*}{ A3 } & 1 & 70 & 70.000 & $7 \times 10^{4}$ & 4,845 \\
\hline & 2 & 68 & 68.000 & $6,8 \times 10^{4}$ & 4,832 \\
\hline & 3 & 52 & 52.000 & $5,2 \times 10^{4}$ & 4,716 \\
\hline
\end{tabular}


Tabela 12. Distribuição de células viáveis de $S$. aureus recuperadas após contato com a superfície do poliuretano e polipropileno após 24 horas.

\begin{tabular}{|c|c|c|c|c|c|}
\hline Poliuretano & Repetições & $\mathrm{UFC} / \mathrm{ml}$ & $\begin{array}{c}\text { XFClom } \mathrm{ml} \\
\text { x Fator Diluição } \\
(\times 1000)\end{array}$ & $\begin{array}{c}\text { Número } \\
\text { total }\end{array}$ & Log UFC/ ml \\
\hline \multirow{3}{*}{ A1 } & 1 & 280 & 280.000 & $28,0 \times 10^{4}$ & 5,477 \\
\hline & 2 & 290 & 290.000 & $29,0 \times 10^{4}$ & 5,462 \\
\hline & 3 & 288 & 288.000 & $28,8 \times 10^{4}$ & 5,459 \\
\hline \multirow{3}{*}{ A2 } & 1 & 330 & 330.000 & $33,0 \times 10^{4}$ & 5,518 \\
\hline & 2 & 291 & 291.000 & $29,1 \times 10^{4}$ & 5,463 \\
\hline & 3 & 320 & 320.000 & $32,0 \times 10^{4}$ & 5,505 \\
\hline \multirow{3}{*}{ A3 } & 1 & 270 & 270.000 & $27,0 \times 10^{4}$ & 5,431 \\
\hline & 2 & 300 & 300.000 & $30,0 \times 10^{4}$ & 5,477 \\
\hline & 3 & 340 & 340.000 & $34,0 \times 10^{4}$ & 5,531 \\
\hline Polipropileno & Repetições & UFC/ ml & $\begin{array}{c}\text { XFC/ mator Diluição } \\
(\times 1000)\end{array}$ & $\begin{array}{c}\text { Número } \\
\text { total }\end{array}$ & Log UFC/ ml \\
\hline \multirow{3}{*}{ A } & 1 & 600 & 600.000 & $60,0 \times 10^{4}$ & 5,778 \\
\hline & 2 & 530 & 530.000 & $53,0 \times 10^{4}$ & 5,724 \\
\hline & 3 & 780 & 780.000 & $78,0 \times 10^{4}$ & 5,892 \\
\hline \multirow{3}{*}{ B } & 1 & 800 & 800.000 & $8,0 \times 10^{4}$ & 5,903 \\
\hline & 2 & 740 & 740.000 & $74,0 \times 10^{4}$ & 5,869 \\
\hline & 3 & 890 & 890.000 & $89,0 \times 10^{4}$ & 5,949 \\
\hline \multirow{3}{*}{ C } & 1 & 810 & 810.000 & $81,0 \times 10^{4}$ & 5,908 \\
\hline & 2 & 930 & 930.000 & $93,0 \times 10^{4}$ & 5,968 \\
\hline & 3 & 860 & 860.000 & $86,0 \times 10^{4}$ & 5,934 \\
\hline
\end{tabular}

Tabela 13. Distribuição de células viáveis de $S$. aureus recuperadas após contato com a superfície do poliuretano e polipropileno após 48 horas.

\begin{tabular}{|c|c|c|c|c|c|}
\hline Poliuretano & Repetições & UFC/ ml & $\begin{array}{c}\text { UFC/mI } \\
\times \text { F Fator Diluiça } \\
(\times 1000)\end{array}$ & $\begin{array}{c}\text { Número } \\
\text { total }\end{array}$ & Log UFC/ ml \\
\hline \multirow{3}{*}{ A } & 1 & 220 & 220.000 & $22,0 \times 10^{4}$ & 5,342 \\
\hline & 2 & 290 & 290.00 & $29,0 \times 10^{4}$ & 5,462 \\
\hline & 3 & 340 & 340.00 & $34,0 \times 10^{4}$ & 5,531 \\
\hline \multirow{3}{*}{ B } & 1 & 390 & 390.000 & $39,0 \times 10^{4}$ & 5,591 \\
\hline & 2 & 420 & 420.000 & $42,0 \times 10^{4}$ & 5,623 \\
\hline & 3 & 470 & 470.000 & $47,0 \times 10^{4}$ & 5,672 \\
\hline \multirow{3}{*}{ C } & 1 & 450 & 450.000 & $45,0 \times 10^{4}$ & 5,653 \\
\hline & 2 & 520 & 520.000 & $52,0 \times 10^{4}$ & 5,716 \\
\hline & 3 & 400 & 400.000 & $40,0 \times 10^{4}$ & 5,602 \\
\hline Polipropileno & Repetições & $\mathrm{UFC} / \mathrm{ml}$ & 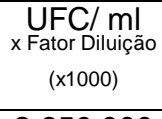 & $\begin{array}{l}\text { Número } \\
\text { total }\end{array}$ & Log UFC/ ml \\
\hline \multirow{3}{*}{ A } & 1 & 2650 & 2.650 .000 & $265,0 \times 10^{4}$ & 6,423 \\
\hline & 2 & 2600 & 2.600 .000 & $260,0 \times 10^{4}$ & 6,414 \\
\hline & 3 & 2130 & 2.130 .000 & $213,0 \times 10^{4}$ & 6,328 \\
\hline \multirow{3}{*}{ B } & 1 & 3400 & 3.400 .000 & $340,0 \times 10^{4}$ & 6,531 \\
\hline & 2 & 3340 & 3.340 .000 & $334,0 \times 10^{4}$ & 6,523 \\
\hline & 3 & 3400 & 3.400 .000 & $340,0 \times 10^{4}$ & 6,531 \\
\hline \multirow{3}{*}{ C } & 1 & 2280 & 2.280 .000 & $228,0 \times 10^{4}$ & 6,357 \\
\hline & 2 & 2760 & 2.760 .000 & $276,0 \times 10^{4}$ & 6,440 \\
\hline & 3 & 2240 & 2.240 .000 & $224,0 \times 10^{4}$ & 6,350 \\
\hline
\end{tabular}


Tabela 14. Distribuição de células viáveis de $S$. aureus recuperadas após contato com a superfície do poliuretano e polipropileno após 72 horas.

\begin{tabular}{|c|c|c|c|c|c|}
\hline Poliuretano & Repetições & $\mathrm{UFC} / \mathrm{ml}$ & $\begin{array}{c}\mathrm{UFC} / \mathrm{ml} \\
\times \text { Fator Diluição } \\
(\times 1000)\end{array}$ & $\begin{array}{c}\text { Número } \\
\text { total }\end{array}$ & Log UFC/ ml \\
\hline \multirow{3}{*}{$\mathrm{A} 1$} & 1 & 330 & 330.000 & $33,0 \times 10^{4}$ & 5,518 \\
\hline & 2 & 380 & 380.000 & $38,0 \times 10^{4}$ & 5,579 \\
\hline & 3 & 451 & 451.000 & $45,1 \times 10^{4}$ & 5,654 \\
\hline \multirow{3}{*}{ A2 } & 1 & 500 & 500.000 & $50,0 \times 10^{4}$ & 5,698 \\
\hline & 2 & 440 & 440.000 & $44,0 \times 10^{4}$ & 5,643 \\
\hline & 3 & 520 & 520.000 & $52,0 \times 10^{4}$ & 5,716 \\
\hline \multirow{3}{*}{ A3 } & 1 & 230 & 230.000 & $23,0 \times 10^{4}$ & 5,361 \\
\hline & 2 & 270 & 270.000 & $27,0 \times 10^{4}$ & 5,431 \\
\hline & 3 & 310 & 310.000 & $31,0 \times 10^{4}$ & 5,491 \\
\hline Polipropileno & Repetições & UFC/ ml & $\begin{array}{c}\text { UFC/m mator Diluição } \\
\text { (x1000) }\end{array}$ & $\begin{array}{l}\text { Número } \\
\text { total }\end{array}$ & Log UFC/ ml \\
\hline \multirow{3}{*}{ A1 } & 1 & 3160 & 3.160 .000 & $316,0 \times 10^{4}$ & 6,499 \\
\hline & 2 & 3920 & 3.920 .000 & $392,0 \times 10^{4}$ & 6,593 \\
\hline & 3 & 3720 & 3.720 .000 & $372,0 \times 10^{4}$ & 6,570 \\
\hline \multirow{3}{*}{ A2 } & 1 & 2040 & 2.040 .000 & $204,0 \times 10^{4}$ & 6,309 \\
\hline & 2 & 2200 & 2.200 .000 & $220,0 \times 10^{4}$ & 6,342 \\
\hline & 3 & 2000 & 2.000 .000 & $200,0 \times 10^{4}$ & 6,301 \\
\hline \multirow{3}{*}{ A3 } & 1 & 2120 & 2.120 .000 & $212,0 \times 10^{4}$ & 6,326 \\
\hline & 2 & 2520 & 2.520 .000 & $252,0 \times 10^{4}$ & 6,401 \\
\hline & 3 & 2400 & 2.400 .000 & $240,0 \times 10^{4}$ & 6,380 \\
\hline
\end{tabular}

Tabela 15. Distribuição de células viáveis de $S$. aureus recuperadas após contato com a superfície do poliuretano e polipropileno após 120 horas.

\begin{tabular}{|c|c|c|c|c|c|}
\hline Poliuretano & Repetições & $\mathrm{UFC} / \mathrm{ml}$ & $\begin{array}{c}\mathrm{UFC} / \mathrm{ml} \\
\text { x Fator Diluição } \\
(\times 1000)\end{array}$ & $\begin{array}{c}\text { Número } \\
\text { total }\end{array}$ & Log UFC/ ml \\
\hline A1 & $\begin{array}{l}1 \\
2 \\
3\end{array}$ & $\begin{array}{l}580 \\
610 \\
700\end{array}$ & $\begin{array}{l}580.000 \\
610.000 \\
700.000\end{array}$ & $\begin{array}{l}58,0 \times 10^{4} \\
61,0 \times 10^{4} \\
70,0 \times 10^{4}\end{array}$ & $\begin{array}{l}5,763 \\
5,785 \\
5,845\end{array}$ \\
\hline A2 & $\begin{array}{l}1 \\
2 \\
3\end{array}$ & $\begin{array}{l}690 \\
600 \\
520\end{array}$ & $\begin{array}{l}690.000 \\
600.000 \\
520.000\end{array}$ & $\begin{array}{l}69,0 \times 10^{4} \\
60,0 \times 10^{4} \\
52,0 \times 10^{4}\end{array}$ & $\begin{array}{l}5,838 \\
5,778 \\
5,716\end{array}$ \\
\hline A3 & $\begin{array}{l}1 \\
2 \\
3\end{array}$ & $\begin{array}{l}550 \\
512 \\
640\end{array}$ & $\begin{array}{l}550.000 \\
512.000 \\
640.000\end{array}$ & $\begin{array}{l}55,0 \times 10^{4} \\
51,2 \times 10^{4} \\
64,0 \times 10^{4}\end{array}$ & $\begin{array}{l}5,740 . \\
5,709 \\
5,806\end{array}$ \\
\hline Polipropileno & Repetições & $\mathrm{UFC} / \mathrm{ml}$ & $\begin{array}{c}\mathrm{UFC} / \mathrm{ml} \\
\times \text { Fator Diluição } \\
(\times 1000)\end{array}$ & $\begin{array}{c}\text { Número } \\
\text { total }\end{array}$ & Log UFC/ ml \\
\hline A1 & $\begin{array}{l}1 \\
2 \\
3\end{array}$ & $\begin{array}{l}2900 \\
2800 \\
2500\end{array}$ & $\begin{array}{l}2.900 .000 \\
2.800 .000 \\
2.500 .000\end{array}$ & $\begin{array}{l}290,0 \times 10^{4} \\
280,0 \times 10^{4} \\
250,0 \times 10^{4}\end{array}$ & $\begin{array}{l}6,462 \\
6,447 \\
6,397\end{array}$ \\
\hline A2 & $\begin{array}{l}1 \\
2 \\
3\end{array}$ & $\begin{array}{l}2400 \\
2600 \\
2080\end{array}$ & $\begin{array}{l}2.400 .000 \\
2.600 .000 \\
2.080 .000\end{array}$ & $\begin{array}{l}240,0 \times 10^{4} \\
260,0 \times 10^{4} \\
200,0 \times 10^{4}\end{array}$ & $\begin{array}{l}6,380 \\
6,414 \\
6,318\end{array}$ \\
\hline A3 & $\begin{array}{l}1 \\
2 \\
3\end{array}$ & $\begin{array}{l}3120 \\
3280 \\
3120\end{array}$ & $\begin{array}{l}3.120 .000 \\
3.280 .000 \\
3.120 .000\end{array}$ & $\begin{array}{l}312,0 \times 10^{4} \\
328,0 \times 10^{4} \\
312,0 \times 10^{4}\end{array}$ & $\begin{array}{l}6,494 \\
6,515 \\
6,570\end{array}$ \\
\hline
\end{tabular}


Tabela 16. Distribuição de células viáveis de $S$. epidermidis recuperadas após contato com a superfície do poliuretano e polipropileno após 1 hora e 30 minutos.

\begin{tabular}{|c|c|c|c|c|c|}
\hline Poliuretano & Repetições & $\mathrm{UFC} / \mathrm{ml}$ & $\begin{array}{c}\mathrm{UFC/ml} \\
\text { x Fator Diluição } \\
\text { (x1000) }\end{array}$ & $\begin{array}{c}\text { Número } \\
\text { total }\end{array}$ & Log UFC/ ml \\
\hline \multirow{3}{*}{ A1 } & 1 & 20 & 20.000 & $2 \times 10^{4}$ & 4,3 \\
\hline & 2 & 0 & 0 & 0 & 0 \\
\hline & 3 & 0 & 0 & 0 & 0 \\
\hline \multirow{3}{*}{$\mathrm{A} 2$} & 1 & 10 & 10.000 & $1 \times 10^{4}$ & 4,0 \\
\hline & 2 & 10 & 10.000 & $1 \times 10^{4}$ & 4,0 \\
\hline & 3 & 0 & 0 & 0 & 0 \\
\hline \multirow{3}{*}{ A3 } & 1 & 0 & 0 & 0 & 0 \\
\hline & 2 & 10 & 10.000 & $1 \times 10^{4}$ & 4,0 \\
\hline & 3 & 0 & 0 & 0 & 0 \\
\hline Polipropileno & Repetições & $\mathrm{UFC} / \mathrm{ml}$ & $\begin{array}{c}\text { UFC/ml } \\
\text { x Fator Diluição } \\
(\times 1000)\end{array}$ & $\begin{array}{c}\text { Número } \\
\text { total }\end{array}$ & Log UFC/ ml \\
\hline \multirow{3}{*}{ A1 } & 1 & 20 & 20.000 & $2 \times 10^{4}$ & 4,3 \\
\hline & 2 & 10 & 10.000 & $1 \times 10^{4}$ & 4,0 \\
\hline & 3 & 10 & 10.000 & $1 \times 10^{4}$ & 4,0 \\
\hline \multirow{3}{*}{ A2 } & 1 & 11 & 11.000 & $1,1 \times 10^{4}$ & 4,04 \\
\hline & 2 & 15 & 15.000 & $1,5 \times 10^{4}$ & 4,17 \\
\hline & 3 & 10 & 10.000 & $1 \times 10^{4}$ & 4,0 \\
\hline \multirow{3}{*}{ A3 } & 1 & 0 & 0 & 0 & 0 \\
\hline & 2 & 20 & 20.000 & $2 \times 10^{4}$ & 4,3 \\
\hline & 3 & 20 & 20.000 & $2 \times 10^{4}$ & 4,3 \\
\hline
\end{tabular}

Tabela 17. Distribuição de células viáveis de $S$. epidermidis recuperadas após contato com a superfície do poliuretano e polipropileno após 4 horas.

\begin{tabular}{|c|c|c|c|c|c|}
\hline Poliuretano & Repetições & UFC/ ml & $\begin{array}{c}\text { UFC/ml } \\
\times \text { Fator Diluiçao } \\
(\times 1000)\end{array}$ & $\begin{array}{c}\text { Número } \\
\text { total }\end{array}$ & Log UFC/ ml \\
\hline A1 & $\begin{array}{l}1 \\
2 \\
3\end{array}$ & $\begin{array}{c}97 \\
115 \\
93\end{array}$ & $\begin{array}{c}97.000 \\
115.000 \\
93.000\end{array}$ & $\begin{array}{c}9,7 \times 10^{4} \\
11,5 \times 10^{4} \\
9,3 \times 10^{4}\end{array}$ & $\begin{array}{l}4,986 \\
5,060 \\
4,968\end{array}$ \\
\hline A2 & $\begin{array}{l}1 \\
2 \\
3\end{array}$ & $\begin{array}{l}110 \\
126 \\
120\end{array}$ & $\begin{array}{l}110.000 \\
126.000 \\
120.000\end{array}$ & $\begin{array}{c}11 \times 10^{4} \\
12,6 \times 10^{4} \\
12 \times 10^{4}\end{array}$ & $\begin{array}{l}5,041 \\
5,100 \\
5,079\end{array}$ \\
\hline A3 & $\begin{array}{l}1 \\
2 \\
3\end{array}$ & $\begin{array}{l}90 \\
86 \\
97\end{array}$ & $\begin{array}{l}90.000 \\
86.000 \\
97.000\end{array}$ & $\begin{array}{c}9 \times 10^{4} \\
8,6 \times 10^{4} \\
9,7 \times 10^{4}\end{array}$ & $\begin{array}{l}4,954 \\
4,934 \\
4,986\end{array}$ \\
\hline Polipropileno & Repetições & UFC/ ml & $\begin{array}{l}\text { UFC/ ml } \\
\text { x Fator Diluição } \\
(\times 1000)\end{array}$ & $\begin{array}{c}\text { Número } \\
\text { total }\end{array}$ & Log UFC/ ml \\
\hline A & $\begin{array}{l}1 \\
2 \\
3\end{array}$ & $\begin{array}{l}33 \\
26 \\
23\end{array}$ & $\begin{array}{l}33.000 \\
26.000 \\
23.000\end{array}$ & $\begin{array}{l}3,3 \times 10^{4} \\
2,6 \times 10^{4} \\
2,3 \times 10^{4}\end{array}$ & $\begin{array}{l}4,518 \\
4,414 \\
4,361\end{array}$ \\
\hline B & $\begin{array}{l}1 \\
2 \\
3\end{array}$ & $\begin{array}{l}20 \\
27 \\
24\end{array}$ & $\begin{array}{l}20.000 \\
27.000 \\
24.000\end{array}$ & $\begin{array}{l}2,0 \times 10^{4} \\
2,7 \times 10^{4} \\
2,4 \times 10^{4}\end{array}$ & $\begin{array}{l}4,301 \\
4,431 \\
4,380\end{array}$ \\
\hline C & $\begin{array}{l}1 \\
2 \\
3\end{array}$ & $\begin{array}{l}44 \\
33 \\
38\end{array}$ & $\begin{array}{l}44.000 \\
33.000 \\
38.000\end{array}$ & $\begin{array}{l}4,4 \times 10^{4} \\
3,3 \times 10^{4} \\
3,8 \times 10^{4}\end{array}$ & $\begin{array}{l}4,643 \\
4,518 \\
4,579\end{array}$ \\
\hline
\end{tabular}


Tabela 18. Distribuição de células viáveis de $S$. epidermidis recuperadas após contato com a superfície do poliuretano e polipropileno após 24 horas.

\begin{tabular}{|c|c|c|c|c|c|}
\hline Poliuretano & Repetições & UFC/ ml & $\begin{array}{c}\mathrm{UFC} / \mathrm{ml} \\
\text { x Fator Diluição } \\
\text { (x1000) }\end{array}$ & $\begin{array}{c}\text { Número } \\
\text { total }\end{array}$ & Log UFC/ ml \\
\hline \multirow{3}{*}{ A1 } & 1 & 120 & 120.000 & $12,0 \times 10^{4}$ & 5,079 \\
\hline & 2 & 213 & 213.000 & $21,3 \times 10^{4}$ & 5,328 \\
\hline & 3 & 275 & 275.000 & $27,5 \times 10^{4}$ & 5,439 \\
\hline \multirow{3}{*}{ A2 } & 1 & 150 & 150.000 & $15,0 \times 10^{4}$ & 5,176 \\
\hline & 2 & 240 & 240.000 & $24,0 \times 10^{4}$ & 5,380 \\
\hline & 3 & 210 & 210.000 & $21,0 \times 10^{4}$ & 5,322 \\
\hline \multirow{3}{*}{ A3 } & 1 & 107 & 107.000 & $10,7 \times 10^{4}$ & 5,029 \\
\hline & 2 & 97 & 97.000 & $9,7 \times 10^{4}$ & 4,986 \\
\hline & 3 & 120 & 120.000 & $12,0 \times 10^{4}$ & 5,079 \\
\hline Polipropileno & Repetições & UFC/ ml & $\begin{array}{l}\text { XFC/m ml } \\
\text { x Fator Diluição } \\
\text { (x1000) }\end{array}$ & $\begin{array}{c}\text { Número } \\
\text { total }\end{array}$ & Log UFC/ ml \\
\hline \multirow{3}{*}{$\mathrm{A} 1$} & 1 & 384 & 384.000 & $38,4 \times 10^{4}$ & 5,579 \\
\hline & 2 & 320 & 320.000 & $32,0 \times 10^{4}$ & 5,505 \\
\hline & 3 & 290 & 290.000 & $29,0 \times 10^{4}$ & 5,462 \\
\hline \multirow{3}{*}{ A2 } & 1 & 360 & 360.000 & $36,0 \times 10^{4}$ & 5,556 \\
\hline & 2 & 270 & 270.000 & $27,0 \times 10^{4}$ & 5,431 \\
\hline & 3 & 294 & 294.000 & $29,4 \times 10^{4}$ & 5,468 \\
\hline \multirow{3}{*}{ A3 } & 1 & 330 & 330.000 & $33,0 \times 10^{4}$ & 5,518 \\
\hline & 2 & 350 & 350.000 & $35,0 \times 10^{4}$ & 5,544 \\
\hline & 3 & 280 & 280.000 & $28,0 \times 10^{4}$ & 5,447 \\
\hline
\end{tabular}

Tabela 19. Distribuição de células viáveis de $S$. epidermidis recuperadas após contato com a superfície do poliuretano e polipropileno após 48 horas.

\begin{tabular}{|c|c|c|c|c|c|}
\hline Poliuretano & Repetições & UFC/ ml & $\begin{array}{c}\text { UFC/mI } \\
\times \text { Fator Diluiçăo } \\
\text { (x1000) }\end{array}$ & $\begin{array}{c}\text { Número } \\
\text { total }\end{array}$ & Log UFC/ ml \\
\hline \multirow{4}{*}{ A1 } & 1 & 300 & 300.000 & $30,0 \times 10^{4}$ & 5,477 \\
\hline & 2 & 320 & 320.000 & $32,0 \times 10^{4}$ & 5,505 \\
\hline & 3 & 236 & 236.000 & $23,6 \times 10^{4}$ & 5,372 \\
\hline & 1 & 310 & 310.000 & $31,0 \times 10^{4}$ & 5,491 \\
\hline \multirow[t]{3}{*}{ A2 } & 2 & 270 & 270.000 & $27,0 \times 10^{4}$ & 5,431 \\
\hline & 3 & 350 & 350.000 & $35,0 \times 10^{4}$ & 5,544 \\
\hline & 1 & 335 & 335.000 & $33,5 \times 10^{4}$ & 5,525 \\
\hline \multirow[t]{2}{*}{ A3 } & 2 & 280 & 280.000 & $38,0 \times 10^{4}$ & 5,447 \\
\hline & 3 & 270 & 270.000 & $27,0 \times 10^{4}$ & 5,431 \\
\hline Polipropileno & Repetições & UFC/ ml & $\begin{array}{c}\mathrm{UFC} / \mathrm{ml} \\
\text { x Fator Diluição } \\
\text { (x1000) }\end{array}$ & $\begin{array}{c}\text { Número } \\
\text { total }\end{array}$ & Log UFC/ ml \\
\hline \multirow{3}{*}{ A1 } & 1 & 60 & 60.000 & $6,0 \times 10^{4}$ & 4,778 \\
\hline & 2 & 73 & 73.000 & $7,3 \times 10^{4}$ & 4,863 \\
\hline & 3 & 70 & 70.000 & $7,0 \times 10^{4}$ & 4,845 \\
\hline \multirow{3}{*}{ A2 } & 1 & 68 & 68.000 & $6,8 \times 10^{4}$ & 4,832 \\
\hline & 2 & 79 & 79.000 & $7,9 \times 10^{4}$ & $\begin{array}{l}4,897 \\
\end{array}$ \\
\hline & 3 & 82 & 82.000 & $8,2 \times 10^{4}$ & 4,913 \\
\hline \multirow{3}{*}{ A3 } & 1 & 73 & 73.000 & $7,3 \times 10^{4}$ & 4,863 \\
\hline & 2 & 75 & 75.000 & $7,5 \times 10^{4}$ & 4,875 \\
\hline & 3 & 59 & 59.000 & $5,9 \times 10^{4}$ & 4,770 \\
\hline
\end{tabular}


Tabela 20. Distribuição de células viáveis de $S$. epidermidis recuperadas após contato com a superfície do poliuretano e polipropileno após 72 horas.

\begin{tabular}{|c|c|c|c|c|c|}
\hline Poliuretano & Repetições & UFC/ ml & $\begin{array}{l}\text { UFC/ ml } \\
\text { x Fator Diluição } \\
\text { (x1000) }\end{array}$ & $\begin{array}{c}\text { Número } \\
\text { total }\end{array}$ & Log UFC/ ml \\
\hline \multirow{3}{*}{ A1 } & 1 & 51 & 51.000 & $5,1 \times 10^{4}$ & 4,707 \\
\hline & 2 & 38 & 38.000 & $3,8 \times 10^{4}$ & 4,579 \\
\hline & 3 & 42 & 42.000 & $4,2 \times 10^{4}$ & 4,623 \\
\hline \multirow{3}{*}{ A2 } & 1 & 50 & 50.000 & $5,0 \times 10^{4}$ & 4,698 \\
\hline & 2 & 46 & 46.000 & $4,6 \times 10^{4}$ & 4,662 \\
\hline & 3 & 57 & 57.000 & $5,7 \times 10^{4}$ & 4,755 \\
\hline \multirow{3}{*}{ A3 } & 1 & 65 & 65.000 & $6,5 \times 10^{4}$ & 4,812 \\
\hline & 2 & 42 & 42.000 & $4,2 \times 10^{4}$ & 4,623 \\
\hline & 3 & 58 & 58.000 & $5,8 \times 10^{4}$ & 4,763 \\
\hline Polipropileno & Repetições & UFC/ ml & $\underset{\substack{\mathrm{U} \text { Fator Diluição } \\
(\times 1000)}}{\mathrm{UFC} / \mathrm{ml}}$ & $\begin{array}{c}\text { Número } \\
\text { total }\end{array}$ & Log UFC/ ml \\
\hline \multirow{3}{*}{ A1 } & 1 & 98 & 98.000 & $9,8 \times 10^{4}$ & 4,991 \\
\hline & 2 & 85 & 85.000 & $8,5 \times 10^{4}$ & 4,929 \\
\hline & 3 & 70 & 70.000 & $7,0 \times 10^{4}$ & 4,845 \\
\hline \multirow{3}{*}{ A2 } & 1 & 102 & 102.000 & $10,2 \times 10^{4}$ & 5,008 \\
\hline & 2 & 90 & 90.000 & $9,0 \times 10^{4}$ & 4,954 \\
\hline & 3 & 87 & 87.000 & $8,7 \times 10^{4}$ & 4,939 \\
\hline \multirow{3}{*}{ A3 } & 1 & 95 & 95.000 & $9,5 \times 10^{4}$ & 4,977 \\
\hline & 2 & 83 & 83.000 & $8,3 \times 10^{4}$ & 4,919 \\
\hline & 3 & 90 & 90.000 & $9,0 \times 10^{4}$ & 4,954 \\
\hline
\end{tabular}

Tabela 21. Distribuição de células viáveis de $S$. epidermidis recuperadas após contato com a superfície do poliuretano e polipropileno após 120 horas.

\begin{tabular}{|c|c|c|c|c|c|}
\hline Poliuretano & Repetições & $\mathrm{UFC} / \mathrm{ml}$ & $\begin{array}{c}\text { XFC/m } \mathrm{ml} \\
\text { x Fator Diluição } \\
(\times 1000)\end{array}$ & $\begin{array}{c}\text { Número } \\
\text { total }\end{array}$ & Log UFC/ ml \\
\hline \multirow{3}{*}{ A1 } & 1 & 43 & 43.000 & $4,3 \times 10^{4}$ & 4,633 \\
\hline & 2 & 48 & 48.000 & $4,8 \times 10^{4}$ & 4,681 \\
\hline & 3 & 39 & 39.000 & $3,9 \times 10^{4}$ & 4,591 \\
\hline \multirow{3}{*}{ A2 } & 1 & 37 & 37.000 & $3,7 \times 10^{4}$ & 4,568 \\
\hline & 2 & 46 & 46.000 & $4,6 \times 10^{4}$ & 4,662 \\
\hline & 3 & 41 & 41.000 & $4,1 \times 10^{4}$ & 4,612 \\
\hline \multirow{3}{*}{ A3 } & 1 & 42 & 42.000 & $4,2 \times 10^{4}$ & 4,623 \\
\hline & 2 & 35 & 35.000 & $3,5 \times 10^{4}$ & 4,544 \\
\hline & 3 & 40 & 40.000 & $4,0 \times 10^{4}$ & 4,602 \\
\hline Polipropileno & Repetições & $\mathrm{UFC} / \mathrm{ml}$ & $\begin{array}{c}\text { UFC/mitor Diluição } \\
\text { (x1000) }\end{array}$ & $\begin{array}{c}\text { Número } \\
\text { total }\end{array}$ & Log UFC/ ml \\
\hline \multirow{3}{*}{ A1 } & 1 & 116 & 116.000 & $11,6 \times 10^{4}$ & 5,064 \\
\hline & 2 & 134 & 134.000 & $13,4 \times 10^{4}$ & 5,127 \\
\hline & 3 & 127 & 127.000 & $12,7 \times 10^{4}$ & 5,103 \\
\hline \multirow{3}{*}{ A2 } & 1 & 170 & 170.000 & $17,0 \times 10^{4}$ & 5,230 \\
\hline & 2 & 138 & 138.000 & $13,8 \times 10^{4}$ & 5,139 \\
\hline & 3 & 139 & 139.000 & $13,9 \times 10^{4}$ & 5,143 \\
\hline \multirow{3}{*}{ A3 } & 1 & 83 & 83.000 & $8,3 \times 10^{4}$ & 4,919 \\
\hline & 2 & 97 & 97.000 & $9,7 \times 10^{4}$ & 4,986 \\
\hline & 3 & 78 & 78.000 & $7,8 \times 10^{4}$ & 4,892 \\
\hline
\end{tabular}


Tabela 22. Distribuição de células viáveis de $P$. aeruginosa recuperadas após contato com a superfície do poliuretano e polipropileno após 1 hora e 30 minutos.

\begin{tabular}{|c|c|c|c|c|c|}
\hline Poliuretano & Repetições & UFC/ ml & 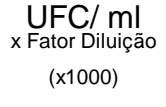 & $\begin{array}{c}\text { Número } \\
\text { total }\end{array}$ & Log UFC/ ml \\
\hline \multirow{3}{*}{$\mathrm{A} 1$} & 1 & 160 & 160.000 & $16,0 \times 10^{4}$ & 5,204 \\
\hline & 2 & 170 & 170.000 & $17,0 \times 10^{4}$ & 5,230 \\
\hline & 3 & 190 & 190.000 & $19,0 \times 10^{4}$ & 4,954 \\
\hline \multirow{3}{*}{$\mathrm{A} 2$} & 1 & 170 & 170.000 & $17,0 \times 10^{4}$ & 5,230 \\
\hline & 2 & 100 & 100.000 & $10,0 \times 10^{4}$ & 5,0 \\
\hline & 3 & 160 & 160.000 & $16,0 \times 10^{4}$ & 5,204 \\
\hline \multirow{3}{*}{ A3 } & 1 & 90 & 90.000 & $9,0 \times 10^{4}$ & 4,954 \\
\hline & 2 & 70 & 70.000 & $7,0 \times 10^{4}$ & 4,845 \\
\hline & 3 & 120 & 120.000 & $12,0 \times 10^{4}$ & 5,079 \\
\hline Polipropileno & Repetições & UFC/ ml & 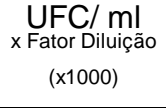 & $\begin{array}{c}\text { Número } \\
\text { total }\end{array}$ & Log UFC/ ml \\
\hline \multirow{3}{*}{$\mathrm{A} 1$} & 1 & 630 & 630.000 & $63,0 \times 10^{4}$ & 5,799 \\
\hline & 2 & 690 & 690.000 & $69,0 \times 10^{4}$ & 5,838 \\
\hline & 3 & 650 & 650.000 & $65,0 \times 10^{4}$ & 5,812 \\
\hline \multirow{3}{*}{ A2 } & 1 & 480 & 480.000 & $48,0 \times 10^{4}$ & 5,681 \\
\hline & 2 & 540 & 540.000 & $54,0 \times 10^{4}$ & 5,732 \\
\hline & 3 & 500 & 500.000 & $50,0 \times 10^{4}$ & 5,698 \\
\hline \multirow{3}{*}{ A3 } & 1 & 660 & 660.000 & $66,0 \times 10^{4}$ & 5,819 \\
\hline & 2 & 570 & 570.000 & $57,0 \times 10^{4}$ & 5,755 \\
\hline & 3 & 680 & 680.000 & $68,0 \times 10^{4}$ & 5,832 \\
\hline
\end{tabular}

Tabela 23. Distribuição de células viáveis de $P$. aeruginosa recuperadas após contato com a superfície do poliuretano e polipropileno após 4 horas.

\begin{tabular}{|c|c|c|c|c|c|}
\hline Poliuretano & Repetições & UFC/ ml & $\begin{array}{c}\text { UFC/ml } \\
\text { x Fator Diluição } \\
(\times 1000)\end{array}$ & $\begin{array}{l}\text { Número } \\
\text { total }\end{array}$ & Log UFC/ ml \\
\hline \multirow{3}{*}{$\mathrm{A} 1$} & 1 & 1370 & 1.370 .000 & $137,0 \times 10^{4}$ & 6,136 \\
\hline & 2 & 1390 & 1.390 .000 & $139.0 \times 10^{4}$ & 6.143 \\
\hline & 3 & 1260 & 1.260 .000 & $126,0 \times 10^{4}$ & 6,100 \\
\hline \multirow{3}{*}{$\mathrm{A} 2$} & 1 & 1340 & 1.340 .000 & $134,0 \times 10^{4}$ & 6,127 \\
\hline & 2 & 1370 & 1.370 .000 & $137,0 \times 10^{4}$ & 6,136 \\
\hline & 3 & 1220 & 1.220 .000 & $122,0 \times 10^{4}$ & 6,086 \\
\hline \multirow{3}{*}{ A3 } & 1 & 1320 & 1.320 .000 & $132,0 \times 10^{4}$ & 6,120 \\
\hline & 2 & 1200 & 1.200 .000 & $120,0 \times 10^{4}$ & 6,079 \\
\hline & 3 & 1340 & 1.340 .000 & $134,0 \times 10^{4}$ & 6,127 \\
\hline Polipropileno & Repetições & UFC/ ml & $\begin{array}{c}\text { UFC/ml ml } \\
\text { x Fator Diluição } \\
(\times 1000)\end{array}$ & $\begin{array}{c}\text { Número } \\
\text { total }\end{array}$ & Log UFC/ ml \\
\hline \multirow{3}{*}{$\mathrm{A} 1$} & 1 & 1610 & 1.610 .000 & $161,0 \times 10^{4}$ & 6,206 \\
\hline & 2 & 1790 & 1.790 .000 & $179,0 \times 10^{4}$ & 6,252 \\
\hline & 3 & 1820 & 1.820 .000 & $182,0 \times 10^{4}$ & 6,260 \\
\hline \multirow{3}{*}{$\mathrm{A} 2$} & 1 & 1860 & 1.860 .000 & $186,0 \times 10^{4}$ & 6,269 \\
\hline & 2 & 1740 & 1.740 .000 & $174,0 \times 10^{4}$ & 6,240 \\
\hline & 3 & 1440 & 1.440 .000 & $144,0 \times 10^{4}$ & 6,158 \\
\hline \multirow{3}{*}{ A3 } & 1 & 1680 & 1.680 .000 & $168,0 \times 10^{4}$ & 6,225 \\
\hline & 2 & 1720 & 1.720 .000 & $172,0 \times 10^{4}$ & 6,235 \\
\hline & 3 & 1640 & 1.640 .000 & $164,0 \times 10^{4}$ & 6,214 \\
\hline
\end{tabular}


Tabela 24. Distribuição de células viáveis de $P$. aeruginosa recuperadas após contato com a superfície do poliuretano e polipropileno após 24 horas.

\begin{tabular}{|c|c|c|c|c|c|}
\hline Poliuretano & Repetições & UFC/ ml & 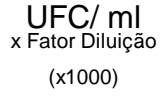 & $\begin{array}{l}\text { Número } \\
\text { total }\end{array}$ & Log UFC/ ml \\
\hline \multirow{3}{*}{$\mathrm{A} 1$} & 1 & 4040 & 4.040 .000 & $404,0 \times 10^{4}$ & 6,606 \\
\hline & 2 & 3880 & 3.880 .000 & $388,0 \times 10^{4}$ & 6,588 \\
\hline & 3 & 3900 & 3.900 .000 & $390,0 \times 10^{4}$ & 6,591 \\
\hline \multirow{3}{*}{$\mathrm{A} 2$} & 1 & 3960 & 3.960 .000 & $396,0 \times 10^{4}$ & 6,597 \\
\hline & 2 & 4100 & 4.100 .000 & $410,0 \times 10^{4}$ & 6,612 \\
\hline & 3 & 4280 & 4.280 .000 & $428,0 \times 10^{4}$ & 6,631 \\
\hline \multirow{3}{*}{ A3 } & 1 & 3840 & 3.840 .000 & $384,0 \times 10^{4}$ & 6,584 \\
\hline & 2 & 4320 & 4.320 .000 & $432,0 \times 10^{4}$ & 6,635 \\
\hline & 3 & 3700 & 3.700 .000 & $370,0 \times 10^{4}$ & 6,568 \\
\hline Polipropileno & Repetições & UFC/ ml & $\begin{array}{l}\text { UFC/ ml } \\
\text { x Fator Diluição } \\
(\times 1000)\end{array}$ & $\begin{array}{l}\text { Número } \\
\text { total }\end{array}$ & Log UFC/ ml \\
\hline \multirow{3}{*}{$\mathrm{A} 1$} & 1 & 5440 & 5.440 .000 & $544,0 \times 10^{4}$ & 6,735 \\
\hline & 2 & 6900 & 6.900 .000 & $690,0 \times 10^{4}$ & 6,838 \\
\hline & 3 & 6080 & 6.080 .000 & $608,0 \times 10^{4}$ & 6,783 \\
\hline \multirow{3}{*}{$\mathrm{A} 2$} & 1 & 5600 & 5.600 .000 & $560,0 \times 10^{4}$ & 6,748 \\
\hline & 2 & 6800 & 6.800 .000 & $680,0 \times 10^{4}$ & 6,832 \\
\hline & 3 & 5550 & 5.550 .000 & $555,0 \times 10^{4}$ & 6,744 \\
\hline \multirow{3}{*}{ A3 } & 1 & 6440 & 6.440 .000 & $644,0 \times 10^{4}$ & 6,808 \\
\hline & 2 & 5100 & 5.100 .000 & $510,0 \times 10^{4}$ & 6,707 \\
\hline & 3 & 4670 & 4.670 .000 & $467,0 \times 10^{4}$ & 6,669 \\
\hline
\end{tabular}

Tabela 25. Distribuição de células viáveis de $P$. aeruginosa recuperadas após contato com a superfície do poliuretano e polipropileno após 48 horas.

\begin{tabular}{|c|c|c|c|c|c|}
\hline Poliuretano & Repetições & UFC/ $\mathrm{ml}$ & $\begin{array}{c}\text { UFC/ml ml } \\
\text { x Fator Diluição } \\
(\times 1000)\end{array}$ & $\begin{array}{l}\text { Número } \\
\text { total }\end{array}$ & Log UFC/ ml \\
\hline A1 & $\begin{array}{l}1 \\
2 \\
3\end{array}$ & $\begin{array}{l}5840 \\
5040 \\
4960\end{array}$ & $\begin{array}{l}5.840 .000 \\
5.040 .000 \\
4.960 .000\end{array}$ & $\begin{array}{l}584,0 \times 10^{4} \\
504,0 \times 10^{4} \\
496,0 \times 10^{4}\end{array}$ & $\begin{array}{l}6,766 \\
6,702 \\
6,695\end{array}$ \\
\hline $\mathrm{A} 2$ & $\begin{array}{l}1 \\
2 \\
3\end{array}$ & $\begin{array}{l}4300 \\
4000 \\
5900\end{array}$ & $\begin{array}{l}4.300 .000 \\
4.000 .000 \\
5.900 .000\end{array}$ & $\begin{array}{l}430,0 \times 10^{4} \\
400,0 \times 10^{4} \\
590,0 \times 10^{4}\end{array}$ & $\begin{array}{l}6,633 \\
6,602 \\
6,770\end{array}$ \\
\hline A3 & $\begin{array}{l}1 \\
2 \\
3\end{array}$ & $\begin{array}{l}4700 \\
5160 \\
4800\end{array}$ & $\begin{array}{l}4.700 .000 \\
5.160 .000 \\
4.800 .000\end{array}$ & $\begin{array}{l}470,0 \times 10^{4} \\
516,0 \times 10^{4} \\
480,0 \times 10^{4}\end{array}$ & $\begin{array}{l}6,672 \\
6,712 \\
6,681\end{array}$ \\
\hline Polipropileno & Repetições & UFC/ ml & $\begin{array}{c}\text { UFC/m } \\
\text { x Fator Diluição } \\
(\times 1000)\end{array}$ & $\begin{array}{c}\text { Número } \\
\text { total }\end{array}$ & Log UFC/ ml \\
\hline A1 & $\begin{array}{l}1 \\
2 \\
3\end{array}$ & $\begin{array}{l}6240 \\
5680 \\
5720\end{array}$ & $\begin{array}{l}6.240 .000 \\
5.680 .000 \\
5.720 .000\end{array}$ & $\begin{array}{l}624,0 \times 10^{4} \\
568,0 \times 10^{4} \\
572,0 \times 10^{4}\end{array}$ & $\begin{array}{l}6,795 \\
6,754 \\
6,757\end{array}$ \\
\hline $\mathrm{A} 2$ & $\begin{array}{l}1 \\
2 \\
3\end{array}$ & $\begin{array}{l}7000 \\
6400 \\
6600\end{array}$ & $\begin{array}{l}7.000 .000 \\
6.400 .000 \\
6.600 .000\end{array}$ & $\begin{array}{l}700,0 \times 10^{4} \\
640,0 \times 10^{4} \\
660,0 \times 10^{4}\end{array}$ & $\begin{array}{l}6,845 \\
6,806 \\
6,819\end{array}$ \\
\hline A3 & $\begin{array}{l}1 \\
2 \\
3\end{array}$ & $\begin{array}{l}5120 \\
6000 \\
5330\end{array}$ & $\begin{array}{l}5.120 .000 \\
6.000 .000 \\
5.330 .000\end{array}$ & $\begin{array}{l}512,0 \times 10^{4} \\
600,0 \times 10^{4} \\
533,0 \times 10^{4}\end{array}$ & $\begin{array}{l}6,709 \\
6,778 \\
6,726\end{array}$ \\
\hline
\end{tabular}


Tabela 26. Distribuição de células viáveis de $P$. aeruginosa recuperadas após contato com a superfície do poliuretano e polipropileno após 72 horas.

\begin{tabular}{|c|c|c|c|c|c|}
\hline Poliuretano & Repetições & UFC/ ml & $\begin{array}{c}\mathrm{UFC/ml} \\
\times \begin{array}{c}\mathrm{UFator} \text { Diluição } \\
(\times 1000)\end{array}\end{array}$ & $\begin{array}{c}\text { Número } \\
\text { total }\end{array}$ & Log UFC/ ml \\
\hline \multirow{3}{*}{ A1 } & 1 & 5200 & 5.200 .000 & $520,0 \times 10^{4}$ & 6,716 \\
\hline & 2 & 6240 & 6.240 .000 & $624,0 \times 10^{4}$ & 6,795 \\
\hline & 3 & 5000 & 5.000 .000 & $500,0 \times 10^{4}$ & 6,698 \\
\hline \multirow{3}{*}{ A2 } & 1 & 5700 & 5.700 .000 & $570,0 \times 10^{4}$ & 6,755 \\
\hline & 2 & 6480 & 6.480 .000 & $648,0 \times 10^{4}$ & 6,811 \\
\hline & 3 & 6100 & 6.100 .000 & $610,0 \times 10^{4}$ & 6,785 \\
\hline \multirow{3}{*}{ A3 } & 1 & 5750 & 5.750 .000 & $575,0 \times 10^{4}$ & 6,759 \\
\hline & 2 & 5800 & 5.800 .000 & $580,0 \times 10^{4}$ & 6,763 \\
\hline & 3 & 6690 & 6.690 .000 & $669,0 \times 10^{4}$ & 6,825 \\
\hline Polipropileno & Repetições & UFC/ ml & $\begin{array}{c}\text { XFC/ ml } \\
\text { x Fator Diluição } \\
(\times 1000)\end{array}$ & $\begin{array}{l}\text { Número } \\
\text { total }\end{array}$ & Log UFC/ ml \\
\hline \multirow{3}{*}{ A1 } & 1 & 7800 & 7.800 .000 & $780,0 \times 10^{4}$ & 6,892 \\
\hline & 2 & 6950 & 6.950 .000 & $695,0 \times 10^{4}$ & 6,841 \\
\hline & 3 & 7400 & 7.400 .000 & $740,0 \times 10^{4}$ & 6,869 \\
\hline \multirow{3}{*}{ A2 } & 1 & 6000 & 6.000 .000 & $600,0 \times 10^{4}$ & 6,778 \\
\hline & 2 & 7600 & 7.600 .000 & $760,0 \times 10^{4}$ & 6,880 \\
\hline & 3 & 6200 & 6.200 .000 & $620,0 \times 10^{4}$ & 6,792 \\
\hline \multirow{3}{*}{ A3 } & 1 & 5800 & 5.800 .000 & $580,0 \times 10^{4}$ & 6,763 \\
\hline & 2 & 6400 & 6.400 .000 & $640,0 \times 10^{4}$ & 6,806 \\
\hline & 3 & 5560 & 5.560 .000 & $556,0 \times 10^{4}$ & 6,745 \\
\hline
\end{tabular}

Tabela 27. Distribuição de células viáveis de $P$. aeruginosa recuperadas após contato com a superfície do poliuretano e polipropileno após 120 horas.

\begin{tabular}{|c|c|c|c|c|c|}
\hline Poliuretano & Repetições & $\mathrm{UFC} / \mathrm{ml}$ & $\begin{array}{l}\mathrm{UFC} / \mathrm{ml} \\
\text { x Fator Diluição } \\
\text { (x1000) }\end{array}$ & $\begin{array}{c}\text { Número } \\
\text { total }\end{array}$ & Log UFC/ ml \\
\hline \multirow{3}{*}{ A } & 1 & 3080 & 3.080 .000 & $308,0 \times 10^{4}$ & 6,488 \\
\hline & 2 & 3500 & 3.500 .000 & $350,0 \times 10^{4}$ & 6,544 \\
\hline & 3 & 3700 & 3.700 .000 & $370,0 \times 10^{4}$ & 6,568 \\
\hline \multirow{3}{*}{ B } & 1 & 3880 & 3.880 .000 & $388,0 \times 10^{4}$ & 6,588 \\
\hline & 2 & 3000 & 3.000 .000 & $300,0 \times 10^{4}$ & 6,477 \\
\hline & 3 & 3300 & 3.300 .000 & $330,0 \times 10^{4}$ & 6,518 \\
\hline \multirow{3}{*}{ C } & 1 & 3800 & 3.800 .000 & $380,0 \times 10^{4}$ & 6,579 \\
\hline & 2 & 3200 & 3.200 .000 & $320,0 \times 10^{4}$ & 6,505 \\
\hline & 3 & 2920 & 2.920 .000 & $292,0 \times 10^{4}$ & 6,465 \\
\hline Polipropileno & Repetições & UFC/ ml & $\begin{array}{l}\text { UFC/ ml } \\
\text { x Fator Diluição } \\
\text { (x1000) }\end{array}$ & $\begin{array}{l}\text { Número } \\
\text { total }\end{array}$ & Log UFC/ ml \\
\hline \multirow{3}{*}{ A } & 1 & 3100 & 3.100 .000 & $310,0 \times 10^{4}$ & 6,491 \\
\hline & 2 & 2700 & 2.700 .000 & $270,0 \times 10^{4}$ & 6,431 \\
\hline & 3 & 2400 & 2.400 .000 & $240,0 \times 10^{4}$ & 6,380 \\
\hline \multirow{3}{*}{ B } & 1 & 4120 & 4.120 .000 & $412,0 \times 10^{4}$ & 6,614 \\
\hline & 2 & 4440 & 4.440 .000 & $444,0 \times 10^{4}$ & 6,647 \\
\hline & 3 & 3640 & 3.640 .000 & $364,0 \times 10^{4}$ & 6,561 \\
\hline \multirow{3}{*}{ C } & 1 & 4900 & 4.900 .000 & $490,0 \times 10^{4}$ & 6,690 \\
\hline & 2 & 4200 & 4.200 .000 & $420,0 \times 10^{4}$ & 6,623 \\
\hline & 3 & 4700 & 4.700 .000 & $470,0 \times 10^{4}$ & 6,672 \\
\hline
\end{tabular}

